Prepared in Cooperation with the City of Aurora, Colorado, Utilities Department

\title{
Selenium and Other Elements in Water and Adjacent Rock and Sediment of Toll Gate Creek, Aurora, Arapahoe County, Colorado, December 2003 through March 2004
}

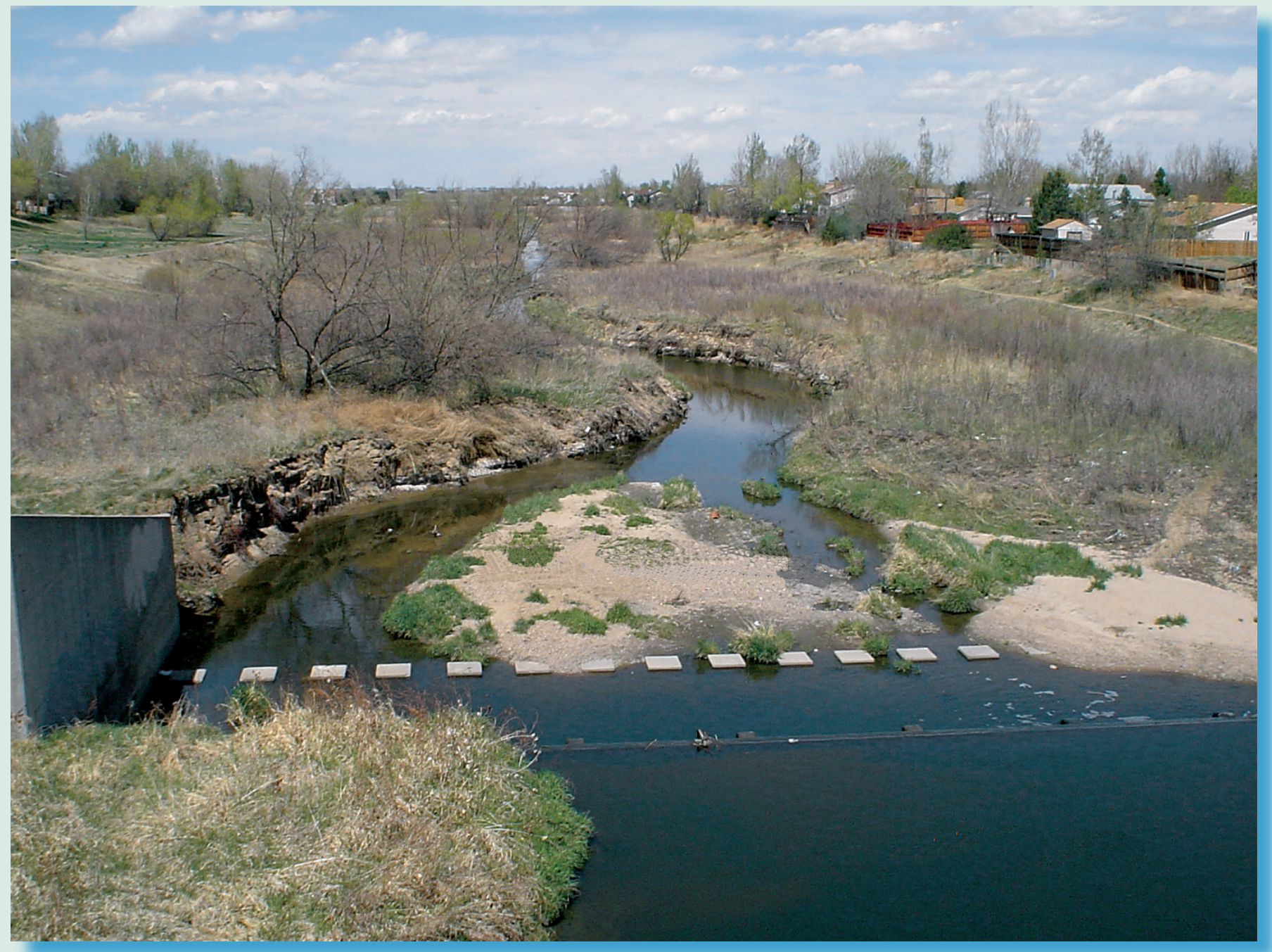

Scientific Investigations Report 2007-5018 


\section{Selenium and Other Elements in Water and Adjacent Rock and Sediment of Toll Gate Creek, Aurora, Arapahoe County, Colorado, December 2003 through March 2004}

By J.R. Herring and Katherine Walton-Day

Prepared in Cooperation with the City of Aurora, Colorado, Utilities Department

Scientific Investigations Report 2007-5018 


\section{U.S. Department of the Interior DIRK KEMPTHORNE, Secretary}

\section{U.S. Geological Survey \\ Mark D. Myers, Director}

\section{U.S. Geological Survey, Reston, Virginia: 2007}

For product and ordering information:

World Wide Web: http://www.usgs.gov/pubprod

Telephone: 1-888-ASK-USGS

For more information on the USGS — the Federal source for science about the Earth, its natural and living resources, natural hazards, and the environment:

World Wide Web: http://www.usgs.gov

Telephone: 1-888-ASK-USGS

Any use of trade, product, or firm names is for descriptive purposes only and does not imply endorsement by the U.S. Government.

Although this report is in the public domain, permission must be secured from the individual copyright owners to reproduce any copyrighted materials contained within this report.

Suggested citation:

Herring, J.R., and Walton-Day, K., 2007, Selenium and other elements in water and adjacent rock and sediment of Toll Gate Creek, Aurora, Araphahoe County, Colorado, December 2003 through March 2004, 58 p. 


\section{Contents}

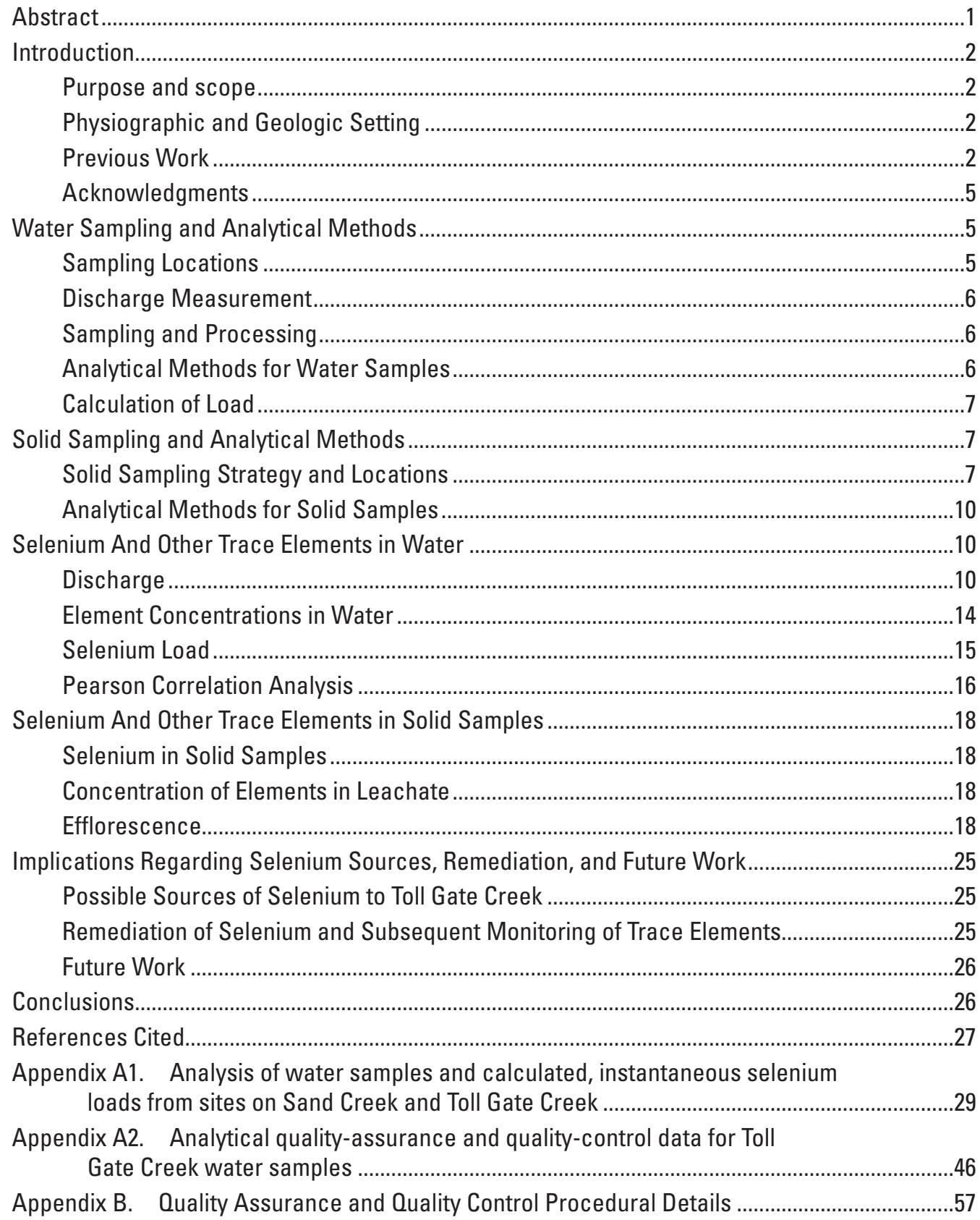

\section{Figures}

1. Location of Toll Gate Creek drainage area, water and solid sampling locations, and locations of historic data collection ..........................................................................

2. View of typical graded slope along bank of Toll Gate Creek .............................................. 
3. View of streambank channel sample WTGS/R-1.4A directly north of the Mississippi Street overpass.

4. Discharge profile along Toll Gate Creek for December 2003 and March 2004 sampling events

5. Selenium concentration profile along Toll Gate Creek for December 2003 and March 2004 sampling events

6. Selenium load profile along Toll Gate Creek for December 2003 and March 2004 sampling events

7. Selenium load and discharge and linear regressions for December 2003 and March 2004 sampling events .16

8. View of efflorescence zone along West Toll Gate Creek directly north of Mississippi Street overpass.... 24

9. View of wetland and golf course located on East Toll Gate Creek .25

\section{Tables}

1. Historical Data on Dissolved Selenium Concentrations and Loads in Toll Gate Creek and comparison with Sand Creek..........................................................

2. Location and description of solid sampling locations, Toll Gate Creek ..............................9

3. Energy Dispersive X-Ray Fluorescence (EDXRF) analysis of rock and unconsolidated sediment samples adjacent to Toll Gate Creek

4. Correlation coefficients among elements in Toll Gate Creek water samples ..................17

5. Composition of water leachate and digestions of various rock and unconsolidated rock samples, Toll Gate Creek

A1. Analysis of water samples and calculated, instantaneous selenium loads from sites on Sand Creek and Toll Gate Creek.

A2. Analytical quality-assurance and quality-control data for Toll Gate

Creek water samples 


\section{Conversion Factors}

SI to Inch/Pound

\begin{tabular}{|c|c|c|}
\hline Multiply & By & To obtain \\
\hline \multicolumn{3}{|c|}{ Length } \\
\hline meter $(\mathrm{m})$ & 3.281 & foot $(\mathrm{ft})$ \\
\hline centimeter $(\mathrm{cm})$ & 0.3937 & inch \\
\hline kilometer $(\mathrm{km})$ & 0.6214 & mile (mi) \\
\hline \multicolumn{3}{|c|}{ Volume } \\
\hline liter $(\mathrm{L})$ & 0.2642 & gallon (gal) \\
\hline cubic meter $\left(\mathrm{m}^{3}\right)$ & 264.2 & gallon (gal) \\
\hline cubic meter $\left(\mathrm{m}^{3}\right)$ & 35.31 & cubic foot $\left(\mathrm{ft}^{3}\right)$ \\
\hline \multicolumn{3}{|c|}{ Flow rate } \\
\hline cubic meter per second $\left(\mathrm{m}^{3} / \mathrm{s}\right)$ & 35.31 & cubic feet per second $\left(\mathrm{ft}^{3} / \mathrm{s}\right)$ \\
\hline liter per second $(\mathrm{L} / \mathrm{s})$ & 15.85 & gallon per minute (gal/min) \\
\hline cubic meter per day $\left(\mathrm{m}^{3} / \mathrm{d}\right)$ & 264.2 & gallon per day (gal/d) \\
\hline \multicolumn{3}{|c|}{ Mass } \\
\hline gram $(\mathrm{g})$ & 0.03527 & ounce \\
\hline kilogram (kg) & 2.205 & pound, avoirdupois (lb) \\
\hline
\end{tabular}

Temperature in degrees Celsius $\left({ }^{\circ} \mathrm{C}\right)$ may be converted to degrees Fahrenheit $\left({ }^{\circ} \mathrm{F}\right)$ as follows:

$$
{ }^{\circ} \mathrm{F}=\left(1.8 \times^{\circ} \mathrm{C}\right)+32
$$

Temperature in degrees Fahrenheit $\left({ }^{\circ} \mathrm{F}\right)$ may be converted to degrees Celsius $\left({ }^{\circ} \mathrm{C}\right)$ as follows:

$$
{ }^{\circ} \mathrm{C}=\left({ }^{\circ} \mathrm{F}-32\right) / 1.8
$$

Horizontal coordinate information is referenced to the North American Datum of 1983 (NAD 83)

Specific conductance is given in microsiemens per centimeter at 25 degrees Celsius $\left(\mu \mathrm{S} / \mathrm{cm}\right.$ at $\left.25^{\circ} \mathrm{C}\right)$.

Concentrations of chemical constituents in water are given either in milligrams per liter (mg/L) or micrograms per liter ( $\mu \mathrm{g} / \mathrm{L})$. 


\section{Additional Abbreviations}

\begin{tabular}{|c|c|}
\hline DIW & Deionized water \\
\hline EDXRF & Energy dispersive $\mathrm{X}$-ray fluorescence \\
\hline EPA & U.S. Environmental Protection Agency \\
\hline ETGC & East Toll Gate Creek \\
\hline$g / d$ & gram per day \\
\hline $\mathrm{HNO}_{3}$ & Ultrex nitric acid \\
\hline ICP-MS & inductively coupled plasma mass spectrometry \\
\hline kV & kilovolt \\
\hline LLD & lower limit of detection \\
\hline L/s & liter per second \\
\hline $\mathrm{mA}$ & milliampere \\
\hline MCL & maximum contaminant level \\
\hline $\mathrm{mg} / \mathrm{Kg}$ & milligram per kilogram \\
\hline $\mathrm{mm}$ & millimeter \\
\hline $\mathrm{mL}$ & milliliter \\
\hline $\mathrm{M} \Omega$ & meg-ohm \\
\hline $\mathrm{mS} / \mathrm{cm}$ & millisiemens per centimeter at 25 degrees Celsius \\
\hline NAWQA & National Water Quality Assessment \\
\hline NGD & National Geochemical Database \\
\hline NIST & National Institute of Standards and Technology \\
\hline ORP & oxidation-reduction potential \\
\hline ppm & part per million \\
\hline Se & selenium \\
\hline TDS & total dissolved solids \\
\hline TGC & Toll Gate Creek \\
\hline TMDL & total maximum daily load \\
\hline$\mu \mathrm{m}$ & micrometer \\
\hline USGS & U.S. Geological Survey \\
\hline WTGC & West Toll Gate Creek \\
\hline RD & X-ray diffraction analyses \\
\hline
\end{tabular}




\title{
Selenium and Other Elements in Water and Adjacent Rock and Sediment of Toll Gate Creek, Aurora, Arapahoe County, Colorado, December 2003 through March 2004
}

\author{
by J.R. Herring and Katherine Walton-Day
}

\section{Abstract}

Streamwater and solid samples (rock, unconsolidated sediment, stream sediment, and efflorescent material) in the Toll Gate Creek watershed, Colorado, were collected and analyzed for major and trace elements to determine trace-element concentrations and stream loads from December 2003 through March 2004, a period of seasonally low flow. Special emphasis was given to selenium ( $\mathrm{Se}$ ) concentrations because historic Se concentrations exceeded current (2004) stream standards. The goal of the project was to assess the distribution of Se concentration and loads in Toll Gate Creek and to determine the potential for rock and unconsolidated sediment in the basin to be sources of Se to the streamwater.

Streamwater samples and discharge measurements were collected during December 2003 and March 2004 along Toll Gate Creek and its two primary tributaries - West Toll Gate Creek and East Toll Gate Creek. During both sampling periods, discharge ranged from 2.5 liters per second to 138 liters per second in the watershed. Discharge was greater in March 2004 than December 2003, but both periods represent low flow in Toll Gate Creek, and results of this study should not be extended to periods of higher flow. Discharge decreased moving downstream in East Toll Gate Creek but increased moving downstream along West Toll Gate Creek and the main stem of Toll Gate Creek, indicating that these two streams gain flow from ground water. Se concentrations in streamwater samples ranged from 7 to 70 micrograms per liter, were elevated in the upstream-most samples, and were greater than the State stream standard of 4.6 micrograms per liter. Se loads ranged from 6 grams per day to 250 grams per day, decreased in a downstream direction along East Toll Gate Creek, and increased in a downstream direction along West Toll Gate Creek and Toll Gate Creek. The largest Se-load increases occurred between two sampling locations on West Toll Gate Creek during both sampling periods and between the two sampling locations on the main stem of Toll Gate Creek during the December 2003 sampling. These load increases may indicate that sources of Se exist between these two locations; however, Se loading along West Toll Gate Creek and Toll Gate Creek primarily was characterized by gradual downstream increases in load.
Linear regressions between Se load and discharge for both sampling periods had large, significant values of $\mathrm{r}^{2}\left(\mathrm{r}^{2}>0.96\right.$, $\mathrm{p}<0.0001$ ) because increases in Se load (per unit of flow increase) were generally constant. This relation is evidence for a constant addition of water having a relatively constant Se concentration over much of the length of Toll Gate Creek, a result which is consistent with a ground-water source for the Se loads.

Rock outcroppings along the stream were highly weathered, and Se concentrations in rock and other solid samples ranged from below detection (1 part per million) to 25 parts per million. One sample of efflorescence (a surface encrustation produced by evaporation) had the greatest selenium concentration of all solid samples, was composed of thenardite (sodium sulfate), gypsum (calcium sulfate) and minor halite (sodium chloride), and released all of its Se during a 30minute water-leaching procedure. Calculations indicate there was an insufficient amount of this material present throughout the watershed to account for the observed Se load in the stream. However, this material likely indicates zones of ground-water discharge that contain Se.

This report did not identify an unequivocal source of Se in Toll Gate Creek. However, multiple lines of evidence indicate that ground-water discharge supplies Se to Toll Gate Creek: (1) the occurrence of elevated Se concentrations in the stream throughout the watershed and in the headwater regions, upstream from industrial sources; (2) the progressive increase in Se loads moving downstream, which indicates a continuous input of Se along the stream rather than input from point sources; (3) the occurrence of efflorescence deposits in several locations along the stream channel that contain elevated concentrations of readily soluble Se and probably represent ground-water discharge zones; and (4) the occurrence of rock types within the Toll Gate Creek watershed that may contain elevated concentrations of Se (ash layers and lignite deposits). Ground water likely acquires the Se through water-rock interaction with the aquifers underlying Toll Gate Creek. Shallow ground water containing soluble Se discharges to Toll Gate Creek. 


\section{Introduction}

In response to a request by the City of Aurora, Colorado, the U.S. Geological Survey (USGS) began a series of geologic and water-quality studies from December 2003 through March 2004 to study water quality and nearby rock and unconsolidated sediment of Toll Gate Creek (TGC) (fig. 1). The request arose because of recent concerns about elevated selenium (Se) concentrations in TGC. Historical data indicate that elevated Se concentrations occur in surface water in East Toll Gate Creek (ETGC), West Toll Gate Creek (WTGC), and TGC (Brown and Caldwell and Chadwick Ecological Consultants, 2003) which are tributary to Sand Creek (fig. 1). Se concentrations occasionally exceed the national primary drinking water standard Maximum Contaminant Level (MCL) of 50 micrograms per liter ( $\mu \mathrm{g} / \mathrm{L})$, established by the U.S. Environmental Protection Agency (EPA) (U.S. Environmental Protection Agency, 2002) and greatly exceed the State stream standard $4.6 \mu \mathrm{g} / \mathrm{L}$ (Colorado Department of Public Health and Environment, 2005). Neither Sand Creek nor TGC are used for drinking-water supply. Sand Creek, TGC, WTGC, and ETGC are on the most recent 303(d) list for Se. Therefore, a Total Maximum Daily Load (TMDL) may need to be developed. The City of Aurora is currently (2007) working on development of an alternative standard based on the assumption that the source of Se is naturally occurring and that remediation of the Se will result in widespread social or environmental impacts. This study was conducted to assess whether elevated Se concentrations in TGC (tributary to Sand Creek) result from the natural interaction of rock solids and water within the drainage area. The information provided will help with formulation of a new standard for Sand Creek.

\section{Purpose and scope}

The purpose of this report is to describe and interpret results from surveys of streamwater quality and discharge and geochemistry of solid samples collected from the TGC watershed from December 2003 to March 2004. Mass loads for Se were calculated from streamflow and water-quality data collected at as many as 13 stream sites. Twenty-one rock, unconsolidated sediment, and stream-sediment samples, and samples of efflorescent salts were collected from areas within and adjacent to TGC and were retrieved from archived drillcore samples from wells drilled within the watershed. Water and solid samples and some digestions of solid samples were analyzed for concentrations of Se and other trace and major elements. This report provides analysis and interpretation of major and trace-element concentrations and Se loads in the streamwater and of major and trace-element concentrations in rocks and unconsolidated sediment that might be contributing Se or other trace elements to the streamwater.

\section{Physiographic and Geologic Setting}

Land use is varied within the drainage basin of TGC. The stream has its headwaters in rolling prairie, urbanized within the past 15 years with residential housing, and flows northwest toward the confluence with Sand Creek (fig. 1). ETGC flows through the southwest corner of Buckley Air National Guard Base but was dry upstream from ETGS-2 during the December 2003 and March 2004 sampling events. WTGC is diverted around the west side of Quincy Reservoir and has no direct interaction with the reservoir water. In addition, WTGC can accept water from the overflow spillway of Cherry Creek Reservoir, but this is not known to have happened within the last decade. In its lower reaches, TGC flows next to the Fitzsimmons Army Medical Center. The stream is perennial sustaining base flow throughout the year and has sharp peaks in flow in response to storm events (C.R. Bossong, U.S. Geological Survey, oral commun., 2007).

Geology of the TGC watershed is characterized by Quaternary unconsolidated surficial materials as much as 10 meters (m) thick (Robson, 1996) overlying the Cretaceous to early Tertiary-aged Denver Formation bedrock. Surficial materials include alluvial, colluvial, and eolian deposits. The alluvial deposits consist of gravel, sand, silt, and clay. Colluvial deposits consist of the same components and commonly are derived from the underlying bedrock. Eolian deposits consist of fine- to medium-grained windblown sand. The bedrock underlying the unconsolidated sediments is the Denver Formation, which consists of weakly consolidated mudstone and occasional beds of consolidated siltstone or sandstone, localized seams of low-rank coal, and volcanic ash layers. Volcanic ash can contain Se; however, there is no documentation of Se in the Denver Formation volcanic-ash layers.

\section{Previous Work}

A report prepared for the annual Selenium Stakeholders Meeting, April 2003, summarized Se concentrations, loads, and other water-quality parameters for various locations on TGC, nearby sites, Sand Creek, and the South Platte River for various dates 1995 to 2002 (Brown and Caldwell and Chadwick Ecological Consultants, 2003). These data had precision of $+/-7$ percent based on analysis of three replicate sample pairs, but contained no assessment of bias. The Se concentration and streamflow data from four locations sampled during 2002 were summarized (table 1) to depict Se loads that originated in TGC and contributed to Sand Creek and eventually the South Platte River. The monthly data collected from January to November 2002 enabled comparison of Se loads between WTGC and ETGC and between TGC and Sand Creek (SWA, fig.1). These data indicate the following general conclusions. ETGC Se loads ranged from 1.0 to 14 percent and averaged 8 percent of the Se load in WTGC (average of 6 values); the Se load in TGC continued to increase and approximately doubled by station TG-1, downstream from 


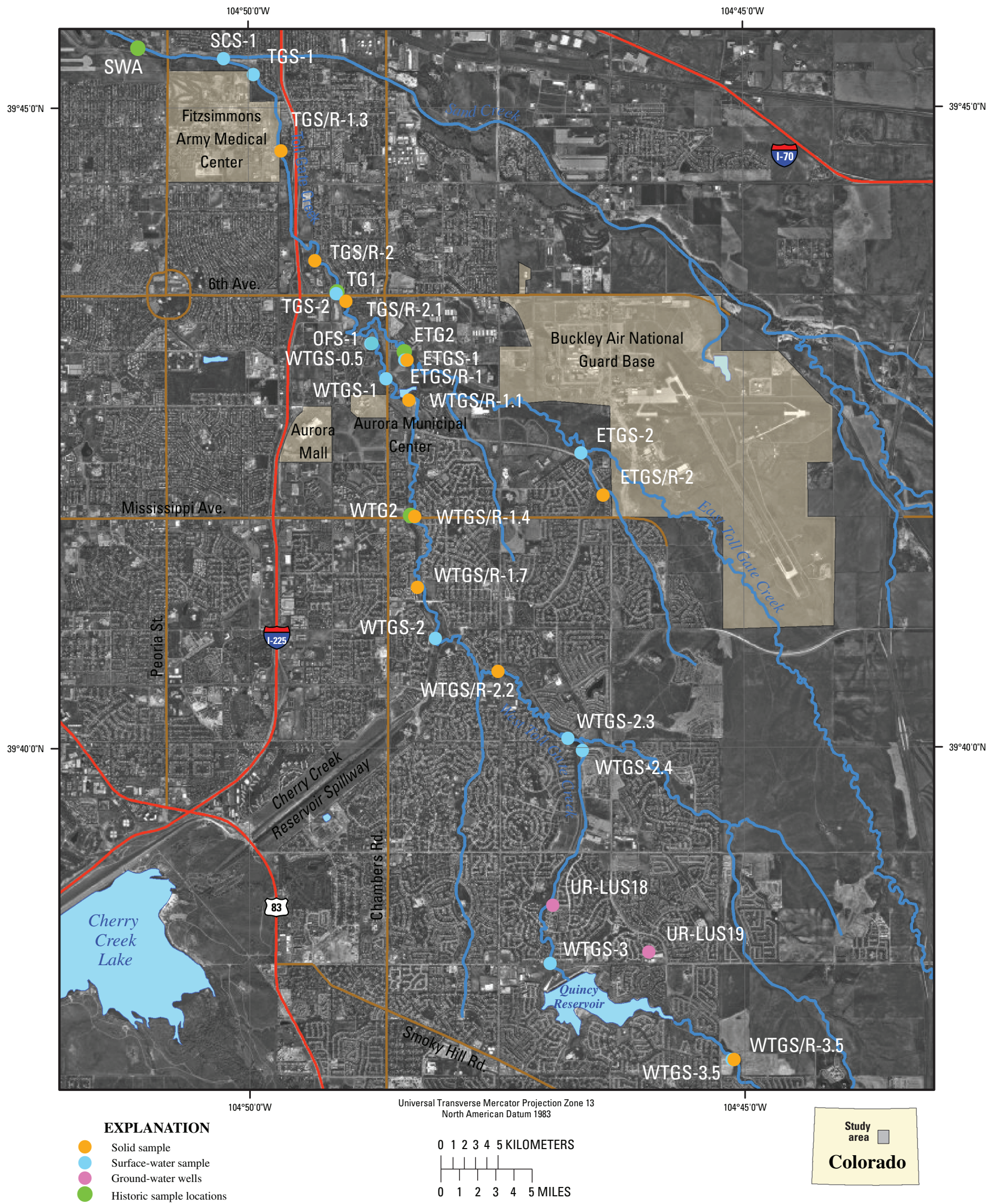

Figure 1. Location of Toll Gate Creek drainage area, water and solid sampling locations, and locations of historic data collection. 
Table 1. Historical Data on Dissolved Selenium Concentrations and Loads in Toll Gate Creek and comparison with Sand Creek.

[Data from Brown and Caldwell and Chadwick Ecological Consultants, 2003; date in month/day/year; $\mu \mathrm{g} / \mathrm{L}$, micrograms per liter, L/s, liters per second; g/d, grams per day; - indicates no data ; * indicates value eliminated because of inconsistency in reported discharge; WTG-2, West Toll Gate Creek station 2; ETG-2, East Toll Gate Creek station 2; TG-1, Toll Gate Creek station 1; SWA, Sand Creek sampling location]

\begin{tabular}{|c|c|c|c|c|c|c|c|c|c|c|c|c|}
\hline Component/Location & $\begin{array}{l}\text { Average, } \\
\text { all dates }\end{array}$ & $1 / 9 / 2002$ & 2/6/2002 & $3 / 6 / 2002$ & $4 / 3 / 2002$ & $5 / 1 / 2002$ & $6 / 5 / 2002$ & 7/3/2002 & $8 / 6 / 2002$ & 9/4/2002 & $10 / 2 / 2002$ & $11 / 6 / 2002$ \\
\hline \multicolumn{13}{|c|}{ Dissolved Se, $\mu \mathrm{g} / \mathrm{L}$} \\
\hline WTG-2-at Chambers & 13 & 22 & 22 & 9 & 14 & 11 & 5 & 12 & 10 & 19 & 2 & 15 \\
\hline ETG-2-at Chambers & 7 & 13 & 13 & 10 & 12 & 4 & 5 & 2 & 0.5 & - & 1 & - \\
\hline TG-1-at 6th Ave. & 14 & 25 & 26 & 12 & 18 & 15 & 5 & 11 & 5 & 16 & 2 & 16 \\
\hline SWA-Sand Ck. At Peoria & 12 & 21 & 19 & 10 & 13 & 9 & 6 & 8 & 10 & 14 & 4 & 13 \\
\hline \multicolumn{13}{|c|}{ Discharge, L/s } \\
\hline WTG-2-at Chambers & 113 & 33 & 45 & 253 & 65 & - & 465 & 9 & 20 & 3 & 220 & 18 \\
\hline ETG-2-at Chambers & 12 & 5 & 7 & 33 & 1 & - & 17 & 0 & 0 & 0 & 55 & 0 \\
\hline TG-1-at 6th Ave. & 186 & 65 & 103 & 301 & 102 & - & 594 & 66 & 91 & 239 & 458 & 40 \\
\hline SWA-Sand Ck. At Peoria & 369 & 209 & 200 & 578 & 525 & - & 752 & 86 & 133 & $*$ & 740 & 101 \\
\hline \multicolumn{13}{|c|}{ Load, g/d } \\
\hline WTG-2-at Chambers & 72 & 62.7 & 85.5 & 197 & 78.6 & - & 201 & 9.3 & 17.3 & 4.92 & 38.0 & 23.3 \\
\hline ETG-2-at Chambers & 9 & 5.6 & 7.8 & 28.5 & 1.0 & - & 7.3 & - & - & - & 4.8 & - \\
\hline TG-1-at 6th Ave. & 167 & 140 & 231 & 312 & 159 & - & 257 & 62.7 & 39.3 & 330 & 79.1 & 55.2 \\
\hline SWA-Sand Ck. At Peoria & 273 & 379 & 328 & 500 & 590 & - & 390 & 59.4 & 115 & $*$ & 256 & 113 \\
\hline $\begin{array}{l}\text { Average percent load ETGC } \\
\text { compared to WTGC }\end{array}$ & 8 & 9 & 9 & 14 & 1 & - & 4 & - & - & - & 13 & - \\
\hline $\begin{array}{l}\text { Average percentage of selenium load } \\
\text { of TGC compared to combined } \\
\text { load with Sand Creek }\end{array}$ & 53 & 37 & 70 & 62 & 27 & - & 66 & 105 & 34 & - & 31 & 49 \\
\hline
\end{tabular}


the confluence of ETGC and WTGC and upstream from the confluence with Sand Creek (table 1). The main stem of TGC (as estimated at TG-1) contributed an average of 53 percent (9 values), albeit with high scatter, of the combined Se load of TGC and Sand Creek (as estimated at station SWA, downstream from the confluence of Sand Creek and TGC (table 1). For the combined east and west reaches of TGC at $6^{\text {th }}$ Avenue, there was no coherent relation of load versus discharge. These historical data indicate that: elevated Se concentrations have existed in TGC since at least 2002; WTGC carried a greater Se load than ETGC; and the Se load of TGC accounted for approximately one-half of the load in Sand Creek downstream from the confluence with TGC.

Brown and Chadwick and Caldwell Ecological Associates (2003) also provided some measurements of Se in the bottom sediments of TGC that were analyzed in 2001 and 2002. For the 2002 data, the analyte was listed as "total Se (3050)" which presumably refers to EPA analytical method $3050 \mathrm{~B}$ which entails acid digestion of sediments, sludges, and soils with analysis of Se by graphite furnace atomic adsorption spectrometry, or inductively coupled plasma-mass spectrometry (U.S. Environmental Protection Agency, 1996; U.S. Environmental Protection Agency, variously dated). However, in Brown and Chadwick and Caldwell Ecological Associates (2003), the analytical method is not specified, and no qualityassurance/quality-control data were provided. The sediment Se concentrations mostly were less than 0.5 milligram per kilogram $(\mathrm{mg} / \mathrm{Kg}$ or parts per million (ppm)). However, Se concentrations of 1.8 and $6.2 \mathrm{mg} / \mathrm{Kg}$ were reported for WTGC at Chambers Road and ETGC at Chambers Road, respectively.

This study focuses on assessing Se concentrations and loads in TGC and on assessing Se concentration in geologic material near TGC. Analysis of solids and water focused primarily on Se, but the analytical techniques that were used also provide concentrations of several other trace elements and major elements. The goal of the study was to assess the distribution of Se concentration and loads in streamwater and to determine the potential for rock and unconsolidated sediment in TGC to contribute Se to streamwater.

\section{Acknowledgments}

Rhonda Driscoll provided assistance in samples preparation and X-ray diffraction analysis. Dave Siems and Tammy Hannah are acknowledged for Energy Dispersive X-Ray Fluorescence (EDXRF) analysis of the solid samples. Janel Servis provided field assistance, and Paul Lamothe furnished timely analysis of water samples. Suzanne Paschke and Kip Bossong kindly provided reviews of the report. Carma San Juan and John Horton assisted with preparation of figures.

\section{Water Sampling and Analytical Methods}

Water samples and discharge measurements were collected in the TGC watershed at 10 sites during December 2003 and 13 sites during March 2004. Samples were analyzed to determine concentrations of Se, major elements, and other trace elements. A few whole-water samples were collected and digested to help assess the contribution of suspended sediment to element loading in the TGC watershed. Se loads were constructed as the product of Se concentration and discharge.

\section{Sampling Locations}

Water samples were collected and discharge measurements were made December 16 and 17, 2003 and March 2, 2004. Water-sampling sites on TGC, WTGC, and ETGC were designated by alphanumeric characters where the initial abbreviation represents each stream or location name (Sand Creek stream, SCS-; Toll Gate Creek stream, TGS-; West Toll Gate Creek stream, WTGS-; East Toll Gate Creek stream, ETGS-; outfall sample, OFS-) and the numeric designations increased moving upstream along each stream. The December 2003 sampling effort included sampling 10 sites on December 16 , and resampling all 10 sites the following day to assess daily variability in Se concentration. In addition, sequential replicates were collected at three sites on December 16, 2003 (SCS-1, TGS-1, WTGS-2) and one site on December 17, 2003 (WTGS-3) to assess short-term environmental variability. All the same sites were sampled during the December 2003 and March 2004 events except that during March 2004 one new site was added on WTGC upstream from Quincy Reservoir to examine Se concentrations near the headwaters (fig. 1; table A1 in Appendix A at the back of the report). Two sites were added between WTGS-2 and WTGS-3 to bracket inflow from a pond located along that reach (fig. 1, table A1). The farthest downstream sample site on TGC (TGS-1, fig. 1) was a few hundred meters upstream from the confluence of TGC and Sand Creek. A site was sampled on Sand Creek (SCS1), directly upstream from the TGC confluence, to assess the relative contribution of TGC flow and loads to Sand Creek. In TGC, the farthest upstream location in the December sampling was a site on WTGC approximately 0.5 kilometer $(\mathrm{km})$ downstream from Quincy Reservoir (WTGS-3, fig. 1). In March 2004, an additional sample was collected upstream from Quincy Reservoir (WTGS-3.5, fig. 1). There was no flow upstream from ETGS-2 during both sampling events. These 13 sample sites in the TGC watershed encompassed about 80 percent of the perennial length of the channel of about $20 \mathrm{~km}$.

In addition to the stream sites, discharge from a 3-m diameter outfall that drains the area around the Aurora Municipal Complex and Aurora Mall and flows into WTGC near Chambers Road about $0.8 \mathrm{~km}$ upstream from the confluence with ETGC (OFS-1, fig. 1) was sampled to evaluate how much 
Selenium and Other Elements in Water and Adjacent Rock and Sediment of Toll Gate Creek, Colorado

Se load it contributed to TGC. A site in WTGC (WTGS-0.5) was included in the sample design to evaluate Se in WTGC directly upstream from OFS-1.

For each water-sampling event, all sampling sites of the stream drainage were sampled in a single day to minimize any day-to-day changes that might occur in the composition of the streamwater. Water sampling began at the most downstream locality then progressed upstream to avoid downstream disturbance of the stream.

\section{Discharge Measurement}

Discharge measurements were made by City of Aurora personnel at each site immediately following water sampling. The stream was divided into at least 3 and, if stream width permitted, as many as 10 measurement cells perpendicular to flow. For each cell, the width, average depth, and cross-sectional area were recorded. In each cell, stream velocity was measured at 0.6 times total depth using a Marsh McBirney Model 201 flowmeter. Discharge for each sampling site was calculated as the product of the cross-sectional area and the average flow velocity for the entire cross section. At some locations, the channel was too shallow to use the flowmeter. For example, at the outfall site (OFS-1) flow typically was about 30-centimeters $(\mathrm{cm})$ wide and only 1 - to 3 -cm deep. In this case, flow velocity was measured by pouring colored dye into the water, timing its transit along a measured distance, and multiplying flow by the measured cross-sectional area of the channel. There was a problem with the discharge measurement made at ETGS-1 during the December 16, 2003 sampling event. Therefore, discharge measurements were made at all sites on January 15, 2004. Because there were only minor differences in discharge at the other sites between the two dates, we assumed that the January 15, 2004 discharge measurement at ETGS-1 was representative of conditions during the December 16, 2003 sampling event and assigned the January discharge measurement to the site for the December sampling event. This is a reasonable assumption given that December and January are considered periods of baseflow in TGC and that paired December-January discharge measurements at other sites in the watershed showed very little difference. In addition, flow at the nearest USGS streamgaging station, Sand Creek at the Mouth near Commerce City, Colorado, showed similar flow for both days $13 \mathrm{ft}^{3} / \mathrm{s}$ (368 L/s) on December 16, 2003 and $15 \mathrm{ft}^{3} / \mathrm{s}(425 \mathrm{~L} / \mathrm{s})$ on January 1, 2004 http://waterdata.usgs.gov/co/nwis/dv/?site no394839104570300, accessed, July 2006) indicating that flow conditions were similar on the 2 days.

\section{Sampling and Processing}

Streamwater was sampled directly into 60 milliliter $(\mathrm{mL})$ plastic syringes. At each site, a new syringe and sample container were triple rinsed with streamwater to be sampled then shaken dry. The syringe was held facing upstream and moved across the width of the stream while sampling water. Using visual estimates of streamflow to guide sampling, sample volumes were obtained that were approximately proportional to flow.

Samples were filtered through new, 0.45 micrometer $(\mu \mathrm{m})$ pore-size, cellulose nitrate, surfactant-free, filters attached directly to the sampling syringe. The filters were prerinsed with $10 \mathrm{~mL}$ of the sample solution. Filtered samples were immediately measured for specific conductance, total dissolved solids (TDS), oxidation-reduction potential (ORP), and $\mathrm{pH}$ using a Myron L Ultrameter with automatic temperature compensation. The meter was calibrated onsite several times each day using commercially prepared conductivity and $\mathrm{pH}$ standards. For each day's sampling, a field procedural blank was collected using the standard field procedures and 18 meg-ohm (M $\Omega$ ) deionized water (DIW).

Filtered samples for trace-element analysis were acidified immediately upon collection in the field using three drops Ultrex nitric acid $\left(\mathrm{HNO}_{3}\right)$ per $20 \mathrm{~mL}$ of sample, which produced a pH value between 1 and 2 . The samples were stored at room temperature until analysis within 1 to 2 days after collection.

Two samples of raw (unfiltered) streamwater collected in December 2003 were analyzed using a modified USGS digestion procedure (Garbarino and Hoffman, 1999) to determine trace-element concentrations associated with suspended solids. Whole-water samples for this digestion procedure were collected (without any filtration or acid preservation) and refrigerated in the field and then frozen upon return to the laboratory until digestion. The digestion involved adding $1 \mathrm{~mL}$ of concentrated $\mathrm{HNO}_{3}$ to $30 \mathrm{~mL}$ of sample, heating to 60 degrees Celsius for 8 hours, cooling, and then filtering through a $0.45-\mu \mathrm{m}$ filter. Filtered solutions were diluted tenfold with 1-percent $\mathrm{HNO}_{3}$ solution before analysis.

\section{Analytical Methods for Water Samples}

Acidified-water samples and whole-water digestions were analyzed for major- and trace-element concentrations using Inductively Coupled Plasma-Mass Spectrometry (ICP-MS) because the technique has a detection sensitivity for Se of about $1 \mu \mathrm{g} / \mathrm{L}$ and also because the technique measures 36 other trace elements (table A1), including iron (Fe) and phosphorous $(\mathrm{P})$ which are sometimes associated with water-quality degradation. Other trace-elements measured include lithium $(\mathrm{Li})$, beryllium $(\mathrm{Be})$, aluminum $(\mathrm{Al})$, silicon $(\mathrm{Si})$, scandium $(\mathrm{Sc})$, titanium $(\mathrm{Ti})$, vanadium $(\mathrm{V})$, chromium $(\mathrm{Cr})$, manganese $(\mathrm{Mn})$, cobalt $(\mathrm{Co})$, nickel $(\mathrm{Ni})$, copper $(\mathrm{Cu})$, zinc $(\mathrm{Zn})$, gallium $(\mathrm{Ga})$, germanium $(\mathrm{Ge})$, arsenic (As), rubidium $(\mathrm{Rb})$, strontium $(\mathrm{Sr})$, yttrium $(\mathrm{Y})$, zirconium $(\mathrm{Zr})$, niobium $(\mathrm{Nb})$, molybdenum (Mo), cadmium $(\mathrm{Cd})$, antimony $(\mathrm{Sb})$, cesium $(\mathrm{Cs})$, barium $(\mathrm{Ba})$, lanthanum $(\mathrm{La})$, cerium $(\mathrm{Ce})$, tungsten $(\mathrm{W})$, thallium $(\mathrm{Tl})$, lead $(\mathrm{Pb})$, bismuth $(\mathrm{Bi})$, thorium $(\mathrm{Th})$, and uranium (U). This technique also includes the major ions sodium $(\mathrm{Na})$, magnesium $(\mathrm{Mg})$, potassium $(\mathrm{K})$, sulfur $(\mathrm{S})$ 
(which can be expressed as its common anion for the environmental conditions in TGC as sulfate $\left(\mathrm{SO}_{4}\right)$ ), and calcium $(\mathrm{Ca})$. In addition alkalinity, expected to be present as bicarbonate in these solutions with their near-neutral $\mathrm{pH}$, was measured on a few filtered samples using a sulfuric acid titration to an end-point $\mathrm{pH}$ of 4.5 (LaMotte Alkalinity Kit DR-A).

Analysis by ICP-MS was completed in the USGS Geology Discipline laboratories located in Denver, Colorado, using a A Perkin-Elmer Elan 6000 equipped with a conventional pneumatic nebulization sample-introduction system (Lamothe and others, 2002; Taggart 2002). Because concentrations of major ions in most samples were beyond the linear calibration range of the instrument, all samples were diluted tenfold with 1 percent $\mathrm{HNO}_{3}$ to obtain solutions within the calibrated concentration range. Even with this dilution, a few samples had $\mathrm{Na}$ concentrations that exceeded the calibrated concentration range, and these samples were reanalyzed after an additional tenfold dilution. All element concentrations for the water samples presented in table A1 represent the undiluted concentrations of the elements in the environmental samples.

The ICP-MS instrument was calibrated using three commercial multielement aqueous standards, plus two aqueous standards prepared inhouse, and one standard reference sample (T-143) available through the USGS Water Resources Discipline. Quality-assurance/quality-control procedures included assessment of analytical bias and precision and contamination. Standard reference materials and certified standards were analyzed to assess analytical bias (the difference between measured values and certified or "true" values). A standard reference solution from National Institute of Standards and Technology (NIST) (NIST-1643d) was analyzed at the beginning and end of each analytical run to assess bias for the analysis of samples collected in December 2003 and in March 2004. In addition, two standard reference water samples, T-161 and T-147, were analyzed to help assess bias during analysis of the March 2004 environmental samples. To assess precision (the spread in reported data values), three environmental sample replicates were analyzed during the analysis of the December 2003 samples. Replicate analysis of NIST-1634d, T-147, and T-161 provided estimates of precision for the samples collected and analyzed in March 2004. NIST-1634d was analyzed to assess bias and precision of analysis of the whole-water digestions of the two raw-water samples. To assess and prevent contamination, all sample analytical runs included a DIW wash or blank, and the ICP-MS procedure included a 90-second wash using a 2-percent $\mathrm{HNO}_{3}$ solution between each sample analysis. In addition, one field blank was collected during each sampling day using DIW and the standard field sampling procedure to help assess contamination introduced during sample collection and processing. Approximately 20 percent of the solutions analyzed with December 2003 environmental samples and approximately 30 percent of the solutions analyzed with the March 2004 environmental samples were quality-assurance/ quality-control samples. Approximately 40 percent of the solutions analyzed with the whole-water digestion samples were quality-assurance/quality-control samples. Analytical data for quality assurance and quality control for water samples collected during December 2003 and March 2004 are listed in table A2, in Appendix A at the back of the report, and the results are described in

Appendix B.

\section{Calculation of Load}

Se loads are the product of discharge and selenium concentration. The term instantaneous load is used because the loads were calculated using discharge measurements that represented one point in time. Instantaneous loads were reported as grams per day (g/d) and pounds per year (lbs/yr; table A1) because those terms are easier to conceptualize than micrograms per second. These calculations required converting the units of load (micrograms per second) by appropriate conversion factors to obtain grams per day and pounds per year. In some parts of the following discussion, the term "daily load" is used. This term refers the amount of selenium transported during 1 day as represented by the instantaneous load. For example, a Se load of $250 \mathrm{~g} / \mathrm{d}$ represents a daily Se load of $250 \mathrm{~g}$.

\section{Solid Sampling and Analytical Methods}

Twenty-one solid samples were collected and analyzed to determine the total amount of Se and other trace and major elements present in the bulk sample. A subset of these samples was treated using a deionized water-leaching procedure to assess the water-soluble concentrations of Se and other trace and major elements. X-ray diffraction analysis (XRD) was used to determine mineralogy of one sample.

\section{Solid Sampling Strategy and Locations}

Twenty-one solid samples comprised of rock (2 samples), a mixture of rock and unconsolidated sediment (13 samples), stream-sediment (3 samples), and efflorescence (surface encrustations produced by evaporation, 3 samples) were collected during January and February 2004. The results of the water analysis were used to develop a strategy to sample rocks and unconsolidated sediment that might contribute Se and other trace elements to the TGC. The December 2003 watersampling results indicated elevated $\mathrm{Se}$ in the waters throughout most of TGC and that Se loads increase in a downstream direction. Therefore, rocks and surficial material in proximity to TGC were sampled at several sites over most of the length of TGC (fig. 1). Sampling sites were numbered to correspond to water-sampling sites or were interpolated for locations between water-sampling sites, and A, B, C suffixes indicate 
different types of samples collected at the same locations (table 2, samples: TGS/R-; ETGS/R-; and WTGS/R-). No solid samples were obtained from the drainage of Sand Creek. Sample locations and descriptions are provided in table 2. Samples of the cuttings obtained during previous drilling and installation of two monitoring wells are listed as Ur-LUS samples in table 2.

Outcrops of natural rock and unconsolidated sediments are sparse along TGC. Much of the stream channel consists of added fill and slopes that have been graded for flood control (fig. 2). Most bedrock exposures in the drainage are several

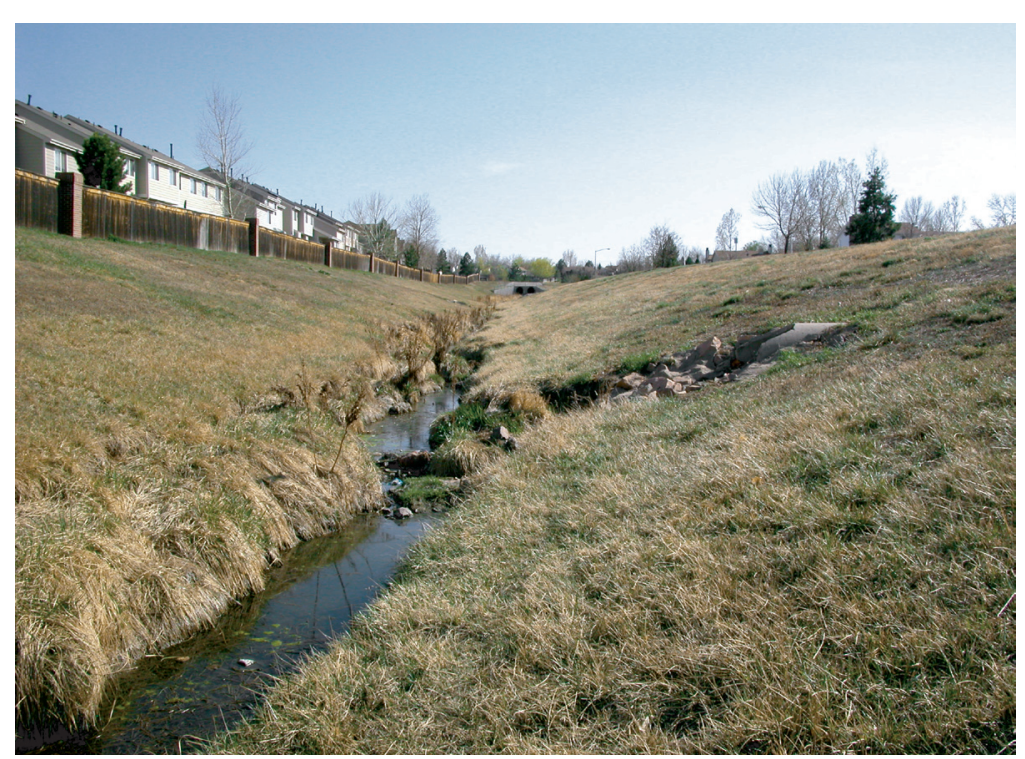

Figure 2. View of typical graded slope along bank of Toll Gate Creek. of TGC has distinct rocks of the Denver Formation exposed in the streambank and bottom (samples TGS/R-1.3 and -2.1A, B).

Some sample locations were selected based on field observations. One sample was collected from anoxic mud in the stream bottom of WTGC (WTGS/R-2.2B) to represent sediments from the wetlands that occur in some locations along WTGC and ETGC. A sample of silty-stream sediment was taken at Station 3.5 of WTGC (WTGS/R-3.5B). Another stream sediment consisting of iron-rich sand was collected about midway down the course of WTGC (WTGS/R-1.4C).

The portable EDXRF analyzer (see Analytical Methods for Solid Samples section) indicated this iron-rich sample had an approximate composition of 89 percent Fe and 3 percent Mn. This sample was included because Fe and Se occasionally are associated in some sedimentary rock systems (Grauch et al., 2004). Last, three samples were taken of a white efflorescence that occurred on rock surfaces above water level along the stream channel (WTGS/R-1.4B, -2.2A, and -3.5A). This encrustation apparently results from evaporative concentration of dissolved solids in ground water and(or) the capillary fringe of the stream.

Based on work in a seleniferous shale sequence, (Herring, 2004; Herring and Grauch, 2004), the Se content in exposed, weathered surficial rocks is typically much less than in deeper underlying equivalents of those rocks, because the Se in the exposed rock weathers into highly soluble oxidized species and is removed by ground-water leaching. Consequently, part of the sample design included obtaining some deeper, unexposed samples of the same rock units as the

hundred meters away from the stream. Because the interest was in sampling only those rocks in direct or most proximal contact with the streamwater, bedrock sections away from the stream were not sampled. Where exposed, the rock and unconsolidated sediments generally were light tan and appeared well weathered. Rock and unconsolidated sediment samples were taken at locations where there was a relatively uniform presence in color and apparent composition through the streambank deposits (fig. 3). These uniform rock sections were sampled along the vertical extent of exposure without regard to the unconsolidated sediment or rock type to obtain a single, composite sample that was representative of the rock sequence at that site. The sample was collected by compositing a continuous set of rock chips along a straight line, perpendicular to bedding planes in the outcrop. This type of composite sample is termed a channel sample. The contact between the unconsolidated sediments and underlying bedrock can be transitional and often was difficult to identify. Only the lowermost reach

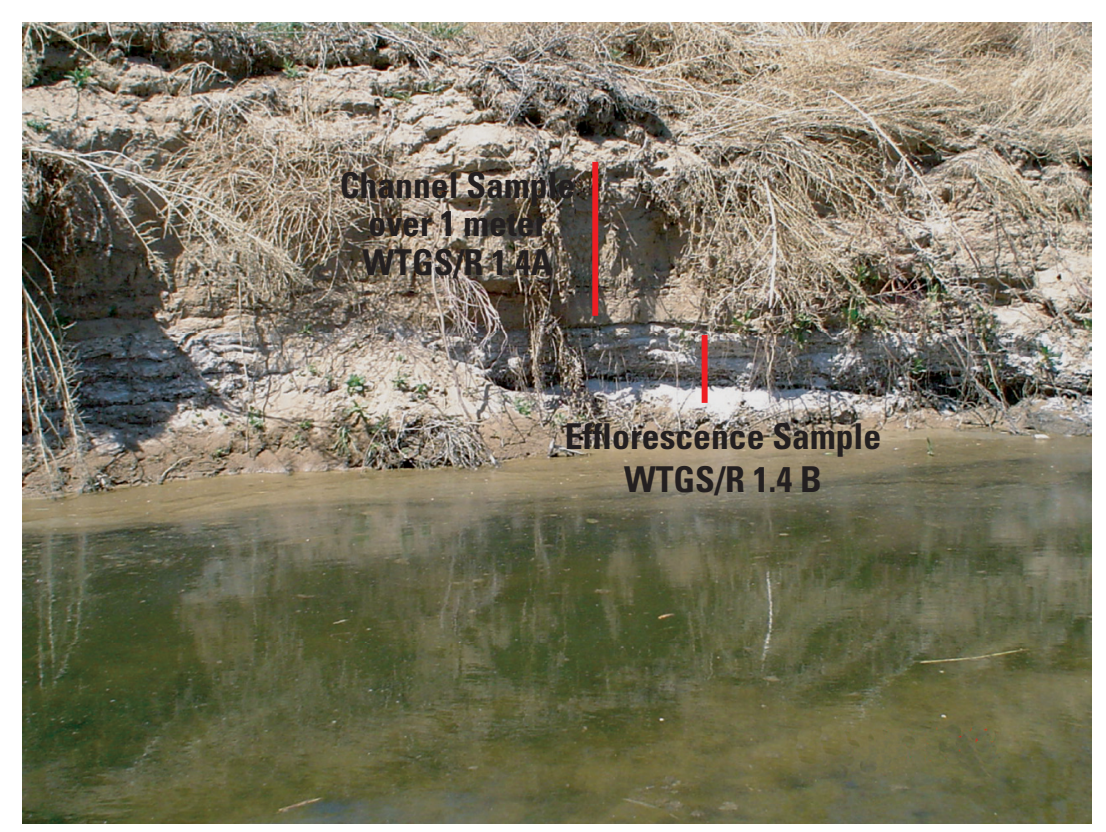

Figure 3. View of streambank channel sample WTGS/R-1.4A directly north of the Mississippi Street overpass. Note efflorescence zone, sampled as WTGS/R-1.4B. 
Table 2. Location and description of solid sampling locations, Toll Gate Creek.

[m, meter; km, kilometer; USGS, U.S. Geological Survey; NAWQA, National Water-Quality Assessment; UrLUS, urban land use study; Rk. Btm, bedrock from stream bottom; Ch. Sed., channel sample of streambank sediments; Latitude and longitude referenced to North American Datum 1983; Fe, iron]

\begin{tabular}{|c|c|c|c|c|c|}
\hline $\begin{array}{l}\text { USGS } \\
\text { lab no. }\end{array}$ & Sample & $\begin{array}{l}\text { Latitude } \\
\text { (decimal } \\
\text { degrees) }\end{array}$ & $\begin{array}{l}\text { Longitude } \\
\text { (decimal } \\
\text { degrees) }\end{array}$ & $\begin{array}{l}\text { Depth } \\
(\mathrm{m})\end{array}$ & Comments \\
\hline \multicolumn{6}{|c|}{ Toll Gate Creek } \\
\hline $\mathrm{C}-230083$ & TGS/R-1.3 & 39.74517 & -104.82692 & Surface & $\begin{array}{l}\text { Composite along } 30 \mathrm{~m} \text { of streambank of stream-channel material consisting of in-place bedrock } \\
\text { and channel deposits }\end{array}$ \\
\hline C-230081 & TGS/R-2 & 39.73008 & -104.82043 & Surface & $\begin{array}{l}\text { Channel sample of } 3-\mathrm{m} \text { high streambank above water of running stream, } 30 \mathrm{~m} \text { upstream from } \\
\text { footbridge and approximately } 0.4 \mathrm{~km} \text { downstream from water-sample site TGS- } 2\end{array}$ \\
\hline C-230087 & TGS/R-2.1 A & 39.72463 & -104.81670 & Surface & Sandstone bedrock bottom in stream \\
\hline C-230088 & TGS/R-2.1 B & 39.72463 & -104.81670 & Surface & $\begin{array}{l}\text { Composite channel sample of streambank deposits through } 2 \mathrm{~m} \text { of vertical height on east side of } \\
\text { streambank approximately } 100 \mathrm{~m} \text { upstream from Urban Drainage and Flood Control District } \\
\text { stream-gaging station }\end{array}$ \\
\hline \multicolumn{6}{|r|}{ East Toll Gate Creek } \\
\hline $\mathrm{C}-230077$ & ETGS/R-1 & 39.71751 & -104.80638 & Surface & $\begin{array}{l}\text { Channel sample of 3-m high streambank on east side of stream above running water at location } \\
\text { of ETGS-1 water-sampling site }\end{array}$ \\
\hline C-230075 & ETGS/R-2 & 39.70082 & -104.77437 & Surface & $\begin{array}{l}\text { Equal mix of: channel sample of bank above water of running stream; and channel sample of } \\
\text { bank in dry reach of stream }\end{array}$ \\
\hline \multicolumn{6}{|r|}{ West Toll Gate Creek } \\
\hline $\mathrm{C}-230086$ & WTGS/R-1.1 & 39.71202 & -104.80660 & Surface & $\begin{array}{l}\text { Composite channel sample of streambank deposits through } 4 \mathrm{~m} \text { of vertical height on north side } \\
\text { of streambank just after sharp bend in stream to west }\end{array}$ \\
\hline C-230090 & WTGS/R-1.4A & 39.69693 & -104.80483 & Surface & $\begin{array}{l}\text { Streambank sediment channel sampled along } 2.5-\mathrm{m} \text { vertical section above flowing water; } \\
\text { alternations of silt, gravel, and sand layers }\end{array}$ \\
\hline C-230084 & WTGS/R-1.4B & 39.69693 & -104.80483 & Surface & White efflorescence in streambank deposits directly above flowing water \\
\hline C-230085 & WTGS/R-1.4C & 39.69693 & -104.80483 & Surface & Fe-rich sand in stream channel \\
\hline C-230089 & WTGS/R-1.7 & 39.68753 & -104.80460 & Surface & $\begin{array}{l}\text { Composite channel sample through } 8 \mathrm{~m} \text { of vertical height along bulldozer scrape on west side } \\
\text { of streambank }\end{array}$ \\
\hline C-230079 & WTGS/R-2.2A & 39.67660 & -104.79087 & Surface & Efflorescence on streambank \\
\hline C-230082 & WTGS/R-2.2B & 39.67660 & -104.79087 & Surface & Anoxic mud in flowing stream bottom \\
\hline C-230080 & WTGS/R-3.5A & 39.62608 & -104.75158 & Surface & Efflorescence on streambank \\
\hline C-230076 & WTGS/R-3.5B & 39.62608 & -104.75158 & Surface & Stream sediment \\
\hline C-230078 & WTGS/R-3.5C & 39.62608 & -104.75158 & Surface & Mud/rock bank along stream \\
\hline \multicolumn{6}{|c|}{ USGS NAWQA well auger cuttings } \\
\hline C-230070 & UrLUS18-1 & 39.64631 & -104.78228 & $5.79-6.10$ & \\
\hline C-230073 & UrLUS18-2 & 39.64631 & -104.78228 & $8.69-8.99$ & Contains gypsum crystals \\
\hline C-230072 & UrLUS19-1 & 39.64006 & -104.76611 & $3.35-3.66$ & \\
\hline C-230071 & UrLUS19-2 & 39.64006 & -104.76611 & $6.40-6.71$ & \\
\hline C-230074 & UrLUS19-3 & 39.64006 & -104.76611 & $12.80-13.11$ & \\
\hline
\end{tabular}


streambank deposits. Five rock and unconsolidated sediment samples were obtained from the base of two shallow USGS National Water-Quality Assessment Program (NAWQA) monitoring wells that were installed (using a hollow stem auger) in the watershed of TGC (see: http://co.water.usgs. gov/nawqa/splt/index.html). The borehole samples ranged in depth from 3 to $13 \mathrm{~m}$ below the ground surface.

\section{Analytical Methods for Solid Samples}

A mix of analytical techniques was used for solid samples. All solid samples collected were analyzed using EDXRF. Selected solid samples were treated using a deionized water or nitric-acid leaching procedure and then analyzed using ICP-MS. X-ray diffraction was used to identify minerals in selected samples.

Solids were analyzed using nondestructive, direct measurement of bulk chemical content using EDXRF. The technique, and its accuracy and precision, were described by Siems (2002). The laboratory technique provides detection sensitivity for Se at about 1 part per million (ppm) and also measures 29 other elements. The lower limit of detection (LLD) for each element is listed in table 3. Elements that were detected but for which all samples had concentrations either below the LLD or only a few values with a maximum concentration equal to twice the LLD were, with their LLD in parts per million in parentheses: Ge (2), Ag (1), Cd (1), Sb (2), W (5), and $\mathrm{Bi}$ (5). These elements were eliminated from the data set and subsequent evaluation.

Initially, a field-portable EDXRF unit was used to help select rock and unconsolidated sediment sampling for more detailed laboratory analysis. Unfortunately, its lower detection limit of about $30 \mathrm{ppm}$ Se was too high to detect Se in most of the rocks along the TGC drainage. However, the unit was used to help locate samples for other analytes of interest.

A deionized water-leaching procedure was used for the three efflorescence samples and the anoxic mud (samples WTGS/R-1.4B, WTGS/R-2.2A, WTGS/R-3.5A, and WTGS/ $\mathrm{R}-2.2 \mathrm{~B})$ and is similar to the method of Herring (2004).

Briefly, solid samples ground to $<100$ mesh $(<0.15$ millimeter $(\mathrm{mm})$ ) were reacted with DIW in a mass ratio of 20:1 water to solids without agitation for 30 minutes, centrifuged, and the decanted solution then was filtered at $0.45 \mu \mathrm{m}$, acidified, and injected directly into the ICP-MS. Two samples of stream sediment (WTGS/R-2.2B, anoxic mud; TGS/R-2.1A bedrock from the stream bottom) were digested using nitric acid and heat to compare the amount of Se that could be liberated using this procedure with the amount detected by EDXRF in the bulk-sediment sample. This digestion technique is similar to that used for the raw water, described above (see Analytical Methods for Water Samples section), except that 1 gram (g) of ground sediment was added to $30 \mathrm{~mL}$ of deionized water, acidified, heated, and cooled. The resulting solution was filtered, diluted tenfold with 1-percent $\mathrm{HNO}_{3}$, and injected directly into the ICP-MS.
XRD patterns were collected $(\mathrm{Cu} \mathrm{K}$-alpha radiation, Peltier counter) on a Scintag X-1 theta-theta diffractometer with 2-mm divergence slit and 4-mm scatter slit for the tube and $0.5-\mathrm{mm}$ scatter slit and $0.2-\mathrm{mm}$ receiving slit for the detector. Patterns were scanned from 4 to 70 degrees 2-theta at a power setting of 45 kilovolts $(\mathrm{kV})$ and 35 milliamperes $(\mathrm{mA})$ with a step size of 0.02 degree 2-theta and a counting time of 2 seconds per step with a sample spinner to reduce preferred orientation (Steve Sutley, U.S. Geological Survey, written commun., July 2006).

\section{Selenium and Other Trace Elements in Water}

Results from discharge measurements and chemical analysis of samples were used to assess Se occurrence in the water of the TGC watershed. Load profiles of Se within the TGC watershed were used to evaluate the location and distribution of Se input to TGC.

\section{Discharge}

Discharge ranged from 2.5 L/s at ETGS-2 in December 2003 to 138 L/s at TGS-1 in March 2004 (fig. 4). Discharge increased in a downstream direction in WTGC, ETGC, and downstream from the confluence of ETGC and WTGC to TGS-1 during both sampling events. Discharge decreased in a downstream direction along ETGC during both sampling events. Upstream from ETGS-2, the stream channel was dry. These data indicate that TGC is a gaining stream along

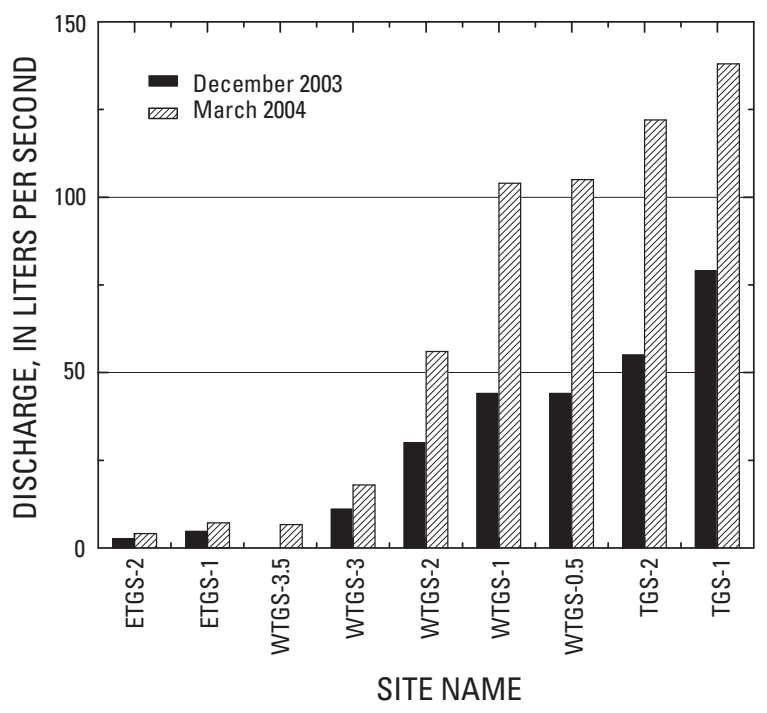

Figure 4. Discharge profile along Toll Gate Creek for December 2003 and March 2004 sampling events. Results from Sand Creek and outfall sampling locations not included on this graph. 
Table 3. Energy Dispersive X-Ray Fluorescence (EDXRF) analysis of rock and unconsolidated sediment samples adjacent to Toll Gate Creek.

[ppm, parts per million; USGS, U.S. Geological Survey; NAWQA, National Water-Quality Assessment; Se, selenium; Sr, strontium; Y, yttrium; Zr, zirconium; Nb, niobium; Ba, barium; $\mathrm{Ni}$, nickel; Cu, copper; Zn, zinc; V, vanadium; Cr, chromium; Ga, gallium; As, arsenic; Br, bromine; Mo, molybdenum; Sn, tin; Cs, cesium; La, lanthanum; Ce, cerium; Nd, neodymium; Pb, lead; Th, thorium; U, uranium; TGS/R, Toll Gate Creek solid sample; ETGS/R, East Toll Gate Creek solid sample; WTGS/R, West Toll Gate Creek solid sample; UrLUS, urban land use study; <, less than; A, B, or C suffix on sample indicates different sample types collected at same location, see table 2]

\begin{tabular}{|c|c|c|c|c|c|c|c|c|}
\hline $\begin{array}{l}\text { USGS } \\
\text { lab number }\end{array}$ & Sample & $\begin{array}{c}\mathrm{Se} \\
(\mathrm{ppm})\end{array}$ & $\underset{(p p m)}{\mathrm{Sr}}$ & $\begin{array}{c}Y \\
\text { (ppm) }\end{array}$ & $\begin{array}{c}\mathrm{Zr} \\
(\mathrm{ppm})\end{array}$ & $\begin{array}{c}\text { Nb } \\
(\mathrm{ppm})\end{array}$ & $\begin{array}{c}\mathrm{Ba} \\
(\mathrm{ppm})\end{array}$ & $\underset{(\mathrm{ppm})}{\mathrm{Ni}}$ \\
\hline \multicolumn{2}{|c|}{ Lower Limit of Detection } & 1 & 2 & 2 & 2 & 2 & 5 & 2 \\
\hline \multicolumn{9}{|l|}{ Toll Gate Creek } \\
\hline C-230083 & TGS/R-1.3 & 2 & 888 & 30 & 227 & 15 & 1,080 & 12 \\
\hline C-230081 & TGS/R-2 & $<1$ & 513 & 37 & 463 & 22 & 1,020 & 19 \\
\hline C-230087 & TGS/R-2.1A & 3 & 974 & 35 & 235 & 15 & 671 & 10 \\
\hline C-230088 & TGS/R-2.1B & $<1$ & 631 & 34 & 347 & 16 & 867 & 12 \\
\hline \multicolumn{9}{|c|}{ East Toll Gate Creek } \\
\hline $\mathrm{C}-230077$ & ETGS/R-1 & $<1$ & 393 & 43 & 526 & 20 & 1,010 & 18 \\
\hline C-230075 & ETGS/R-2 & 1 & 382 & 42 & 400 & 18 & 961 & 22 \\
\hline \multicolumn{9}{|c|}{ West Toll Gate Creek } \\
\hline C-230086 & WTGS/R-1.1 & $<1$ & 404 & 55 & 670 & 24 & 1,030 & 24 \\
\hline C-230090 & WTGS/R-1.4A & $<1$ & 500 & 63 & 951 & 34 & 1,100 & 23 \\
\hline C-230084 & WTGS/R-1.4B & 25 & 582 & 42 & 360 & 14 & 654 & 12 \\
\hline C-230085 & WTGS/R-1.4C & $<1$ & 202 & 168 & 1,470 & 57 & 324 & 25 \\
\hline C-230089 & WTGS/R-1.7 & $<1$ & 495 & 64 & 942 & 32 & 1,110 & 26 \\
\hline C-230079 & WTGS/R-2.2A & 3 & 830 & 30 & 200 & 11 & 696 & 13 \\
\hline C-230082 & WTGS/R-2.2B & 5 & 1,220 & 17 & 208 & 13 & 555 & 17 \\
\hline C-230080 & WTGS/R-3.5A & 4 & 464 & 12 & 104 & 8 & 391 & 9 \\
\hline C-230076 & WTGS/R-3.5B & 4 & 557 & 34 & 349 & 19 & 938 & 20 \\
\hline C-230078 & WTGS/R-3.5C & 2 & 786 & 31 & 289 & 20 & 1,290 & 24 \\
\hline \multicolumn{9}{|c|}{ USGS NAWQA well auger cuttings } \\
\hline $\mathrm{C}-230070$ & UrLUS18-1 & $<1$ & 265 & 17 & 143 & 9 & 1,070 & 8 \\
\hline $\mathrm{C}-230073$ & UrLUS18-2 & $<1$ & 469 & 33 & 332 & 18 & 1,130 & 18 \\
\hline $\mathrm{C}-230072$ & UrLUS19-1 & $<1$ & 316 & 30 & 275 & 23 & 504 & 25 \\
\hline C-230071 & UrLUS19-2 & $<1$ & 327 & 13 & 277 & 23 & 463 & 11 \\
\hline C-230074 & UrLUS19-3 & $<1$ & 402 & 35 & 262 & 24 & 654 & 18 \\
\hline
\end{tabular}


Table 3. Energy Dispersive X-Ray Fluorescence (EDXRF) analysis of rock and unconsolidated sediment samples adjacent to Toll Gate Creek.-Continued

[ppm, parts per million; USGS, U.S. Geological Survey; NAWQA, National Water-Quality Assessment; Se, selenium; Sr, strontium; Y, yttrium; Zr, zirconium; $\mathrm{Nb}$, niobium; Ba, barium; Ni, nickel; Cu, copper; Zn, zinc; V, vanadium; Cr, chromium; Ga, gallium; As, arsenic; Br, bromine; Mo, molybdenum; Sn, tin; Cs, cesium; La, lanthanum; Ce, cerium; Nd, neodymium; Pb, lead; Th, thorium; U, uranium; TGS/R, Toll Gate Creek solid sample; ETGS/R, East Toll Gate Creek solid sample; WTGS/R, West Toll Gate Creek solid sample; UrLUS, urban land use study; <, less than; A, B, or C suffix on sample indicates different sample types collected at same location, see table 2]

\begin{tabular}{|c|c|c|c|c|c|c|c|c|c|c|}
\hline $\begin{array}{l}\text { USGS } \\
\text { lab number }\end{array}$ & Sample & $\underset{(p p m)}{C u}$ & $\begin{array}{c}\mathrm{Zn} \\
(\mathrm{ppm})\end{array}$ & $\begin{array}{c}V \\
(p p m)\end{array}$ & $\underset{(p p m)}{C r}$ & $\begin{array}{c}\text { Ga } \\
(\mathrm{ppm})\end{array}$ & $\begin{array}{c}\text { As } \\
\text { (ppm) }\end{array}$ & $\begin{array}{c}\mathrm{Br} \\
(\mathrm{ppm})\end{array}$ & $\begin{array}{c}\text { Mo } \\
\text { (ppm) }\end{array}$ & $\begin{array}{c}\text { Sn } \\
(\mathrm{ppm})\end{array}$ \\
\hline \multicolumn{2}{|c|}{ Lower Limit of Detection } & 2 & 2 & 5 & 5 & 2 & 2 & 1 & 2 & 2 \\
\hline \multicolumn{11}{|l|}{ Toll Gate Creek } \\
\hline $\mathrm{C}-230083$ & TGS/R-1.3 & 37 & 97 & 108 & 28 & 20 & 10 & 4 & 10 & 2 \\
\hline C-230081 & TGS/R-2 & 24 & 97 & 123 & 35 & 16 & 3 & 8 & $<2$ & 2 \\
\hline C-230087 & TGS/R-2.1A & 23 & 124 & 96 & 16 & 23 & 2 & 6 & 2 & 3 \\
\hline C-230088 & TGS/R-2.1B & 27 & 95 & 110 & 35 & 17 & 3 & 13 & $<2$ & $<2$ \\
\hline \multicolumn{11}{|c|}{$\begin{array}{l}\text { East Toll Gate Creek } \\
\text {. }\end{array}$} \\
\hline C-230077 & ETGS/R-1 & 32 & 87 & 117 & 42 & 17 & 6 & 5 & $<2$ & 3 \\
\hline C-230075 & ETGS/R-2 & 27 & 88 & 90 & 41 & 17 & 4 & 12 & 3 & 3 \\
\hline \multicolumn{11}{|c|}{ West Toll Gate Creek } \\
\hline C-230086 & WTGS/R-1.1 & 28 & 112 & 229 & 46 & 18 & 5 & 2 & $<2$ & 4 \\
\hline C-230090 & WTGS/R-1.4A & 36 & 141 & 168 & 50 & 19 & 5 & 6 & $<2$ & 4 \\
\hline C-230084 & WTGS/R-1.4B & 19 & 79 & 90 & 28 & 10 & 3 & 91 & $<2$ & $<2$ \\
\hline C-230085 & WTGS/R-1.4C & 79 & 469 & 669 & 545 & 35 & 8 & 2 & $<2$ & 8 \\
\hline C-230089 & WTGS/R-1.7 & 32 & 135 & 167 & 45 & 19 & 4 & 5 & $<2$ & 3 \\
\hline C-230079 & WTGS/R-2.2A & 23 & 95 & 58 & 25 & 11 & 3 & 38 & $<2$ & 3 \\
\hline C-230082 & WTGS/R-2.2B & 84 & 104 & 88 & 32 & 12 & 2 & 14 & 2 & $<2$ \\
\hline C-230080 & WTGS/R-3.5A & 15 & 46 & 32 & 18 & 8 & 2 & 80 & $<2$ & 2 \\
\hline C-230076 & WTGS/R-3.5B & 30 & 118 & 103 & 50 & 19 & 7 & 17 & 2 & 4 \\
\hline C-230078 & WTGS/R-3.5C & 29 & 93 & 103 & 39 & 17 & 4 & 19 & 2 & 3 \\
\hline \multicolumn{11}{|c|}{$\begin{array}{l}\text { USGS NAWQA well auger cuttings } \\
\end{array}$} \\
\hline $\mathrm{C}-230070$ & UrLUS18-1 & 11 & 35 & 47 & 26 & 12 & $<2$ & 4 & $<2$ & $<2$ \\
\hline C-230073 & UrLUS18-2 & 24 & 75 & 104 & 35 & 18 & 4 & 3 & $<2$ & 2 \\
\hline C-230072 & UrLUS19-1 & 53 & 118 & 117 & 43 & 26 & 9 & 10 & 4 & 3 \\
\hline C-230071 & UrLUS19-2 & 22 & 87 & 118 & 26 & 27 & $<2$ & 1 & $<2$ & $<2$ \\
\hline C-230074 & UrLUS19-3 & 54 & 117 & 148 & 36 & 26 & $<2$ & 1 & 2 & $<2$ \\
\hline
\end{tabular}


Table 3. Energy Dispersive X-Ray Fluorescence (EDXRF) analysis of rock and unconsolidated sediment samples adjacent to Toll Gate Creek.-Continued

[ppm, parts per million; USGS, U.S. Geological Survey; NAWQA, National Water-Quality Assessment; Se, selenium; Sr, strontium; Y, yttrium; Zr, zirconium; Nb, niobium; Ba, barium; Ni, nickel; Cu, copper; Zn, zinc; V, vanadium; Cr, chromium; Ga, gallium; As, arsenic; $\mathrm{Br}$, bromine; Mo, molybdenum; Sn, tin; Cs, cesium; La, lanthanum; Ce, cerium; Nd, neodymium; Pb, lead; Th, thorium; U, uranium; TGS/R, Toll Gate Creek solid sample; ETGS/R, East Toll Gate Creek solid sample; WTGS/R, West Toll Gate Creek solid sample; UrLUS, urban land use study; <, less than; A, B, or C suffix on sample indicates different sample types collected at same location, see table 2]

\begin{tabular}{|c|c|c|c|c|c|c|c|c|}
\hline $\begin{array}{l}\text { USGS } \\
\text { lab } \\
\text { number }\end{array}$ & Sample & $\begin{array}{c}\text { Cs } \\
(\mathrm{ppm})\end{array}$ & $\begin{array}{c}\text { La } \\
\text { (ppm) }\end{array}$ & $\begin{array}{c}\text { Ce } \\
\text { (ppm) }\end{array}$ & $\begin{array}{c}\text { Nd } \\
(\mathrm{ppm})\end{array}$ & $\begin{array}{c}\mathrm{Pb} \\
(\mathrm{ppm})\end{array}$ & $\begin{array}{c}\text { Th } \\
\text { (ppm) }\end{array}$ & $\begin{array}{c}\mathbf{U} \\
(\mathrm{ppm})\end{array}$ \\
\hline Lower Limit of & Detection & 5 & 5 & 5 & 10 & 3 & 4 & 4 \\
\hline \multicolumn{9}{|l|}{ Toll Gate Creek } \\
\hline C-230083 & TGS/R-1.3 & $<5$ & 52 & 94 & 44 & 23 & 11 & $<4$ \\
\hline C-230081 & TGS/R-2 & 6 & 52 & 103 & 51 & 26 & 9 & 5 \\
\hline C-230087 & TGS/R-2.1A & $<5$ & 41 & 88 & 44 & 21 & 4 & $<4$ \\
\hline $\mathrm{C}-230088$ & TGS/R-2.1B & $<5$ & 49 & 100 & 47 & 26 & 9 & 4 \\
\hline \multicolumn{9}{|c|}{ East Toll Gate Creek } \\
\hline C-230077 & ETGS/R-1 & 6 & 82 & 161 & 77 & 30 & 21 & 5 \\
\hline $\mathrm{C}-230075$ & ETGS/R-2 & 10 & 63 & 118 & 58 & 28 & 18 & 4 \\
\hline \multicolumn{9}{|c|}{ West Toll Gate Creek } \\
\hline C-230086 & WTGS/R-1.1 & $<5$ & 93 & 189 & 77 & 24 & 21 & 7 \\
\hline C-230090 & WTGS/R-1.4A & 6 & 77 & 160 & 82 & 33 & 22 & 7 \\
\hline C-230084 & WTGS/R-1.4B & $<5$ & 49 & 101 & 44 & 20 & 12 & 8 \\
\hline C-230085 & WTGS/R-1.4C & $<5$ & 219 & 473 & 215 & 83 & 107 & 16 \\
\hline C-230089 & WTGS/R-1.7 & $<5$ & 73 & 152 & 70 & 35 & 15 & 6 \\
\hline C-230079 & WTGS/R-2.2A & 6 & 35 & 67 & 31 & 20 & 8 & 5 \\
\hline C-230082 & WTGS/R-2.2B & $<5$ & 25 & 53 & 21 & 18 & 8 & 7 \\
\hline C-230080 & WTGS/R-3.5A & $<5$ & 23 & 40 & 17 & 11 & 5 & 21 \\
\hline C-230076 & WTGS/R-3.5B & 8 & 49 & 94 & 46 & 27 & 14 & 5 \\
\hline C-230078 & WTGS/R-3.5C & 11 & 56 & 101 & 46 & 23 & 9 & 5 \\
\hline \multicolumn{9}{|c|}{ USGS NAWQA well auger cuttings } \\
\hline C-230070 & UrLUS18-1 & 11 & 33 & 51 & 36 & 24 & $<4$ & $<4$ \\
\hline C-230073 & UrLUS18-2 & 11 & 58 & 111 & 54 & 23 & 10 & $<4$ \\
\hline C-230072 & UrLUS19-1 & 7 & 56 & 110 & 55 & 26 & 15 & 4 \\
\hline C-230071 & UrLUS19-2 & $<5$ & 20 & 33 & 16 & 20 & 11 & $<4$ \\
\hline C-230074 & UrLUS19-3 & 6 & 54 & 101 & 53 & 22 & 10 & $<4$ \\
\hline
\end{tabular}


the reaches sampled for this study. The increase in streamflow along most of the stream length likely results from ground-water discharge to the stream. The greatest increases in discharge occurred between TGS-2 and TGS-1 during the December sampling event, and between WTGS-2 and WTGS-1 during the March sampling event. The discharge at TGS-1 was greater than the flow in Sand Creek upstream from the confluence with TGC by at least a factor of 4 during both sampling events (table A1). Discharge was greater during March 2004 than in December 2003. The greater flow during March 2004 may be due to snowmelt or spring rain or increased ground-water discharge to the stream resulting from infiltration of recent snowmelt and spring rain. Streamflow in December represents base-flow conditions. The slightly higher flow in March was likely caused by infiltration and release of snowmelt or spring rain. At the USGS streamgage at Sand Creek at the mouth, daily mean discharge was 11 and $12 \mathrm{ft}^{3} / \mathrm{s}$ (311 and 340 L/s) December 16 and 17, 2003 and approximately $20 \mathrm{ft}^{3} / \mathrm{s}$ (566 L/s) on March 2, 2004, although during March this flow may have been elevated from discharge from a ditch or Aurora Sand Creek Waste Water Reclamation plant that discharge to Sand Creek between the confluence with TGC and the mouth of Sand Creek

(http://waterdata.usgs.gov/co/nwis/dv/?site_ no394839104570300, accessed, July 2006). Thus, the December 2003 and March 2004 sampling events were conducted during low-flow conditions on TGC, and conclusions presented herein are valid only for those flow conditions.

\section{Element Concentrations in Water}

Concentrations of Se, other analytes, and Se loads from all water samples are listed in table A1, and Se concentrations are shown for most TGC sites in figure 5. Table A2 lists results of analysis of quality-assurance samples. Details of qualityassurance and quality-control procedures and calculations are reported in Appendix B. The results indicated that precision and bias of all analyses were generally within acceptable limits (about 10 percent for bias and about 5 percent for precision). There was a possible high bias for Fe analyses. There was no contamination in the procedural blank samples except for Zn; blank samples collected during December 2003 had $\mathrm{Zn}$ concentrations similar to those measured in environmental samples. It is possible that $\mathrm{Zn}$ was present in the DIW used to prepare the blank samples. However, analysis of the $\mathrm{Zn}$ data is not critical to conclusions presented herein, so the contamination is inconsequential with regard to this study.

Se concentrations ranged from 7 to $70 \mu \mathrm{g} / \mathrm{L}$ and had an average value of about $23 \mu \mathrm{g} / \mathrm{L}$ for all TGC watershed streamwater samples (excluding the water samples from the outfall, OFS-1). These values are greater than the State stream standard of $4.6 \mu \mathrm{g} / \mathrm{L}$. The average for the December 2003 stream samples, $28 \mu \mathrm{g} / \mathrm{L}$, exceeded that for the March 2004 stream samples, $14 \mu \mathrm{g} / \mathrm{L}$. In addition, the Se concentrations during December 2003 had a greater range in concentrations, whereas the March 2004 samples had a lower range in concentrations and a flatter concentration profile, particularly downstream from and including WTGS-2 (fig. 5).

The two samples with the greatest Se concentration, again excluding the outfall, came from the most upstream

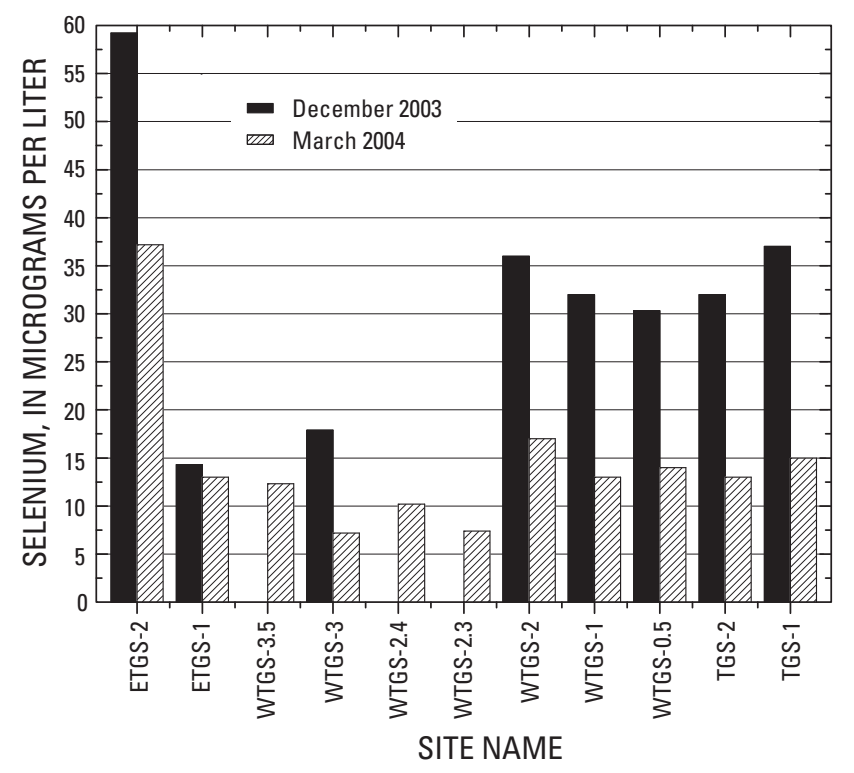

Figure 5. Selenium concentration profile along Toll Gate Creek for December 2003 and March 2004 sampling events. Results from Sand Creek and outfall sampling locations not included on this graph.

location on ETGC. In addition, in March, WTGS-3.5 had elevated Se concentrations. These data from the upstreammost sites in the basin combined with elevated Se concentrations all the way downstream to the mouth of TGC indicate that elevated Se concentrations are widespread throughout the TGC watershed and that elevated Se concentrations exist well upstream (WTGS-3.5 and ETGS-2) from any industrial sources.

The greatest increase in Se concentration occurred between WTGS-3 and WTGS-2 during the December sampling (fig. 5). This large increase may indicate a source between the two locations. However, more detailed sampling between WTGS-3 and WTGS-2 that occurred in March 2004, included sampling upstream and downstream from a pond (WTGS-2.4 and WTGS-2.3, table A1, fig. 5). These samples did not identify the pond or the tributary that flows into it from the east as the source of elevated Se concentration, but they indicate a possible source located between WTGS-2.3 and WTGS-2 (fig. 5).

Arsenic (As) in TGC often was below the detection limit. However, As concentrations ranged from 2 to $6 \mu \mathrm{g} / \mathrm{L}$ in stream samples taken in TGC on December 17, 2003.

During December 2003 the outfall (OFS-1) had the greatest Se concentrations measured during the study (133 and $131 \mu \mathrm{g} / \mathrm{L}$ ). In addition, the outfall (OFS-1) had concentrations of several elements that were greater than those in any 
of the streamwater samples (table A1). Se and sulfate had their highest measured concentrations of all water samples in the December 16, 2003 outfall sample. For Sb, the December sampling shows an average of $2.2 \mu \mathrm{g} / \mathrm{L}$ and the March sample was about $6.9 \mu \mathrm{g} / \mathrm{L}$ at the outfall. The lesser Sb concentrations downstream from the outfall on TGC appear to be dilutions of this larger concentration. Most streamwater samples upstream from the outfall were near to or below the detection limit of $0.3 \mu \mathrm{g} / \mathrm{L}$ for $\mathrm{Sb}$. For As, the December water samples at the outfall averaged about $5 \mu \mathrm{g} / \mathrm{L}$.

For the TGC water samples, anion composition can be approximated using the alkalinity and ICP-MS sulfate data. Alkalinity ranged from 230 to $340 \mathrm{mg} / \mathrm{L}$ as $\mathrm{CaCO}_{3}$ (table A1). The presence of substantive amounts of other anions can be tested by estimating a charge balance for the samples by summing the concentration (in equivalents per liter) of the measured anions (sulfate and alkalinity) and comparing this sum to the sum of the concentration (in equivalents per liter) of the major cations ( $\mathrm{Ca}, \mathrm{Mg}, \mathrm{K}$, and $\mathrm{Na}$ ) that were determined using the ICP-MS. Estimating an average alkalinity of $300 \mathrm{mg} / \mathrm{L} \mathrm{CaCO}_{3}$ for all samples, the calculated bicarbonate concentration, using a conversion factor of 1.22 , is $366 \mathrm{mg} / \mathrm{L}$. A calculated charge balance for all water samples (using $\mathrm{Na}, \mathrm{K}, \mathrm{Mg}$, and $\mathrm{Ca}$ for the major cations and bicarbonate and sulfate as the only major anions) produces an average positive excess charge of 11 milliequivalents per liter. This calculation indicates that there is at least one other anion in the streamwater, possibly chloride. Chloride occurs in soluble halite in efflorescence deposits that occasionally occur on the streambank (see "Efflorescence" section) and, consequently, also would be in the streamwater. If the only other anion were chloride, it would require an average concentration of approximately $390 \mathrm{mg} / \mathrm{L}$ to equal the excess positive charge from the major cations. Note that this anion evaluation also indicates that sulfate is the dominant anion in these water samples, with an average concentration of $829 \mathrm{mg} / \mathrm{L}$, and that sulfate and bicarbonate together account for approximately two-thirds of the anions on an equivalence basis.

The solutions from the samples of raw water that were digested using heat and acidification were compared with filtered samples of the same water to determine if suspended solids contributed to constituent concentrations and thus loads in TGC under base-flow conditions sampled during December 2003 (table A1). For Se and U, there was less than a 6-percent difference between the two digested raw-water samples and their filtered counterparts, which indicates that suspended solids in the raw-water sample do not contribute to the loading of these trace elements in the streamwater during base-flow conditions. For $\mathrm{Cu}, \mathrm{Zn}$, and Mo, the digested raw concentrations were 1.2 to 3 times that of the filtered-water sample, which indicates there was a contribution to the concentrations of these elements in the streamwater by the suspended solids. Concentrations of $\mathrm{P}$ in the digested raw samples were elevated about fivefold and those for $\mathrm{Fe}$ and $\mathrm{Al}$ as much as fiftyfold over the filtered samples, which indicates that suspended solids in the stream contain major acid-soluble amounts of these elements during base-flow conditions.

\section{Selenium Load}

Selenium-load results are listed in table A1 and shown in figure 6. Selenium loads ranged from less than $6 \mathrm{~g} / \mathrm{d}$ at ETGS-1 to $250 \mathrm{~g} / \mathrm{d}$ at TGS-1. Selenium load generally increased downstream along WTGS and TGC, and load decreased downstream along ETGC. Although the greatest Se concentration occurred at ETGS-1, the load at that site was small because the discharge was small. In addition, despite the elevated Se concentrations in the outfall (OFS-1) the Se load was only about 18 percent of that in WTGS- 0.5 because of the small discharge of the outfall (table A1). Loads were greater in WTGC than in ETGC. The greatest increases in Se load occurred between WTGS-3 and WTGS-2 during both sampling events, and between TGS-2 and TGS-1 during the December 2003 sampling event, and to a lesser extent during the March 2004 sampling event. The load at TGS-2, downstream from the confluence of WTGC and ETGC was slightly greater than the sum of the loads at ETGC-1 and WTGC-0.5.

For the most part, the load profile shows that load consistently increased along WTGC and TGC during both sampling periods, supporting the hypothesis that ground-water discharge accounts for the elevated Se concentrations and increasing $\mathrm{Se}$ loads in TGC. Larger load increases between WTGS-3 and WTGS-2 during both sampling events and between TGS-2 and TGS-1 during the December 2003 sampling event may indicate possible point sources in these locations, or alternately, may indicate that ground water discharging to the stream in

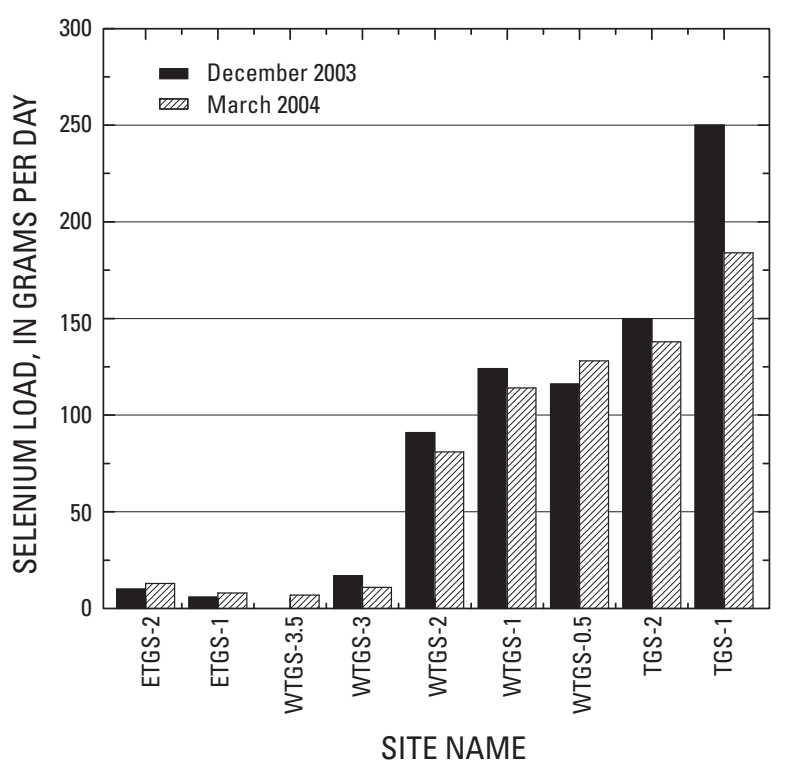

Figure 6. Selenium load profile along Toll Gate Creek for December 2003 and March 2004 sampling events. Results from Sand Creek and outfall sampling locations not included on this graph. 
these areas had greater Se concentrations than along the rest of the stream.

The progressive downstream increase in Se loads during both sampling events, particularly downstream from WTGS-2, indicates progressive addition of an element provided by and proportional to flow into the stream (fig. 7). The plot of load versus discharge yields a typical linear addition curve for an element with load proportional to inflow. Note that the December 2003 and March 2004 sampling events have different slopes, and the March 2004 measurements indicated slightly higher discharge and lower Se loads. The high values of $\mathrm{r}^{2}$, low p-values, and the lack of scatter about the regression lines, particularly at flow greater than $50 \mathrm{~L} / \mathrm{s}$ (all sites downstream

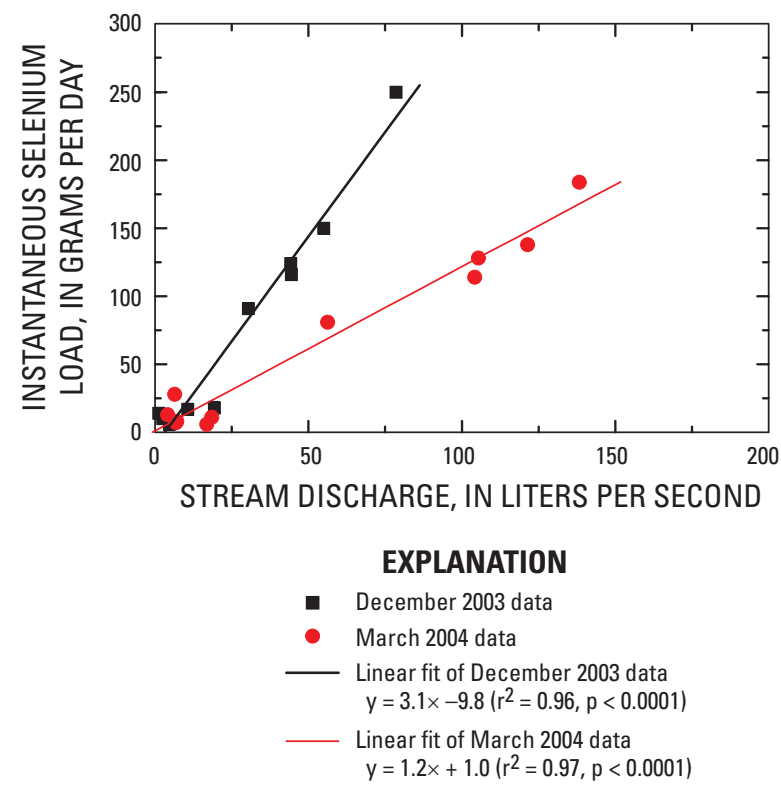

Figure 7. Selenium load and discharge and linear regressions for December 2003 and March 2004 sampling events. Results from Sand Creek and outfall sampling locations not included on this graph.

from and including WTGS-2), indicates that the amount of load being added per unit of flow increase is constant. If this amount were not constant, there would be greater scatter about the regression line and a lower value of $r^{2}$ and a greater $p$ value. During March 2004 sampling, snow on the ground had recently melted and likely added to shallow ground water, possibly producing the slightly higher flows and lower Se loads compared to the December 2003 sampling. Note that these regression relations cannot be used to predict concentrations in the stream at any location or any flow regime because the regressions were developed for a limited set of locations during generally low-flow conditions and do not encompass the complete range of conditions and locations on TGC. The high values of $r^{2}$ of the regressions illustrate that the load increases (per unit volume of flow increase) to WTGC and TGC particularly downstream from WTGS-2 were constant, which is evidence for discharge of ground water along that stream reach that had a relatively constant concentration of Se.

\section{Pearson Correlation Analysis}

Concentrations of elements in the water samples were tested for correlations using standard Pearson correlation methods. Correlation analysis requires numeric data sets. Hence, when some, but no more than one-third, of the reported values were non-numeric (that is censored, by being at or below the LLD), that variable was eliminated from the correlation subset. Duplicate samples were averaged to eliminate weighting bias, and samples taken at the same site but on different days were treated as separate samples. Elements with concentrations less than the LLD had those values replaced with 0.7 of the LLD (Cohen, 1959). Most elements had complete data sets with no replacements, and Al, Co, and Mo had four or fewer, less than 12 percent, replaced values. However, 32 percent of the values for $\mathrm{Cd}$ and $\mathrm{Pb}$ and 50 percent of the values for As were replaced. For these elements, especially As, the associations should be considered tenuous. Observations in another seleniferous sedimentary rock system noted that a logarithmic transformation of the concentration data better normalized the data set (Herring, 2004). Here, however, because of the limited number of observations, concentration data were not transformed. Correlations greater than 0.7 are in boldface type (table 4 ). This degree of correlation is significant at $\mathrm{p}<0.005$.

In the TGC water samples, Se significantly associates with the major phases $\mathrm{SO}_{4}, \mathrm{~K}, \mathrm{Ca}, \mathrm{Ti}$, and with the trace elements $\mathrm{Cu}, \mathrm{Sr}$, and $\mathrm{U}$ (table 4). The Se associations with $\mathrm{Na}$ and conductivity have strong but slightly less significant correlation coefficients. Selenium correlations with $\mathrm{Ca}$ and $\mathrm{Na}$ indicate a soluble host mineral phase with these elements as dominant cations. The association with sulfate indicates that this possibly is a dominant anion in those minerals. The apparent significant association in TGC waters between Se and K is anomalous. In water leachates of seleniferous marine shale of the Phosphoria Formation, Se does not strongly correlate with $\mathrm{K}$ (Herring, 2004). In the water of TGC, the seeming significant correlation between these two elements is an artifact of two anomalous water samples. These samples, both from the outfall (OFS-1), have the highest concentrations of Se and K for all samples. The reason for the seeming correlation is that the calculation of the correlation coefficient overly weights the values of the outfall samples by the square of their distance from the center of mass of the data points. Because these two outfall samples are most distant from the center of mass, a seemingly significant linear correlation coefficient is generated. If the two outfall samples are removed from the data set, the correlation coefficient between Se and K reduces to 0.46 , which is not significant at $\mathrm{p}<0.005$. 
Table 4. Correlation coefficients among elements in Toll Gate Creek water samples.

[Sp. Cond., specific conductance; $\mathrm{Na}$, sodium; Mg, magnesium; $\mathrm{Al}$, aluminum; $\mathrm{Si}$, silicon; $\mathrm{P}$, phosphorus; $\mathrm{SO}_{4}$, sulfate; $\mathrm{K}$, potassium; Ca, calcium, Ti, titanium; $\mathrm{V}$, vanadium; Cr, chromium; Mn, manganese; $\mathrm{Co}$, cobalt; $\mathrm{Cu}$, copper; Se, selenium; Sr, strontium; Mo, molybdenum; $\mathrm{Cd}$, cadmium; $\mathrm{Ba}$, barium; $\mathrm{Pb}$, lead; $\mathrm{U}$, uranium; Bold indicates correlation coefficient is significant at $\mathrm{p}$ less than 0.005$]$

\begin{tabular}{|c|c|c|c|c|c|c|c|c|c|c|c|c|c|c|c|c|c|c|c|c|c|}
\hline Element & $\begin{array}{l}\text { Sp. } \\
\text { Cond. }\end{array}$ & $\mathrm{Na}$ & Mg & Al & Si & $\mathbf{P}$ & $\mathrm{SO}_{4}$ & K & $\mathrm{Ca}$ & $\mathrm{Ti}$ & V & $\mathrm{Cr}$ & Mn & Co & $\mathrm{Cu}$ & Se & $\mathrm{Sr}$ & Mo & Cd & $\mathrm{Ba}$ & $\mathbf{P b}$ \\
\hline $\mathrm{Na}$ & 0.98 & & & & & & & & & & & & & & & & & & & & \\
\hline $\mathrm{Mg}$ & 0.80 & 0.70 & & & & & & & & & & & & & & & & & & & \\
\hline $\mathrm{Al}$ & 0.14 & 0.18 & -0.07 & & & & & & & & & & & & & & & & & & \\
\hline $\mathrm{Si}$ & 0.37 & 0.31 & 0.47 & -0.61 & & & & & & & & & & & & & & & & & \\
\hline $\mathrm{P}$ & 0.08 & 0.11 & 0.01 & 0.43 & -0.26 & & & & & & & & & & & & & & & & \\
\hline $\mathrm{SO} 4$ & 0.84 & 0.82 & 0.63 & 0.18 & 0.45 & 0.03 & & & & & & & & & & & & & & & \\
\hline $\mathrm{K}$ & 0.51 & 0.49 & 0.47 & 0.03 & 0.60 & 0.28 & 0.63 & & & & & & & & & & & & & & \\
\hline $\mathrm{Ca}$ & 0.81 & 0.73 & 0.84 & -0.12 & 0.73 & -0.06 & 0.86 & 0.70 & & & & & & & & & & & & & \\
\hline $\mathrm{Ti}$ & 0.78 & 0.72 & 0.79 & -0.16 & 0.73 & -0.10 & 0.87 & 0.68 & 0.97 & & & & & & & & & & & & \\
\hline $\mathrm{V}$ & -0.41 & -0.37 & -0.52 & 0.46 & -0.61 & 0.46 & -0.37 & -0.29 & -0.61 & -0.65 & & & & & & & & & & & \\
\hline $\mathrm{Cr}$ & 0.58 & 0.53 & 0.60 & -0.53 & 0.78 & -0.30 & 0.48 & 0.43 & 0.68 & 0.67 & -0.50 & & & & & & & & & & \\
\hline $\mathrm{Mn}$ & 0.64 & 0.57 & 0.77 & 0.16 & -0.08 & -0.02 & 0.41 & -0.01 & 0.44 & 0.37 & -0.24 & 0.22 & & & & & & & & & \\
\hline Co & 0.68 & 0.64 & 0.71 & 0.20 & -0.16 & 0.11 & 0.46 & 0.00 & 0.41 & 0.36 & -0.17 & 0.21 & 0.96 & & & & & & & & \\
\hline $\mathrm{Cu}$ & 0.76 & 0.82 & 0.51 & 0.19 & 0.35 & 0.25 & 0.68 & 0.59 & 0.61 & 0.65 & -0.25 & 0.39 & 0.26 & 0.31 & & & & & & & \\
\hline $\mathrm{Se}$ & 0.66 & 0.66 & 0.43 & 0.09 & 0.57 & 0.02 & 0.89 & 0.74 & 0.78 & 0.83 & -0.31 & 0.45 & 0.06 & 0.10 & 0.74 & & & & & & \\
\hline $\mathrm{Sr}$ & 0.90 & 0.84 & 0.86 & -0.10 & 0.63 & -0.07 & 0.88 & 0.62 & 0.96 & 0.94 & -0.62 & 0.69 & 0.57 & 0.56 & 0.65 & 0.73 & & & & & \\
\hline Mo & 0.07 & 0.13 & -0.10 & 0.33 & -0.33 & -0.01 & 0.12 & -0.41 & -0.10 & -0.04 & 0.17 & -0.21 & 0.10 & 0.14 & 0.20 & 0.04 & -0.05 & & & & \\
\hline $\mathrm{Cd}$ & 0.73 & 0.82 & 0.46 & 0.25 & 0.12 & 0.24 & 0.49 & 0.37 & 0.43 & 0.43 & -0.31 & 0.28 & 0.40 & 0.44 & 0.80 & 0.38 & 0.56 & 0.20 & & & \\
\hline $\mathrm{Ba}$ & 0.38 & 0.37 & 0.44 & -0.57 & 0.56 & -0.42 & 0.18 & 0.06 & 0.45 & 0.44 & -0.76 & 0.60 & 0.27 & 0.20 & 0.15 & 0.04 & 0.50 & -0.06 & 0.37 & & \\
\hline $\mathrm{Pb}$ & 0.23 & 0.35 & 0.00 & 0.45 & -0.27 & 0.35 & 0.05 & 0.12 & -0.11 & -0.09 & 0.08 & -0.22 & 0.17 & 0.19 & 0.49 & 0.04 & 0.03 & 0.24 & 0.67 & -0.08 & \\
\hline $\mathrm{U}$ & 0.68 & 0.66 & 0.53 & 0.08 & 0.54 & 0.04 & 0.82 & 0.79 & 0.77 & 0.75 & -0.30 & 0.53 & 0.24 & 0.25 & 0.68 & 0.80 & 0.76 & -0.10 & 0.47 & 0.11 & 0.17 \\
\hline
\end{tabular}




\section{Selenium and Other Trace Elements in Solid Samples}

Results from sampling and analysis of solid samples were used to help determine a mineralogic or bedrock source for the Se that occurs throughout TGC.

\section{Selenium in Solid Samples}

Element LLD and element concentration data for the sampled rocks and unconsolidated sediment are listed in table 3. Selenium in the solid samples generally had concentrations at or only moderately elevated above the EDXRF LLD of 1 ppm (table 3). Only 9 of 21 solid samples had a detectable Se concentration that exceeded the LLD. Most channel samples through the streambank were at or below the LLD. The Se concentrations of two sandstone-bedrock samples from the bottom of the stream channel of TGC ( 2 and $3 \mathrm{ppm}$ ) were greater than the mean of about $0.1 \mathrm{ppm}$ that is reported for various sandstone samples in the conterminous U.S. (Connor and Shacklette, 1975). Samples of stream sediment and of anoxic mud from within the stream channel contained 4 and $5 \mathrm{ppm} \mathrm{Se}$, respectively. The largest concentrations of Se in the solid samples were in a white efflorescent material that occurred along some of the streambank above water level. Three samples of the efflorescence had bulk Se concentrations that ranged from 3 to $25 \mathrm{ppm}$.

In the solid samples, Se was less than the detection limit for 12 of 21 samples. This poor detection ratio precludes a Pearson correlation analysis.

Nearby sedimentary rock and unconsolidated sediment samples that are listed in the USGS National Geochemical Database (NGD) (http://minerals.cr.usgs.gov/projects/ geochem_database/index.html, accessed, July 2006) show some slightly elevated Se concentrations relative to average samples for the conterminous United States. The average Se concentration in local soil is $0.3 \mathrm{ppm}$, although a few samples had concentrations of $2 \mathrm{ppm}$ as compared to surface horizon cultivated and uncultivated soil samples taken throughout Colorado that averaged $0.23 \mathrm{ppm}$ Se (Connor and Shacklette, 1975). Also, a sample of a continental low-grade coal seam taken from near Quincy Reservoir contained $2.4 \mathrm{ppm} \mathrm{Se}$, and a mudstone sample from about $50 \mathrm{~m}$ depth in a drill hole about $10 \mathrm{~km}$ to the northeast of the TGC drainage basin contained 9 ppm Se. These concentrations are similar to the concentrations reported for samples collected during this study.

\section{Concentration of Elements in Leachate}

Element concentration data from 20:1 (mass water: mass solid) leachates are listed in table 5. Leachate salinity (conductivity) ranged from 1 to 26 millisiemens per centimeter at 25 degrees Celsius $(\mathrm{mS} / \mathrm{cm})$ and was several times that of the streamwater samples. Specifically, leachates from the efflorescence samples had specific-conductance values greater than $15 \mathrm{mS} / \mathrm{cm}$, roughly one-third that of seawater, with $\mathrm{Na}$ concentrations near to or exceeding $5,000 \mathrm{mg} / \mathrm{L}$ and $\mathrm{SO}_{4}$ concentrations ranging from 7,870 to $17,200 \mathrm{mg} / \mathrm{L}$. Note that the concentrations of some major ions $\left(\mathrm{Na}, \mathrm{Mg}\right.$, and $\mathrm{SO}_{4}$ ) in leachate solutions from WTGS/R2.2A and WTGS/R3.5A greatly exceeded typical water concentrations of these elements in TGC. In addition, because the concentrations of these major elements were much greater in the leachate solutions than in TGC water samples, and other major elements ( $\mathrm{Ca}$ and $\mathrm{K}$ ) had similar concentrations in the leachate solutions and TGC water samples, the efflorescence probably is not evaporated from the capillary fringe of the stream, but rather from water having a different composition than the streamwater-ground water entering the stream. If the efflorescence formed by evaporation of streamwater, element ratios, or relative concentrations of major elements in the streamwater and the efflorescence would be similar. They are not.

In water leachates of the efflorescence, several elements $\left(\mathrm{SO}_{4}, \mathrm{Se}, \mathrm{Na}, \mathrm{V}, \mathrm{As}, \mathrm{Cu}, \mathrm{Mo}\right.$, and $\left.\mathrm{Pb}\right)$ and conductivity were enriched at least sixfold over streamwater samples. Selenium in leachate from efflorescence samples ranged from 146 to $1,460 \mu \mathrm{g} / \mathrm{L}$. Comparing the amount of Se in the leachate with that known to be in the solid sample (table 3), all Se in the efflorescence was water extractable within the 30-minute extraction time used for these experiments. However, even these elevated Se concentrations were a tiny fraction of the $\mathrm{SO}_{4}$ concentration in the leachate solutions and in the streamwater (table A1). Molar $\mathrm{SO}_{4} / \mathrm{Se}$ ratios range from about 3,000 to 64,000 in the leachates and from about 10,000 to 69,000 in the streamwater.

\section{Efflorescence}

X-ray diffraction analysis of one efflorescence sample indicated that it was composed of thenardite $\left(\mathrm{NaSO}_{4}\right)$, gypsum, and minor halite, in addition to minor silicate minerals from the rock substrate underlying the efflorescence that were included during sampling.

The solubility of the Se in this material indicates that the efflorescence would release considerable Se into streamwater during snowmelt or rain along the streambanks or during higher water levels associated with seasonal changes in flow.

An approximate evaluation of the possible contribution of the efflorescence material to the Se load in TGC basin indicates that the efflorescence, though an important contributor of Se to the streamwater, is insufficient to supply a Se load of $250 \mathrm{~g} / \mathrm{d}$ if that load is maintained throughout the year. A daily Se load of $250 \mathrm{~g}$ in TGC requires the dissolution of 10 tons of the efflorescence material with a concentration of 25 ppm Se. If an average mass per unit area of this material as exposed on the streambank face is assumed to be about $1 \mathrm{~g}$ per $100 \mathrm{~cm}^{2}$, dissolution of an amount of efflorescence to produce the daily load of $250 \mathrm{~g}$ would require an exposure of about $10^{5} \mathrm{~m}^{2}$ of efflorescence along the streambanks. Continuing the 
Table 5. Composition of water leachate and digestions of various rock and unconsolidated rock samples, Toll Gate Creek.

[TDS, total dissolved solids; ORP, oxidation-reduction potential; EDXRF, energy dispersive X-ray fluorescence; ICP-MS, inductively coupled plasma-mass spectrometry, ICP, inductively coupled plasma; $\mathrm{mS} / \mathrm{cm}$, millisiemens per centimeter; ppt, parts per thousand; $\mathrm{mV}$, millivolts; $\mathrm{mg} / \mathrm{L}$, milligram per liter; $\mathrm{CaCO}_{3}$, calcium carbonate; $\mu \mathrm{g} / \mathrm{L}$, micrograms per liter; ppm, parts per million; Min., minimum; Pct., percent; ck., creek; Se, selenium; Li, lithium; Be, beryllium; $\mathrm{Na}$, sodium; $\mathrm{Mg}$, magnesium; $\mathrm{Al}$, aluminum; $\mathrm{Si}$, silicon; $\mathrm{P}$, phosphorus; $\mathrm{SO}_{4}$, sulfate; $\mathrm{K}$, potassium, Ca, calcium; $\mathrm{Sc}$, scandium, Ti, titanium; V, vandium; Cr, chromium; Mn, manganese; Fe, iron; Co, cobalt; Ni, nickel; Cu, copper; Zn, zinc; Ga, gallium; Ge, germanium; As, arsenic; Rb, rubidium; Sr, strontium; Y, yttrium,; Zr, zirconium; Nb, niobium; Mo, molybdenum; Cd, cadmium; Sb, antimony; Cs, cesium; Ba, barium; La, lanthanum; Ce, cerium; W, tungsten; Tl, thallium; Pb, lead; Bi, bismuth; Th, thorium; $\mathrm{U}$, uranium; $\mathrm{H}_{2} \mathrm{O}$, water; $\mathrm{HNO}_{3}$, nitric acid, <, less than; -, no value]

\begin{tabular}{|c|c|c|c|c|c|c|c|c|c|}
\hline Sample & Procedure & $\begin{array}{c}\text { Specific } \\
\text { conductance } \\
\text { (mS/cm) }\end{array}$ & $\begin{array}{l}\text { TDS } \\
\text { (ppt) }\end{array}$ & $\mathrm{pH}$ & $\begin{array}{l}\text { ORP } \\
(\mathrm{mV})\end{array}$ & $\begin{array}{c}\text { Alkalinity } \\
\text { (mg/L } \\
\left.\mathrm{CaCO}_{3}\right)\end{array}$ & $\begin{array}{c}\text { EDXRF } \\
\text { Se } \\
(\mathrm{ppm})\end{array}$ & $\begin{array}{c}\text { ICP-MS } \\
\text { Se Leach } \\
(\mu \mathrm{g} / \mathrm{L})\end{array}$ & $\begin{array}{r}\text { Amount Se } \\
\text { extracted } \\
\text { (percent) }\end{array}$ \\
\hline Lower Limit of Detection & & & & & & & & 1 & - \\
\hline WTGS/R-1.4B efflorescence & 20:1 $\mathrm{H}_{2} \mathrm{O}$ Leachate & - & - & - & - & - & 25 & 1,460 & 117 \\
\hline WTGS/R-2.2B anoxic mud & $\mathrm{HNO}_{3}$ Digest & - & - & - & - & - & 5 & 111 & 44 \\
\hline WTGS/R-2.2A efflorescence & 20:1 $\mathrm{H}_{2} \mathrm{O}$ Leachate & 17.94 & 10.61 & 6.4 & - & - & 3 & 146 & 97 \\
\hline WTGS/R-3.5A efflorescence & 20:1 $\mathrm{H}_{2} \mathrm{O}$ Leachate & 25.55 & 15.48 & 6.85 & - & - & 4 & 241 & 121 \\
\hline WTGS/R-1.4B efflorescence & 20:1 $\mathrm{H}_{2} \mathrm{O}$ Leachate & 18.56 & 11.02 & 7.19 & - & - & 25 & 1,360 & 109 \\
\hline WTGS/R-2.2A efflorescence & 20:1 $\mathrm{H}_{2} \mathrm{O}$ Leachate & 16.7 & 9.793 & 6.71 & 111 & 28 & 3 & 164 & 109 \\
\hline WTGS/R-3.5A efflorescence & 20:1 $\mathrm{H}_{2} \mathrm{O}$ Leachate & 26.57 & 16.18 & 7.68 & 85 & 45 & 4 & 255 & 128 \\
\hline
\end{tabular}


[TDS, total dissolved solids; ORP, oxidation-reduction potential; EDXRF, energy dispersive X-ray fluorescence; ICP-MS, inductively coupled plasma-mass spectrometry, ICP, inductively coupled plasma; $\mathrm{mS} / \mathrm{cm}$, millisiemens per centimeter; ppt, parts per thousand; mV, millivolts; $\mathrm{mg} / \mathrm{L}$, milligram per liter; $\mathrm{CaCO}_{3}$, calcium carbonate; $\mu \mathrm{g} / \mathrm{L}$, micrograms per liter; ppm, parts per million; Min., minimum; Pct., percent; ck., creek; Se, selenium; Li, lithium; Be, beryllium; Na, sodium; Mg, magnesium; Al, aluminum; Si, silicon; $\mathrm{P}$, phosphorus; $\mathrm{SO}_{4}$, sulfate; $\mathrm{K}$, potassium, Ca, calcium; Sc, scandium, Ti, titanium; V,

vandium; Cr, chromium; Mn, manganese; Fe, iron; Co, cobalt; Ni, nickel; Cu, copper; Zn, zinc; Ga, gallium; Ge, germanium; As, arsenic; Rb, rubidium; Sr, strontium; Y, yttrium,; Zr, zirconium; Nb, niobium; Mo, molybdenum; Cd, cadmium; Sb, antimony; Cs, cesium; Ba, barium; La, lanthanum; Ce, cerium; W, tungsten; $\mathrm{Tl}$, thallium; $\mathrm{Pb}$, lead; $\mathrm{Bi}$, bismuth; $\mathrm{Th}$, thorium; $\mathrm{U}$, uranium; $\mathrm{H}_{2} \mathrm{O}$, water; $\mathrm{HNO}{ }_{3}$, nitric acid, $<$, less than; -, no value]

\begin{tabular}{|c|c|c|c|c|c|c|c|c|c|c|}
\hline Sample & Procedure & $\begin{array}{c}\text { ICP } \\
\mathrm{SO}_{4} \\
\text { (mg/L) }\end{array}$ & $\begin{array}{l}\text { Min. } \\
\text { pct. } \\
\mathrm{SO}_{4} \text { in } \\
\text { solid } \\
\text { sample }\end{array}$ & $\begin{array}{l}\text { Molar } \\
\mathrm{SO}_{4} \text { se }\end{array}$ & $\begin{array}{c}\text { Pct. } \\
\text { solid } \\
\text { soluble }\end{array}$ & $\begin{array}{c}\mathbf{L i} \\
(\mu \mathrm{g} / \mathrm{L})\end{array}$ & $\begin{array}{c}\mathrm{Be} \\
(\mu \mathrm{g} / \mathrm{L})\end{array}$ & $\underset{(\mathrm{mg} / \mathrm{L})}{\mathrm{Na}}$ & $\underset{\text { (mg/L) }}{M g}$ & $\begin{array}{c}\text { Al } \\
(\mu \mathrm{g} / \mathrm{L})\end{array}$ \\
\hline Lower Limit of Detection & & 2 & - & - & - & 0.9 & 0.05 & 0.5 & 0.01 & 2 \\
\hline WTGS/R-1.4B efflorescence & 20:1 $\mathrm{H}_{2} \mathrm{O}$ Leachate & 9,970 & 20 & 5,617 & - & 28.3 & 0.07 & 5,020 & 69.7 & 26.4 \\
\hline WTGS/R-2.2B anoxic mud & $\mathrm{HNO}_{3}$ Digest & 893 & 2 & 6,617 & - & 114 & 17.7 & 53.6 & 120 & 99,000 \\
\hline TGS/R-2.1A rock bottom in ck. & $\mathrm{HNO}_{3}$ Digest & 124 & 0.2 & 2,825 & - & 134 & 40.8 & 63.0 & 108 & 153,000 \\
\hline WTGS/R-2.2A efflorescence & 20:1 $\mathrm{H}_{2} \mathrm{O}$ Leachate & 11,300 & 23 & 63,659 & 21 & 34.7 & 0.09 & - & 174 & 203 \\
\hline WTGS/R-3.5A efflorescence & 20:1 $\mathrm{H}_{2} \mathrm{O}$ Leachate & 17,200 & 34 & 58,701 & 31 & 22.4 & 0.08 & - & 262 & 15.9 \\
\hline WTGS/R-1.4B efflorescence & 20:1 $\mathrm{H}_{2} \mathrm{O}$ Leachate & 11,500 & 23 & 6,955 & 22 & 32.5 & $<0.05$ & - & 82.0 & 21.4 \\
\hline WTGS/R-2.2A efflorescence & 20:1 $\mathrm{H}_{2} \mathrm{O}$ Leachate & 8,320 & 17 & 41,727 & 20 & 33.2 & $<0.05$ & 4,380 & 149 & 58.0 \\
\hline WTGS/R-3.5A efflorescence & 20:1 $\mathrm{H}_{2} \mathrm{O}$ Leachate & 14,800 & 30 & 47,737 & 32 & $<0.9$ & 0.2 & 7,420 & 246 & 34.9 \\
\hline WTGS/R-2.2B anoxic mud & 20:1 $\mathrm{H}_{2} \mathrm{O}$ Leachate & 451 & 1 & 5,447 & 1 & $<0.9$ & $<0.05$ & 43.7 & 18.0 & 48.1 \\
\hline WTGS/R-1.4B efflorescence & 20:1 $\mathrm{H}_{2} \mathrm{O}$ Leachate & 7,870 & 16 & 5,780 & 20 & 5.1 & 0.8 & 4,390 & 66.3 & 43.1 \\
\hline
\end{tabular}


Table 5. Composition of water leachate and digestions of various rock and unconsolidated rock samples, Toll Gate Creek.-Continued

[TDS, total dissolved solids; ORP, oxidation-reduction potential; EDXRF, energy dispersive X-ray fluorescence; ICP-MS, inductively coupled plasma-mass spectrometry, ICP, inductively coupled plasma; $\mathrm{mS} / \mathrm{cm}$, millisiemens per centimeter; ppt, parts per thousand; mV, millivolts; mg/L, milligram per liter; $\mathrm{CaCO}_{3}$, calcium carbonate; $\mu \mathrm{g} / \mathrm{L}$, micrograms per liter; ppm, parts per million; Min., minimum; Pct., percent; ck., creek; Se, selenium; Li, lithium; Be, beryllium; Na, sodium; Mg, magnesium; Al, aluminum; $\mathrm{Si}$, silicon; $\mathrm{P}$, phosphorus; $\mathrm{SO}_{4}$, sulfate; K, potassium, Ca, calcium; Sc, scandium, Ti, titanium; V, vandium; Cr, chromium; Mn, manganese; Fe, iron; Co, cobalt; Ni, nickel; Cu, copper; Zn, zinc; Ga, gallium; Ge, germanium; As, arsenic; Rb, rubidium; Sr, strontium; Y, yttrium,; Zr, zirconium; Nb, niobium; Mo, molybdenum; Cd, cadmium; $\mathrm{Sb}$, antimony; $\mathrm{Cs}$, cesium; Ba, barium; La, lanthanum; Ce, cerium; $\mathrm{W}$, tungsten; $\mathrm{Tl}$, thallium; $\mathrm{Pb}$, lead; $\mathrm{Bi}$, bismuth; $\mathrm{Th}$, thorium; $\mathrm{U}$, uranium; $\mathrm{H}_{2} \mathrm{O}$, water; $\mathrm{HNO}{ }_{3}$, nitric acid,

$<$, less than; -, no value]

\begin{tabular}{|c|c|c|c|c|c|c|c|c|c|c|c|}
\hline Sample & Procedure & $\begin{array}{c}\mathbf{S i} \\
(\mathbf{m g} / \mathbf{L})\end{array}$ & $\underset{(\mathrm{mg} / \mathrm{L})}{P}$ & $\begin{array}{c}\mathrm{K} \\
\text { (mg/L) }\end{array}$ & $\begin{array}{c}\mathrm{Ca} \\
\text { (mg/L) }\end{array}$ & $\begin{array}{c}\text { Sc } \\
(\mu \mathbf{g} / \mathbf{L})\end{array}$ & $\begin{array}{c}\mathrm{Ti} \\
(\mu \mathrm{g} / \mathrm{L})\end{array}$ & $\begin{array}{c}\mathbf{V} \\
(\mu \mathbf{g} / \mathbf{L})\end{array}$ & $\begin{array}{c}\mathbf{C r} \\
(\mu \mathbf{g} / \mathbf{L})\end{array}$ & $\begin{array}{c}\text { Mn } \\
(\mu \mathbf{g} / \mathbf{L})\end{array}$ & $\begin{array}{c}\text { Fe } \\
(\mu \mathbf{g} / \mathbf{L})\end{array}$ \\
\hline Lower Limit of Detection & & 0.2 & 0.01 & 0.03 & 0.2 & 0.6 & 0.5 & 0.5 & 1 & 0.2 & 50 \\
\hline WTGS/R-1.4B efflorescence & 20:1 $\mathrm{H}_{2} \mathrm{O}$ Leachate & $<0.2$ & 0.1 & 6.21 & 336 & $<0.6$ & 197 & 8.6 & $<1$ & 17.3 & 164 \\
\hline WTGS/R-2.2B anoxic mud & $\mathrm{HNO}_{3}$ Digest & 95.4 & 42.2 & 20.8 & 7,920 & 51.5 & 501 & 555 & 148 & 38,600 & 443,000 \\
\hline TGS/R-2.1A rock bottom in ck. & $\mathrm{HNO}_{3}$ Digest & 124 & 66.5 & 22.4 & 1,700 & 55.6 & 781 & 275 & 24.8 & 78,200 & 195,000 \\
\hline WTGS/R-2.2A efflorescence & 20:1 $\mathrm{H}_{2} \mathrm{O}$ Leachate & 3.8 & 1.4 & 11.1 & 418 & $<0.6$ & 161 & 13.2 & 1.2 & 139 & 601 \\
\hline WTGS/R-3.5A efflorescence & 20:1 $\mathrm{H}_{2} \mathrm{O}$ Leachate & 3.8 & 0.7 & 9.97 & 430 & 1.3 & 277 & 16.0 & 1.5 & 31.5 & 331 \\
\hline WTGS/R-1.4B efflorescence & 20:1 $\mathrm{H}_{2} \mathrm{O}$ Leachate & 3.2 & 0.4 & 6.41 & 360 & 1.0 & 170 & 8.8 & $<1$ & 14.7 & 230 \\
\hline WTGS/R-2.2A efflorescence & 20:1 $\mathrm{H}_{2} \mathrm{O}$ Leachate & $<0.2$ & $<0.01$ & 9.76 & 373 & $<0.6$ & $<0.5$ & 44.9 & $<1$ & 64.6 & 398 \\
\hline WTGS/R-3.5A efflorescence & 20:1 $\mathrm{H}_{2} \mathrm{O}$ Leachate & $<0.2$ & $<0.01$ & 9.45 & 389 & $<0.6$ & 60.5 & 54.5 & $<1$ & 33.4 & $<50$ \\
\hline WTGS/R-2.2B anoxic mud & 20:1 $\mathrm{H}_{2} \mathrm{O}$ Leachate & $<0.2$ & $<0.01$ & 8.01 & 124 & $<0.6$ & $<0.5$ & 47.5 & $<1$ & 57.4 & $<50$ \\
\hline WTGS/R-1.4B efflorescence & 20:1 $\mathrm{H}_{2} \mathrm{O}$ Leachate & $<0.2$ & $<0.01$ & 6.02 & 307 & $<0.6$ & $<0.5$ & 47.7 & $<1$ & 14.4 & $<50$ \\
\hline
\end{tabular}

WTGS/R-1.4B efflorescence

20:1 $\mathrm{H}_{2} \mathrm{O}$ Leachate

307 
[TDS, total dissolved solids; ORP, oxidation-reduction potential; EDXRF, energy dispersive X-ray fluorescence; ICP-MS, inductively coupled plasma-mass spectrometry, ICP, inductively coupled plasma; $\mathrm{mS} / \mathrm{cm}$, millisiemens per centimeter; ppt, parts per thousand; mV, millivolts; $\mathrm{mg} / \mathrm{L}$, milligram per liter; $\mathrm{CaCO}_{3}$, calcium carbonate; $\mu \mathrm{g} / \mathrm{L}$, micrograms per liter; ppm, parts per million; Min., minimum; Pct., percent; ck., creek; Se, selenium; Li, lithium; Be, beryllium; Na, sodium; Mg, magnesium; Al, aluminum; Si, silicon; P, phosphorus; $\mathrm{SO}_{4}$, sulfate; K, potassium, Ca, calcium; Sc, scandium, Ti, titanium; V, vandium; Cr, chromium; Mn, manganese; Fe, iron; Co, cobalt; Ni, nickel; Cu, copper; Zn, zinc; Ga, gallium; Ge, germanium; As, arsenic; Rb, rubidium; Sr, strontium; Y, yttrium,; Zr, zirconium; Nb, niobium; Mo, molybdenum; Cd, cadmium; Sb, antimony; $\mathrm{Cs}$, cesium; $\mathrm{Ba}$, barium; La, lanthanum; Ce, cerium; W, tungsten; $\mathrm{Tl}$, thallium; $\mathrm{Pb}$, lead; $\mathrm{Bi}$, bismuth; $\mathrm{Th}$, thorium; $\mathrm{U}$, uranium; $\mathrm{H}_{2} \mathrm{O}$, water; $\mathrm{HNO}{ }_{3}$, nitric acid, $<$, less than; -, no value]

\begin{tabular}{|c|c|c|c|c|c|c|c|c|c|c|c|}
\hline Sample & Procedure & $\begin{array}{c}\text { Co } \\
(\mu \mathrm{g} / \mathrm{L})\end{array}$ & $\begin{array}{c}\mathbf{N i} \\
(\mu \mathbf{g} / \mathrm{L})\end{array}$ & $\underset{(\mu \mathbf{g} / \mathrm{L})}{\mathbf{C u}}$ & $\begin{array}{c}Z \mathbf{n} \\
(\mu \mathrm{g} / \mathrm{L})\end{array}$ & $\begin{array}{c}\text { Ga } \\
(\mu \mathbf{g} / \mathbf{L})\end{array}$ & $\begin{array}{c}\mathbf{G e} \\
(\mu \mathbf{g} / \mathbf{L})\end{array}$ & $\begin{array}{c}\text { As } \\
(\mu \mathrm{g} / \mathrm{L})\end{array}$ & $\begin{array}{c}\mathbf{R b} \\
(\mu \mathbf{g} / \mathbf{L})\end{array}$ & $\begin{array}{c}\text { Sr } \\
(\mu \mathrm{g} / \mathrm{L})\end{array}$ & $\begin{array}{c}\mathbf{Y} \\
(\mu \mathrm{g} / \mathrm{L})\end{array}$ \\
\hline Lower Limit of Detection & & 0.02 & 0.4 & 0.5 & 0.5 & 0.05 & 0.05 & 1 & 0.01 & 0.5 & 0.01 \\
\hline WTGS/R-1.4B efflorescence & 20:1 $\mathrm{H}_{2} \mathrm{O}$ Leachate & 1.06 & 8.0 & 24.8 & 10.8 & $<0.05$ & $<0.05$ & 62.2 & 3.36 & 11,300 & 0.70 \\
\hline WTGS/R-2.2B anoxic mud & $\mathrm{HNO}_{3}$ Digest & 203 & 152 & 2,580 & 2,430 & 36.6 & 2.2 & 95.5 & 59.9 & 55,600 & 308 \\
\hline TGS/R-2.1A rock bottom in ck. & $\mathrm{HNO}_{3}$ Digest & 286 & 159 & 575 & 2,190 & 49.4 & 3.4 & 34.4 & 237 & 15,300 & 720 \\
\hline WTGS/R-2.2A efflorescence & 20:1 $\mathrm{H}_{2} \mathrm{O}$ Leachate & 3.53 & 6.0 & 48.5 & 15.8 & 0.08 & 0.75 & 11.4 & 4.19 & 8,960 & 1.22 \\
\hline WTGS/R-3.5A efflorescence & 20:1 $\mathrm{H}_{2} \mathrm{O}$ Leachate & 1.67 & 9.0 & 43.7 & 26.2 & $<0.05$ & 0.90 & 18.7 & 4.38 & 8,860 & 0.58 \\
\hline WTGS/R-1.4B efflorescence & 20:1 $\mathrm{H}_{2} \mathrm{O}$ Leachate & 0.92 & 1.7 & 30.2 & 19.9 & $<0.05$ & 0.25 & 23.8 & 2.88 & 10,200 & 0.38 \\
\hline WTGS/R-2.2A efflorescence & 20:1 $\mathrm{H}_{2} \mathrm{O}$ Leachate & 2.44 & $<0.4$ & 44.2 & 189 & $<0.05$ & 1.4 & 20.3 & 3.56 & 7,970 & 0.14 \\
\hline WTGS/R-3.5A efflorescence & 20:1 $\mathrm{H}_{2} \mathrm{O}$ Leachate & 1.58 & 0.9 & 50.6 & 12.9 & $<0.05$ & 1.7 & 27.4 & 4.61 & 8,600 & 0.30 \\
\hline WTGS/R-2.2B anoxic mud & 20:1 $\mathrm{H}_{2} \mathrm{O}$ Leachate & 1.35 & 0.9 & 50.5 & $<0.5$ & $<0.05$ & 1.0 & 2 & 3.49 & 1,570 & 0.06 \\
\hline WTGS/R-1.4B efflorescence & 20:1 $\mathrm{H}_{2} \mathrm{O}$ Leachate & 0.56 & $<0.4$ & 26.5 & $<0.5$ & $<0.05$ & 1.8 & 7.5 & 2.41 & 9,470 & 0.10 \\
\hline
\end{tabular}


Table 5. Composition of water leachate and digestions of various rock and unconsolidated rock samples, Toll Gate Creek.-Continued

[TDS, total dissolved solids; ORP, oxidation-reduction potential; EDXRF, energy dispersive X-ray fluorescence; ICP-MS, inductively coupled plasma-mass spectrometry, ICP, inductively coupled plasma; $\mathrm{mS} / \mathrm{cm}$, millisiemens per centimeter; ppt, parts per thousand; mV, millivolts; mg/L, milligram per liter; $\mathrm{CaCO}_{3}$, calcium carbonate; $\mu \mathrm{g} / \mathrm{L}$, micrograms per liter; ppm, parts per million; Min., minimum; Pct., percent; ck., creek; Se, selenium; Li, lithium; Be, beryllium; Na, sodium; Mg, magnesium; Al, aluminum; Si, silicon; $\mathrm{P}$, phosphorus; $\mathrm{SO}_{4}$, sulfate; $\mathrm{K}$, potassium, Ca, calcium; Sc, scandium, Ti, titanium; V, vandium; $\mathrm{Cr}$, chromium; Mn, manganese; Fe, iron; Co, cobalt; Ni, nickel; Cu, copper; $\mathrm{Zn}$, zinc; Ga, gallium; Ge, germanium; As, arsenic; Rb, rubidium; Sr, strontium; Y, yttrium,; Zr, zirconium; $\mathrm{Nb}$, niobium; Mo, molybdenum; Cd, cadmium; $\mathrm{Sb}$, antimony; $\mathrm{Cs}$, cesium; $\mathrm{Ba}$, barium; La, lanthanum; $\mathrm{Ce}$, cerium; $\mathrm{W}$, tungsten; $\mathrm{Tl}$, thallium; $\mathrm{Pb}$, lead; $\mathrm{Bi}$, bismuth; $\mathrm{Th}$, thorium; $\mathrm{U}$, uranium; $\mathrm{H}_{2} \mathrm{O}$, water; $\mathrm{HNO}{ }_{3}$, nitric acid, $<$, less than; -, no value]

\begin{tabular}{|c|c|c|c|c|c|c|c|c|c|c|c|}
\hline Sample & Procedure & $\begin{array}{c}\mathrm{Zr} \\
(\mu \mathrm{g} / \mathrm{L})\end{array}$ & $\begin{array}{c}\mathbf{N b} \\
(\mu \mathrm{g} / \mathrm{L})\end{array}$ & $\begin{array}{c}\text { Mo } \\
(\mu \mathrm{g} / \mathrm{L})\end{array}$ & $\begin{array}{c}\text { Cd } \\
(\mu \mathrm{g} / \mathrm{L})\end{array}$ & $\begin{array}{c}\text { Sb } \\
(\mu \mathrm{g} / \mathrm{L})\end{array}$ & $\begin{array}{c}\text { Cs } \\
(\mu \mathbf{g} / \mathrm{L})\end{array}$ & $\begin{array}{c}\text { Ba } \\
(\mu \mathrm{g} / \mathrm{L})\end{array}$ & $\begin{array}{c}\text { La } \\
(\mu \mathbf{g} / \mathbf{L})\end{array}$ & $\begin{array}{c}\text { Ce } \\
(\mu \mathrm{g} / \mathrm{L})\end{array}$ & $\begin{array}{c}\mathbf{W} \\
(\mu \mathbf{g} / \mathrm{L})\end{array}$ \\
\hline Lower Limit of Detection & & 0.2 & 0.2 & 2 & 0.02 & 0.3 & 0.02 & 0.2 & 0.01 & 0.01 & 0.5 \\
\hline WTGS/R-1.4B efflorescence & 20:1 $\mathrm{H}_{2} \mathrm{O}$ Leachate & 0.2 & 1.64 & 20.8 & 0.09 & 0.70 & 0.03 & 74.0 & 0.02 & 0.05 & 1.20 \\
\hline WTGS/R-2.2B anoxic mud & $\mathrm{HNO}_{3}$ Digest & 44.2 & $<0.2$ & 13.3 & 11.0 & 1.19 & 2.24 & 5,250 & 375 & 892 & 1.87 \\
\hline TGS/R-2.1A rock bottom in ck. & $\mathrm{HNO}_{3}$ Digest & 19.9 & $<0.2$ & 4.3 & 14.9 & 0.68 & 11.1 & 6,120 & 993 & 2200 & 1.37 \\
\hline WTGS/R-2.2A efflorescence & 20:1 $\mathrm{H}_{2} \mathrm{O}$ Leachate & 3.0 & $<0.2$ & 11.6 & 0.23 & 0.88 & 0.02 & 43.6 & 1.10 & 2.48 & 1.45 \\
\hline WTGS/R-3.5A efflorescence & 20:1 $\mathrm{H}_{2} \mathrm{O}$ Leachate & 2.8 & $<0.2$ & 73.6 & 0.20 & 0.52 & 0.05 & 57.7 & 0.06 & 0.24 & 0.93 \\
\hline WTGS/R-1.4B efflorescence & 20:1 $\mathrm{H}_{2} \mathrm{O}$ Leachate & 0.97 & $<0.2$ & 21.4 & 0.10 & 0.42 & $<0.02$ & 57.7 & 0.02 & 0.04 & 0.71 \\
\hline WTGS/R-2.2A efflorescence & 20:1 $\mathrm{H}_{2} \mathrm{O}$ Leachate & 1.8 & 16.8 & 39.0 & $<0.02$ & 6.82 & 0.15 & 33.2 & 0.08 & $<0.01$ & 6.06 \\
\hline WTGS/R-3.5A efflorescence & 20:1 $\mathrm{H}_{2} \mathrm{O}$ Leachate & 2.4 & 15.3 & 80.9 & 0.10 & 3.92 & 0.16 & 59.3 & 0.07 & 0.06 & 5.54 \\
\hline WTGS/R-2.2B anoxic mud & 20:1 $\mathrm{H}_{2} \mathrm{O}$ Leachate & 0.94 & 12.1 & 17.9 & $<0.02$ & 2.54 & 0.07 & 47.3 & $<0.01$ & $<0.01$ & 4.06 \\
\hline WTGS/R-1.4B efflorescence & 20:1 $\mathrm{H}_{2} \mathrm{O}$ Leachate & 1.2 & 12.2 & 25.9 & $<0.02$ & 2.00 & 0.08 & 61.0 & $<0.01$ & $<0.01$ & 3.47 \\
\hline
\end{tabular}


Table 5. Composition of water leachate and digestions of various rock and unconsolidated rock samples, Toll Gate Creek.-Continued

[TDS, total dissolved solids; ORP, oxidation-reduction potential; EDXRF, energy dispersive X-ray fluorescence; ICP-MS, inductively coupled plasma-mass spectrometry, ICP, inductively coupled plasma; $\mathrm{mS} / \mathrm{cm}$, millisiemens per centimeter; ppt, parts per thousand; $\mathrm{mV}$, millivolts; mg/L, milligram per liter; $\mathrm{CaCO}_{3}$, calcium carbonate; $\mu \mathrm{g} / \mathrm{L}$, micrograms per liter; ppm, parts per million; Min., minimum; Pct., percent; ck., creek; Se, selenium; Li, lithium; Be, beryllium; $\mathrm{Na}$, sodium; $\mathrm{Mg}$, magnesium; $\mathrm{Al}$, aluminum; $\mathrm{Si}$, silicon; $\mathrm{P}$, phosphorus; $\mathrm{SO}_{4}$, sulfate; $\mathrm{K}$, potassium, Ca, calcium; Sc, scandium, Ti, titanium; V, vandium; Cr, chromium; Mn, manganese; Fe, iron; Co, cobalt; Ni, nickel; $\mathrm{Cu}$, copper; Zn, zinc; Ga, gallium; Ge, germanium; As, arsenic; Rb, rubidium; Sr, strontium; Y, yttrium,; Zr, zirconium; Nb, niobium; Mo, molybdenum; Cd, cadmium; Sb, antimony; Cs, cesium; Ba, barium; La, lanthanum; Ce, cerium; W, tungsten; Tl, thallium; $\mathrm{Pb}$, lead; $\mathrm{Bi}$, bismuth; Th, thorium; $\mathrm{U}$, uranium; $\mathrm{H}_{2} \mathrm{O}$, water; $\mathrm{HNO}_{3}$, nitric acid, <, less than; -, no value]

\begin{tabular}{|c|c|c|c|c|c|c|}
\hline Sample & Procedure & $\begin{array}{c}\text { TI } \\
(\mu \mathrm{g} / \mathrm{L})\end{array}$ & $\begin{array}{c}\mathrm{Pb} \\
(\mu \mathrm{g} / \mathrm{L})\end{array}$ & $\begin{array}{c}\mathbf{B i} \\
(\mu \mathbf{g} / \mathbf{L})\end{array}$ & $\begin{array}{c}\text { Th } \\
(\mu \mathrm{g} / \mathrm{L})\end{array}$ & $\begin{array}{c}\mathbf{U} \\
(\mu \mathbf{g} / \mathbf{L})\end{array}$ \\
\hline Lower Limit of Detection & & 0.1 & 0.05 & 0.2 & 0.2 & 0.1 \\
\hline WTGS/R-1.4B efflorescence & 20:1 $\mathrm{H}_{2} \mathrm{O}$ Leachate & $<0.1$ & 0.2 & $<0.2$ & 0.40 & 15.6 \\
\hline WTGS/R-2.2B anoxic mud & $\mathrm{HNO}_{3}$ Digest & 0.88 & 390 & 1.23 & 47.6 & 175 \\
\hline TGS/R-2.1A rock bottom in ck. & $\mathrm{HNO}_{3}$ Digest & 0.4 & 473 & 1.16 & 21.0 & 53.3 \\
\hline WTGS/R-2.2A efflorescence & 20:1 $\mathrm{H}_{2} \mathrm{O}$ Leachate & $<0.1$ & 0.68 & $<0.2$ & 0.74 & 3.18 \\
\hline WTGS/R-3.5A efflorescence & 20:1 $\mathrm{H}_{2} \mathrm{O}$ Leachate & $<0.1$ & 0.06 & $<0.2$ & $<0.2$ & 82.4 \\
\hline WTGS/R-1.4B efflorescence & 20:1 $\mathrm{H}_{2} \mathrm{O}$ Leachate & $<0.1$ & $<0.05$ & $<0.2$ & $<0.2$ & 10.3 \\
\hline WTGS/R-2.2A efflorescence & 20:1 $\mathrm{H}_{2} \mathrm{O}$ Leachate & 3.2 & 1.2 & 4.11 & 1.15 & 3.31 \\
\hline WTGS/R-3.5A efflorescence & 20:1 $\mathrm{H}_{2} \mathrm{O}$ Leachate & 1.6 & 0.4 & 1.93 & 1.14 & 91.2 \\
\hline WTGS/R-2.2B anoxic mud & 20:1 $\mathrm{H}_{2} \mathrm{O}$ Leachate & 0.91 & 0.3 & 1.20 & 0.47 & 5.45 \\
\hline WTGS/R-1.4B efflorescence & 20:1 $\mathrm{H}_{2} \mathrm{O}$ Leachate & 0.77 & 0.3 & 0.78 & 0.56 & 10.2 \\
\hline
\end{tabular}

approximation, if the typical efflorescence zone along the streambank is one-half meter in height (figs. 3 and 8), a 20-km length of streambank efflorescence would have to dissolve each day to supply the observed daily load. This would constitute a significant fraction of the total length of all reaches of TGC. Based on field observation, the amount of streambank with efflorescence is estimated to be 5 percent or less, therefore it is not possible for dissolution of the efflorescence to supply the observed Se loads to the stream.

The source of the Se in this efflorescence material is unknown, but it likely results from movement of ground water through rock with relatively low but leachable Se content, discharge of this ground water along the streambank, evaporation of some of the water on the face of the streambank, and concentration of the Se into the resulting evaporite minerals. Alternatively, the efflorescence could originate from percolation and evaporation of Se-laden streamwater that saturates the bank during high flow in the stream then seeps back toward the stream during lower flow. However, if this were the case, the streambanks would have relatively uniform coverage of the efflorescence, and this is not the case. In addition, if the efflorescence originated from streamwater, it should have similar element ratios to streamwater, and as described in a previous section ("Concentration of Elements in Leachate"), it does not.

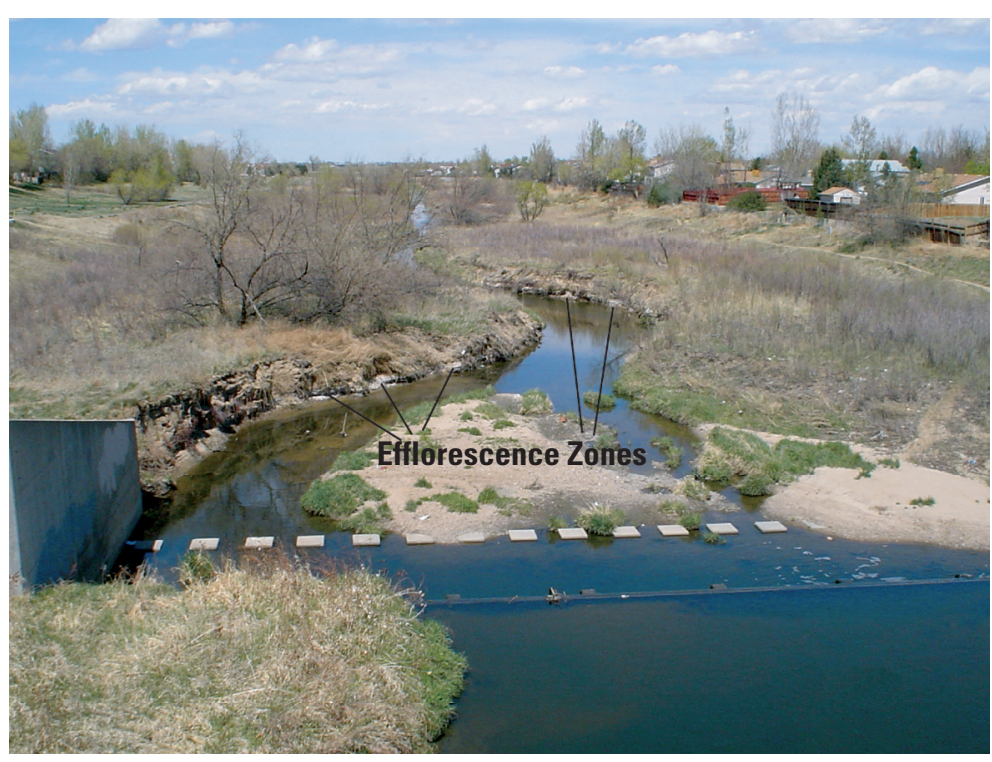

Figure 8. View of efflorescence zones along West Toll Gate Creek directly north of Mississippi Street overpass. 
Efflorescence on the bank has an irregular occurrence, which is more consistent with the seepage of Se-laden ground water through rock and discharge along permeable zones of the bank.

\section{Implications Regarding Selenium Sources, Remediation, and Future Work}

The results of this study can be used to discuss possible sources of Se to TGC, possible remediation strategies for the elevated Se concentrations, and directions for future work. The discussion presented in this section arose from interpretation of the scientific data presented herein and is not intended to be an official recommendation by the U.S. Geological Survey.

\section{Possible Sources of Selenium to Toll Gate Creek}

Dissolution of efflorescence along the streambanks is insufficient to supply a sustained daily Se load of $250 \mathrm{~g}$ on the basis of the mass-balance calculations presented herein. However, the efflorescent material may indicate that ground water having small Se concentrations is discharging to the stream. The ground water eventually transports the Se to the water of TGC, likely contributing Se along the entire length of the stream, which is consistent with the observed surfacewater-quality data.

The possible supply of Se from shallow ground water in the drainage basin of TGC to the streamwater can be calculated. If a daily load of $250 \mathrm{~g}$ Se in the stream is maintained throughout the year, the annual load would be about $9 \times 10^{4} \mathrm{~g}$. The drainage basin of the stream is about $116 \mathrm{~km}^{2}$ in extent. A rock and unconsolidated sediment layer with an average density of about $2 \mathrm{~g} / \mathrm{cm}$ and volume of $10 \mathrm{~m}$ thickness over an areal extent of $116 \mathrm{~km}^{2}$ with an average Se content of 2 ppm contains $4 \times 10^{9} \mathrm{~g}$ Se. Only a small fraction of this Se would have to dissolve into the water of TGC to supply an annual load of about $9 \times 10^{4} \mathrm{~g}$.

Geologic materials that outcrop and subcrop in the TGC watershed consist of Quaternary colluvial and alluvial deposits overlying the Tertiary to Cretaceous-age Denver Formation. The surficial colluvial and alluvial deposits are composed of unconsolidated gravel, sand, and clay with a dominant mineralogy of quartz and feldspar. The Denver Formation in the study area consists of interbedded sandstones, claystones, and lignite beds of fluvial and volcanic origin and is the likely source of Se to ground water and surface water in the TGC watershed. The Pierre Shale has been identified as a source for Se in water in the Arkansas River basin south of the study area (Zielinski and others, 1995). However, in the study area, the top of the Pierre Shale occurs at least $360 \mathrm{~m}$ below the bottom of the Denver Formation (Suzanne Paschke, U.S. Geological Survey, oral commun., 2006). It is not a likely source for Se occurring in streamwater in TGC.

\section{Remediation of Selenium and Subsequent Monitoring of Trace Elements}

Concentrations of dissolved, oxidized Se in flowing surface water can markedly decrease as the water flows through wetlands (Stillings and Amacher, 2004; Mackowiak and others, 2004). In wetlands, the oxidized Se in the water is chemically reduced and the Se becomes incorporated into the sediment, either in a mineralized form or in organic matter. In this study, there is a possible example of this wetland removal indicated by a downstream decrease in Se load in ETGC (between ETGC-2 and ETGC-1, fig. 6) after the streamwater passes through a wetland and golf course (fig. 9). Furthermore, the anoxic stream mud of sample WTGS/R-2.2B had a Se concentration of $5 \mathrm{ppm}$, which is the second highest concentration of the solid samples and greater than two of the efflorescence samples. The value in this mud is consistent with removal of Se into reducing sediment. Note that these considerations also indicate a possible remedial technique for the removal of Se from the streamwater by incorporating flow through natural or constructed wetlands (Lin and Terry, 2003)

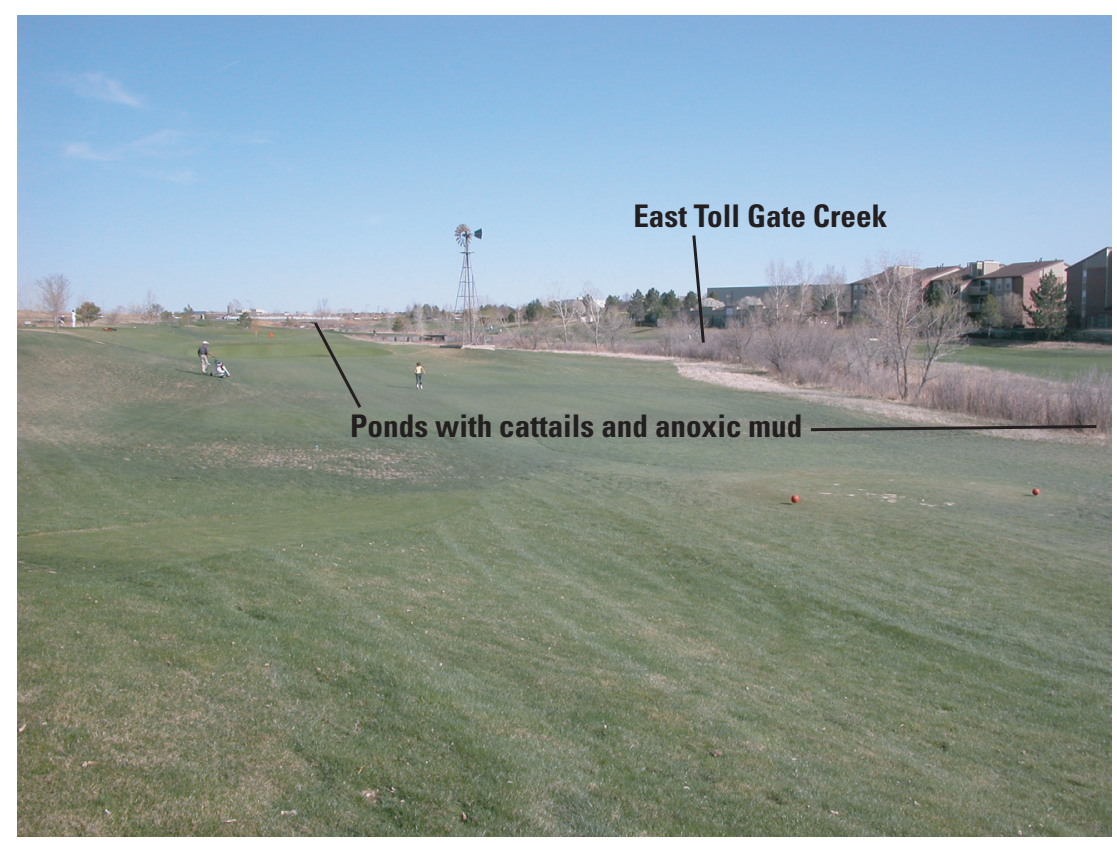

Figure 9. View of wetland and golf course located on East Toll Gate Creek. 


\section{Future Work}

An inventory of the extent of the efflorescent material on the streambanks and its Se content may help understand source areas for the efflorescence and Se where the Se content is elevated. The amount of this material on the streambanks likely changes throughout the year because of dissolution by snowmelt or seasonal storm runoff. Therefore, it would be appropriate to inventory and sample this material several times, for example quarterly, throughout the year.

The origin of the $\mathrm{Se}$ in the white efflorescence deposits on the TGC banks has not been identified. Although it seems likely that the efflorescence results from shallow ground-water seepage toward the stream and consequent discharge onto the surface with evaporation and concentration of Se, there is no direct evidence in this study to support this hypothesis. Therefore, assessment of the Se concentration and the amount of soluble Se in shallow ground water within the drainage area of TGC that might contribute Se to the stream via ground-water discharge would help test the hypothesis that ground water is the source for Se. This assessment could be accomplished by installing a series of monitoring wells. Drilling these wells would allow recovery of rock that can be analyzed for Se content and water-extractable Se content that might help identify which rock layers contribute Se to ground water.

This study concentrated on Se concentrations and load in TGC during low flow. Seasonal sampling would assess how Se concentrations and loads vary over the full range of hydrologic conditions expected in TGC. In addition, more detailed spatial sampling of TGC, its tributaries, and all flowing outfalls may help identify zones where Se load is increasing.

\section{Conclusions}

Streamwater and solid samples were collected in the Toll Gate Creek (TGC) watershed to assess the distribution of selenium (Se) in these materials and evaluate the potential for rocks and solids in the watershed to be sources of Se to the stream. Water samples were collected and discharge measurements were made at as many as 13 sites along East Toll Gate Creek (ETGC), West Toll Gate Creek (WTGC), and TGC during December 2003 and March 2004. Samples were analyzed by inductively coupled plasma mass spectrometry (ICP-MS) and profiles of discharge, Se concentration and Se load were constructed. Twenty-one samples of rock, rock and unconsolidated sediment, stream sediment, and efflorescence were collected along the stream channel of TGC during January and February 2004. Samples were analyzed by energy dispersive $\mathrm{X}$-ray fluorescence (EDXRF), a deionized water (DIW) leaching procedure, a weak nitric-acid leaching procedure, and by $\mathrm{X}$-ray diffraction (XRD). Solutions from the leaching procedures were analyzed by ICP-MS.

Discharge ranged from 2.5 liters per second (L/s) at ETGS-2 in December 2003 to 138 L/s at TGS-1 in March
2004. Except in ETGC, discharge increased moving downstream, and the discharge in WTGC was greater than in ETGC. Downstream increases in discharge indicate that Toll Gate Creek and West Toll Gate Creek gain flow from ground water. Discharge was greater in March 2004 than in December 2003, but both periods were low-flow periods for the TGC watershed. Therefore, the results of this study should not be extrapolated to higher flow periods.

Selenium concentrations in stream samples ranged from 7 to 70 micrograms per liter $(\mu \mathrm{g} / \mathrm{L})$, were elevated in the upstream-most samples collected in WTGC and ETGC, and were greater than the State stream standard of $4.6 \mu \mathrm{g} / \mathrm{L}$ in all stream samples collected along TGC. Average Se concentrations were greater in December $(28 \mu \mathrm{g} / \mathrm{L})$ than in March $2004(14 \mu \mathrm{g} / \mathrm{L})$. The greatest Se concentration $(133 \mu \mathrm{g} / \mathrm{L})$ occurred at the outfall site (OFS-1).

Se loads ranged from 6 grams per day (g/d) at ETGS-1 to $250 \mathrm{~g} / \mathrm{d}$ at TGS-1. Se loads increased along WTGC and TGC, but decreased along ETGC. Se loads generally were greater in December 2003 than in March 2004. Despite elevated concentrations, the outfall sample contained only 18 percent of the load measured at the site directly upstream from where it flowed into TGC (WTGS-0.5). The largest Se-load increases occurred between two sampling locations on West Toll Gate Creek during both sampling periods and between the two sampling locations in Toll Gate Creek during the December 2003 sampling. This result may indicate sources for Se in these locations. However, Se loading along West Toll Gate Creek and Toll Gate Creek generally indicated gradual load increases moving downstream, which is characteristic of a ground-water source for Se. Linear regressions between discharge and Se load indicated significant regressions $(\mathrm{p}<0.0001)$ having large $r^{2}$ values because the load increases (per unit volume of flow increase) into WTGC and TGC (particularly downstream from WTGS-2) generally were constant moving downstream. This pattern is evidence for discharge of ground water along that stream reach that had a relatively constant concentration of Se.

Pearson correlation analysis of water-sample results indicated strong correlations $(\mathrm{p}<0.005)$ between Se and calcium $(\mathrm{Ca})$, and sulfate $\left(\mathrm{SO}_{4}\right)$. A strong, but slightly less significant correlation occurred between Se and sodium (Na). These correlations suggest that the source of Se to the water is a mineral containing $\mathrm{Na}, \mathrm{Ca}$, and $\mathrm{SO}_{4}$ as some of its major constituents.

Rock outcroppings along the stream channel are highly weathered and do not contain elevated concentrations of Se. Selenium was below the detection limit of $1 \mathrm{ppm}$ in 12 of 21 solid samples analyzed. One sample of the efflorescent material had the greatest concentration of Se (25 ppm), and the other efflorescent samples had Se concentrations of 3 and 4 ppm.

Results of deionized water leaching of the efflorescent material indicated that all of the Se dissolved during the leaching procedure, and that some elements in the leachate were concentrated more than sixfold over concentrations in streamwater samples. X-ray diffraction analysis indicated that 
one efflorescent sample was composed of thenardite, gypsum, some halite, and minor silicate minerals likely incorporated into the sample from the underlying outcrop. Calculations indicate that the efflorescent material is not present in sufficient quantity along the banks of TGC to account for the Se load in TGC. However, its presence, and different element ratios in its leachate relative to streamwater indicate that ground-water discharge containing elevated Se concentrations probably produces the efflorescent material.

This report did not identify an unequivocal source for Se in TGC. However, multiple lines of evidence indicate that ground-water discharge supplies Se to TGC: (1) the occurrence of elevated Se concentrations in the stream throughout the watershed and in the headwater regions, upstream from industrial sources; (2) the progressive increase in Se loads moving downstream (particularly the constant increase in load per unit flow downstream from WTGS-2) which indicates a continuous input of Se along the stream reach, rather than input from point sources; (3) the occurrence of efflorescence deposits in several locations along the stream channel that contain elevated concentrations of readily soluble Se, and probably represent ground-water discharge zones; and (4) the occurrence of rock types within the TGC watershed that may contain elevated concentrations of Se (ash layers and lignite deposits). Ground water acquires the Se through water-rock interaction within the aquifers underlying TGC, and shallow ground water containing soluble Se discharges to TGC. This study did not identify which rock formation or mineral was the source of Se to ground water. However, the results of this study indicate that ground water that acquires Se through water-rock interaction within the TGC watershed is the likely source for Se in streamwater in TGC.

\section{References Cited}

Brown and Caldwell and Chadwick Ecological Consultants, 2003, Selenium Stakeholders 2002 Comprehensive Data Analysis Technical Memorandum, prepared for annual Selenium Stakeholders Meeting, April 2003: Brown and Caldwell and Chadwick Ecological Consultants, 55 p. plus appendices.

Cohen, A.C., Jr., 1959, Simplified estimators for the normal distribution when samples are singly censored or truncated: Technometrics, v. 1, p. 217-237.

Colorado Department of Public Health and Environment, 2005, The basic standards and methodologies for surface water (5 CCR 1002-31): Colorado Department of Public Health and Environment, Water Quality Control Commission regulation no. 31, 178 p. accessed September 2006 at http://www.cdphe.state.co.us/regulations/wqccregs/ 100231basicstandards1205and1207.pdf
Connor, J.J. and Shacklette, H.T., and others, 1975, Background geochemistry of some rocks, soils, plants, and vegetables in the conterminous United States, with sections on field studies: U.S. Geological Survey Professional Paper 574-F, 167 p.

Garbarino, J.R. and Hoffman, G.L., 1999, Methods of analysis by the U. S. Geological Survey National Water Quality Laboratory; comparison of a nitric acid in-bottle digestion procedure to other whole-water digestion procedures: U.S. Geological Survey Open-File Report 99-0094, 21p.

Grauch, R.I., Desborough, G.A., Meeker, G.P., Foster, A.L., Tysdal, R.G., Herring, J.R., Lowers, H.A., Ball, B.A., Zielinski, R.A., and Johnson, E.A., 2004, Petrogenesis and mineralogic residence of selected elements in the Meade Peak Phosphatic Shale Member of the Phosphoria Formation, southeast Idaho, in Hein, J.R., ed., Life Cycle of the Phosphoria Formation: From Deposition to the Post-Mining Environment: Amsterdam, Elsevier Press, p. 189-226.

Herring, J.R., 2004, Rock leachate geochemistry of the Meade Peak Phosphatic Shale Member of the Phosphoria Formation, southeast Idaho, in Hein, J.R., ed., Life Cycle of the Phosphoria Formation: From Deposition to the Post-Mining Environment: Amsterdam, Elsevier Press, p. 367-397.

Herring, J.R., and Grauch, R.I., 2004, Lithogeochemistry of the Meade Peak Phosphatic Shale Member of the Phosphoria Formation, southeast Idaho, in Hein, J.R., ed., Life Cycle of the Phosphoria Formation: From Deposition to the Post-Mining Environment: Amsterdam, Elsevier Press, p. 321-366.

Lamothe, P.J., Meier, A.L., and Wilson, S, 2002, The determination of forty four elements in aqueous samples by inductively coupled plasma-mass spectrometry: U.S. Geological Survey Open File Report 02-223H, 13 p. http://pubs.usgs. gov/of/2002/ofr-02-0223/H21\&23OFR99-151_M.pdf

Lin, Zhi-Qing, and Terry, Norman, 2003, Selenium removal by constructed wetlands-quantitative importance of biological volatilization in the treatment of selenium-laden agricultural drainage water: Environmental Science and Technology, v. 37, no. 3, p. 606-615.

Mackowiak, C.L, Amacher, M.A., Hall, J.O., and Herring, J.R., 2004, Uptake of selenium and other contaminant elements into plants and implications for grazing animals in southeast Idaho, in Hein, J.R., ed., Life Cycle of the Phosphoria Formation-From Deposition to the Post-Mining Environment: Amsterdam, Elsevier Press, p. 527-555.

Robson, S.G., 1996, Geohydrology of the shallow aquifers in the Denver metropolitan area, Colorado: U.S. Geological Survey Hydrologic Atlas HA-736, 5 sheets. 
Siems, D.F., 2002, The determination of 30 elements in geological materials by energy-dispersive X-ray fluorescence spectrometry, in Taggart, J.E., Jr., ed., Analytical methods for chemical analysis of geologic and other materials: U.S. Geological Survey Open-File Report 02-223,

$$
\text { p. } \mathrm{U}-1-\mathrm{U}-13 \text {. }
$$

Stillings, L.L., and Amacher, M.A., 2004, Selenium attenuation in a wetland formed from mine drainage in the Phosphoria Formation, southeast Idaho, in Hein, J.R., ed., Life Cycle of the Phosphoria Formation: From Deposition to the Post-Mining Environment: Amsterdam, Elsevier Press, p. 467-482.

Taggart, J.E., Jr., 2002, Analytical methods for chemical analysis of geologic and other materials: U.S. Geological Survey Open-File Report 02-223, 20 p., available on-line at http://pubs.usgs.gov/of/2002/ofr-02-0223/OFR-02-0223.pdf

U.S. Environmental Protection Agency, 2002, List of contaminants and their MCL's: Environmental Protection Agency EPA 816-F-02-013: http://www.epa.gov/safewater/mcl. html\#mcls accessed, June 2006.

U.S. Environmental Protection Agency, 1996, Acid digestion of sediments, sludges, and soils, Method 3050B, Revision 2, December 1996: Washington D.C. http://www.epa.gov/ epaoswer/hazwaste/test/pdfs/3050b.pdf

U.S. Environmental Protection Agency, variously dated, Test Methods for Evaluating Solid Waste, Physical/Chemical Methods, chap. 3, Inorganic Analytes: U.S. Environmental Protection Agency, Manual SW-846. Accessed June 2006 at http://www.epa.gov/epaoswer/hazwaste/test/pdfs/chap3. pdf

Zielinski, R.A., Asher-Bolinder, S., and Meier, A.L., 1995, Uraniferous waters of the Arkansas River valley, Colorado, U.S.A., a function of geology and land use: Applied Geochemistry, v. 10, p. 133-144. 


\section{Appendix A1. Analysis of water samples and calculated, instantaneous selenium loads from sites on Sand Creek and Toll Gate Creek}


[Date in month/day/year, C, degrees Celsius; $\mu \mathrm{S} / \mathrm{cm}$, microsiemen per centimeter; ppm, part per million; ORP, oxidation-reduction potential; mV, millivolt; mg/L, milligram per liter; $\mathrm{L} / \mathrm{s}$, liter per second; $\mu \mathrm{g} / \mathrm{L}$, microgram per liter; g/d, gram per day; $\mathrm{CaCO}_{3}$, calcium carbonate; m, meter; <, less than; Ck, creek; $\mathrm{Se}$, selenium; $\mathrm{Li}$, lithium; $\mathrm{Be}$, beryllium;

$\mathrm{Na}$, sodium; Mg, magnesium; Al, aluminum; Si, silicon; $\mathrm{P}$, phosphorus; $\mathrm{SO}$, sulfate; $\mathrm{K}$, potassium; $\mathrm{Ca}$, calcium; $\mathrm{Sc}$, scandium; Ti, titanium; $\mathrm{V}$, vandium; Cr, chromium; Mn,

manganese; Fe, iron; Co, cobalt; Ni, nickel; Cu, copper; Zn, zinc; Ga, gallium; Ge, germanium; As, arsenic; Rb, rubidium; Sr, strontium; Y, yttrium; Zr, zirconium; Nb, niobium; Mo, molybdenum; Cd, cadmium; Sb, antimony; Cs, cesium; Ba, barium; La, lanthanum; Ce, cerium; W, tungsten; Tl, thallium; Pb, lead; Bi, bismuth; Th, thorium; U, uranium; SCS, Sand Creek stream sample; TGS, Toll Gate Creek stream sample; OFS, outfall sample; WTGS, West Toll Gate Creek stream sample; ETGS, East Toll Gate stream sample]

\begin{tabular}{llll}
\hline Site & Date & Latitude & Longitude \\
\hline Lower Limit of Detection & & Location notes \\
\hline
\end{tabular}

\section{Lower Limit of Detection}

Sand Creek

$\begin{array}{llll}\text { SCS-1 } & \text { 12/16/2003 N } 39.75658 & \text { W } 104.80752 & \text { Sand Ck.,150 m upstream from confluence with Toll }\end{array}$ Gate Ck.

$12 / 17 / 2003$

$3 / 2 / 2004$

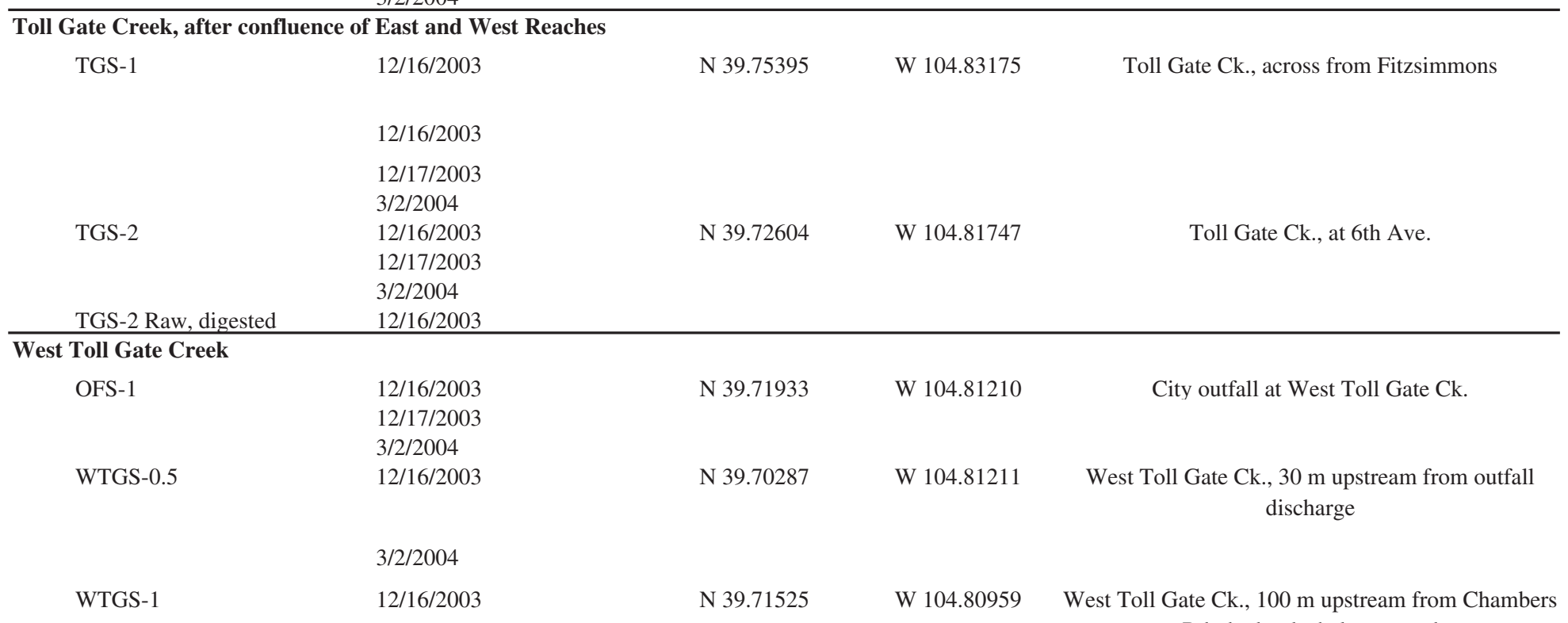

Rd.; bedrock shale exposed 
Table A1. Analysis of water samples and calculated, instantaneous selenium loads from sites on Sand Creek and Toll Gate Creek.-Continued

[Date in month/day/year, C, degrees Celsius; $\mu \mathrm{S} / \mathrm{cm}$, microsiemen per centimeter; ppm, part per million; ORP, oxidation-reduction potential; mV, millivolt; mg/L, milligram per liter; L/s, liter per second; $\mu \mathrm{g} / \mathrm{L}$, microgram per liter; g/d, gram per day; $\mathrm{CaCO}_{3}$, calcium carbonate; m, meter; <, less than; Ck, creek; Se, selenium; Li, lithium; Be, beryllium; $\mathrm{Na}$, sodium; $\mathrm{Mg}$, magnesium; $\mathrm{Al}$, aluminum; $\mathrm{Si}$, silicon; $\mathrm{P}$, phosphorus; $\mathrm{SO}_{4}$, sulfate; $\mathrm{K}$, potassium; $\mathrm{Ca}$, calcium; $\mathrm{Sc}$, scandium; $\mathrm{Ti}$, titanium; $\mathrm{V}$, vandium; $\mathrm{Cr}$, chromium; Mn, manganese; Fe, iron; Co, cobalt; Ni, nickel; $\mathrm{Cu}$, copper; Zn, zinc; Ga, gallium; Ge, germanium; As, arsenic; Rb, rubidium; Sr, strontium; Y, yttrium; Zr, zirconium; $\mathrm{Nb}$, niobium; Mo, molybdenum; Cd, cadmium; Sb, antimony; Cs, cesium; Ba, barium; La, lanthanum; Ce, cerium; W, tungsten; Tl, thallium; $\mathrm{Pb}$, lead; $\mathrm{Bi}$, bismuth; Th, thorium; U, uranium; SCS, Sand Creek stream sample; TGS, Toll Gate Creek stream sample; OFS, outfall sample; WTGS, West Toll Gate Creek stream sample; ETGS, East Toll Gate stream sample]

\begin{tabular}{|c|c|c|c|c|}
\hline Site & Date & Latitude & Longitude & Location notes \\
\hline
\end{tabular}

\section{West Toll Gate Creek}

$12 / 17 / 2003$
$3 / 2 / 2004$

WTGS-2 $12 / 16 / 2003$

$12 / 17 / 2003$
$3 / 2 / 2004$

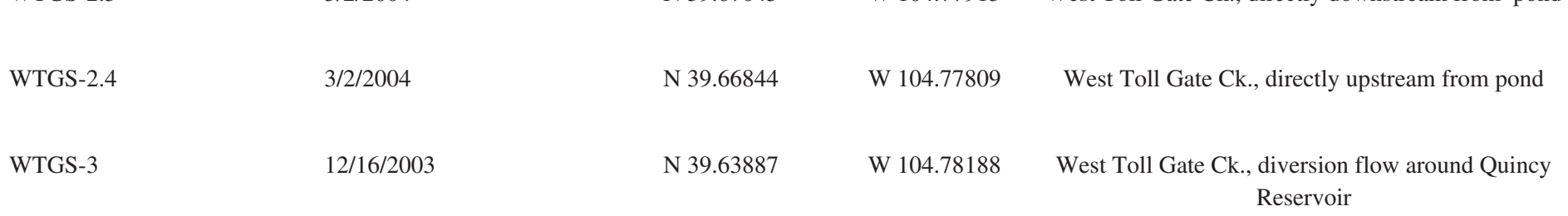

$12 / 17 / 2003$

$3 / 2 / 2004$

WTGS-3.5 3/2/2004 N $39.62608 \quad$ W $104.75158 \quad$ West Toll Gate Ck., 1 km upstream from Quincy

Reservoir; Himalaya Ct. and Chenango St.
Ret.75158

\section{East Toll Gate Creek}

$\begin{array}{ll}\text { ETGS-1 } & 12 / 16 / 2003 \\ & 12 / 17 / 2003 \\ & 3 / 2 / 2004 \\ & 12 / 16 / 2003 \\ & \\ & 12 / 17 / 2003 \\ & 3 / 2 / 2004 \\ & 12 / 16 / 2003\end{array}$

N 39.71751

West Toll Gate Ck., Horse Shoe Park

$$
\text { Reservoir }
$$


Table A1. Analysis of water samples and calculated, instantaneous selenium loads from sites on Sand Creek and Toll Gate Creek.-Continued

[Date in month/day/year, C, degrees Celsius; $\mu \mathrm{S} / \mathrm{cm}$, microsiemen per centimeter; ppm, part per million; ORP, oxidation-reduction potential; mV, millivolt; mg/L, milligram per liter; L/s, liter per second; $\mu \mathrm{g} / \mathrm{L}$, microgram per liter; g/d, gram per day; $\mathrm{CaCO}_{3}$, calcium carbonate; m, meter; <, less than; $\mathrm{Ck}$, creek; Se, selenium; $\mathrm{Li}$, lithium; Be, beryllium; $\mathrm{Na}$, sodium; $\mathrm{Mg}$, magnesium; $\mathrm{Al}$, aluminum; $\mathrm{Si}$, silicon; $\mathrm{P}$, phosphorus; $\mathrm{SO}$, sulfate; $\mathrm{K}$, potassium; $\mathrm{Ca}$, calcium; $\mathrm{Sc}$, scandium; Ti, titanium; $\mathrm{V}$, vandium; $\mathrm{Cr}$, chromium; $\mathrm{Mn}$, manganese; $\mathrm{Fe}$, iron; $\mathrm{Co}$, cobalt; $\mathrm{Ni}$, nickel; Cu, copper; Zn, zinc; Ga, gallium; Ge, germanium; As, arsenic; Rb, rubidium; Sr, strontium; Y, yttrium; Zr, zirconium; Nb, niobium; Mo, molybdenum; Cd, cadmium; Sb, antimony; $\mathrm{Cs}$, cesium; Ba, barium; La, lanthanum; Ce, cerium; W, tungsten; Tl, thallium; Pb, lead; Bi, bismuth; Th, thorium; U, uranium; SCS, Sand Creek stream sample; TGS, Toll Gate Creek stream sample; OFS, outfall sample; WTGS, West Toll Gate Creek stream sample; ETGS, East Toll Gate stream sample]

\begin{tabular}{cccccc}
\hline Site & Date & Comment & Temp., & pH & $\begin{array}{c}\text { Specific } \\
\text { conductance } \\
(\mu \mathrm{S} / \mathrm{cm})\end{array}$ \\
\hline
\end{tabular}

\section{Lower Limit of Detection}

\section{Sand Creek}

SCS-1

$12 / 16 / 2003$

Average of duplicate

$\begin{array}{ll}0 & 6.64\end{array}$

1,623

163

340

\begin{tabular}{|c|c|c|c|c|c|c|c|c|}
\hline & $\begin{array}{l}12 / 17 / 2003 \\
3 / 2 / 2004\end{array}$ & & $\begin{array}{c}0.3 \\
3 \\
\end{array}$ & $\begin{array}{l}7.39 \\
6.02 \\
\end{array}$ & $\begin{array}{l}1,709 \\
1,676 \\
\end{array}$ & $\begin{array}{l}910 \\
889 \\
\end{array}$ & $\begin{array}{c}136 \\
-\end{array}$ & - \\
\hline \multicolumn{9}{|c|}{ Toll Gate Creek, after confluence of East and West Reaches } \\
\hline \multirow[t]{6}{*}{ TGS-1 } & $12 / 16 / 2003$ & $\begin{array}{c}\text { Average of duplicate } \\
\text { pair }\end{array}$ & 0 & 7.08 & 4,045 & 2,230 & 175 & 308 \\
\hline & $12 / 16 / 2003$ & Ice on stream & - & - & - & - & - & - \\
\hline & $\begin{array}{l}12 / 17 / 2003 \\
3 / 2 / 2004\end{array}$ & & $\begin{array}{c}0 \\
45\end{array}$ & $\begin{array}{l}7.57 \\
6.43\end{array}$ & $\begin{array}{l}3,250 \\
2,484\end{array}$ & $\begin{array}{l}1,774 \\
1337\end{array}$ & 155 & - \\
\hline & $12 / 16 / 2003$ & & 3 & 7.29 & 3,205 & 1,751 & 171 & - \\
\hline & $12 / 17 / 2003$ & & 1 & 7.45 & 2,935 & 1,593 & 175 & - \\
\hline & $3 / 2 / 2004$ & & 2 & 6.66 & 2,402 & 1,291 & - & - \\
\hline TGS-2 Raw, digested & $12 / 16 / 2003$ & & & & & & & \\
\hline \multicolumn{9}{|l|}{ West Toll Gate Creek } \\
\hline \multirow[t]{3}{*}{ OFS-1 } & $12 / 16 / 2003$ & & 4 & 7.60 & 4,525 & 2,504 & 188 & - \\
\hline & $12 / 17 / 2003$ & & 7 & 7.82 & 4,254 & 2,351 & 170 & - \\
\hline & $3 / 2 / 2004$ & & 5 & 6.73 & 2,813 & 1,524 & & - \\
\hline \multirow[t]{2}{*}{ WTGS-0.5 } & $12 / 16 / 2003$ & & 3 & 7.70 & 2,993 & 1,626 & 181 & - \\
\hline & $3 / 2 / 2004$ & & 4.5 & 6.87 & 2,372 & 1,275 & & - \\
\hline WTGS-1 & $12 / 16 / 2003$ & & 3 & 7.55 & 2,925 & 1,588 & 207 & - \\
\hline
\end{tabular}


Table A1. Analysis of water samples and calculated, instantaneous selenium loads from sites on Sand Creek and Toll Gate Creek.—Continued

[Date in month/day/year, C, degrees Celsius; $\mu \mathrm{S} / \mathrm{cm}$, microsiemen per centimeter; ppm, part per million; ORP, oxidation-reduction potential; mV, millivolt; mg/L, milligram per liter; L/s, liter per second; $\mu \mathrm{g} / \mathrm{L}$, microgram per liter; g/d, gram per day; $\mathrm{CaCO}_{3}$, calcium carbonate; m, meter; <, less than; Ck, creek; Se, selenium; Li, lithium; Be, beryllium; Na, sodium; Mg, magnesium; $\mathrm{Al}$, aluminum; $\mathrm{Si}$, silicon; $\mathrm{P}$, phosphorus; $\mathrm{SO}_{4}$, sulfate; $\mathrm{K}$, potassium; $\mathrm{Ca}$, calcium; $\mathrm{Sc}$, scandium; Ti, titanium; $\mathrm{V}$, vandium; $\mathrm{Cr}$, chromium; $\mathrm{Mn}$, manganese; $\mathrm{Fe}$, iron; Co, cobalt; $\mathrm{Ni}$, nickel;

$\mathrm{Cu}$, copper; Zn, zinc; Ga, gallium; Ge, germanium; As, arsenic; Rb, rubidium; Sr, strontium; Y, yttrium; Zr, zirconium; Nb, niobium; Mo, molybdenum; Cd, cadmium; Sb, antimony; Cs, cesium; Ba, barium; La, lanthanum; Ce, cerium; W, tungsten; Tl, thallium; Pb, lead; Bi, bismuth; Th, thorium; U, uranium; SCS, Sand Creek stream sample; TGS, Toll Gate Creek stream sample; OFS, outfall sample; WTGS, West Toll Gate Creek stream sample; ETGS, East Toll Gate stream sample]

\begin{tabular}{|c|c|c|c|c|c|c|c|c|}
\hline Site & Date & Comment & $\begin{array}{c}\text { Temp., } \\
\left({ }^{\circ} \mathrm{C}\right)\end{array}$ & pH & $\begin{array}{c}\text { Specific } \\
\text { conductance } \\
(\mu \mathrm{S} / \mathrm{cm})\end{array}$ & $\begin{array}{c}\text { Total } \\
\text { dissolved } \\
\text { solids (ppm) }\end{array}$ & $\begin{array}{l}\text { ORP } \\
(\mathrm{mV})\end{array}$ & $\begin{array}{c}\text { Alkalinity } \\
\text { (mg/L } \\
\left.\mathrm{CaCO}_{3}\right)\end{array}$ \\
\hline
\end{tabular}

Lower Limit of Detection

West Toll Gate Creek

\begin{tabular}{|c|c|c|c|c|c|c|c|c|}
\hline \multirow{5}{*}{ WTGS-2 } & $12 / 17 / 2003$ & & 2 & 7.39 & 2,995 & 1,625 & \multirow[t]{2}{*}{184} & \multirow[t]{2}{*}{-} \\
\hline & $3 / 2 / 2004$ & & 5 & 6.98 & 2,368 & 1,273 & & \\
\hline & $12 / 16 / 2003$ & $\begin{array}{c}\text { Average of duplicate } \\
\text { pair }\end{array}$ & 3 & 6.93 & 3,268 & 1,457 & 134 & 322 \\
\hline & $12 / 17 / 2003$ & & 2 & 7.04 & 3,496 & 1,312 & 171 & - \\
\hline & $3 / 2 / 2004$ & & 5.5 & 6.3 & 2,292 & 1,230 & - & - \\
\hline WTGS-2.3 & $3 / 2 / 2004$ & & 6 & 6.73 & 2,209 & 1,185 & - & - \\
\hline WTGS-2.4 & $3 / 2 / 2004$ & & 11.5 & 7.12 & 2,041 & 1,081 & - & - \\
\hline \multirow[t]{3}{*}{ WTGS-3 } & $12 / 16 / 2003$ & & 2 & 7.43 & 2,693 & 1,785 & 136 & - \\
\hline & $12 / 17 / 2003$ & $\begin{array}{c}\text { Average of duplicate } \\
\text { pair }\end{array}$ & 2 & 7.54 & 2,772 & 1,501 & 175 & - \\
\hline & $3 / 2 / 2004$ & & 4 & 7.24 & 1,579 & 838 & - & - \\
\hline WTGS-3.5 & $3 / 2 / 2004$ & & 6.5 & 7.13 & 2,027 & 1,057 & - & - \\
\hline \multicolumn{9}{|l|}{ Toll Gate Creek } \\
\hline \multirow[t]{4}{*}{ ETGS-1 } & $12 / 16 / 2003$ & & 3 & 7.01 & 2,365 & 1,271 & 112 & 230 \\
\hline & $12 / 17 / 2003$ & & 4 & 7.38 & 2,455 & 1,317 & 144 & - \\
\hline & $3 / 2 / 2004$ & & 7 & 6.96 & 3,584 & 1,958 & & - \\
\hline & $12 / 16 / 2003$ & & 3 & 6.82 & 6,130 & 3,430 & 125 & - \\
\hline \multirow{2}{*}{ ETGS-2 } & $12 / 17 / 2003$ & & 2 & 7.08 & 5,400 & 3,005 & 175 & - \\
\hline & $3 / 2 / 2004$ & & 6.5 & 6.97 & 4,463 & 2,466 & - & - \\
\hline ETGS-2 Raw, digested & $12 / 16 / 2003$ & & & & & & & \\
\hline
\end{tabular}


Table A1. Analysis of water samples and calculated, instantaneous selenium loads from sites on Sand Creek and Toll Gate Creek.-Continued

[Date in month/day/year, C, degrees Celsius; $\mu \mathrm{S} / \mathrm{cm}$, microsiemen per centimeter; ppm, part per million; ORP, oxidation-reduction potential; mV, millivolt; mg/L, milligram per liter; L/s, liter per second; $\mu \mathrm{g} / \mathrm{L}$, microgram per liter; g/d, gram per day; $\mathrm{CaCO}_{3}$, calcium carbonate; m, meter; <, less than; $\mathrm{Ck}$, creek; Se, selenium; Li, lithium; Be, beryllium; $\mathrm{Na}$, sodium; $\mathrm{Mg}$, magnesium; $\mathrm{Al}$, aluminum; Si, silicon; P, phosphorus; $\mathrm{SO}_{4}$, sulfate; $\mathrm{K}$, potassium; Ca, calcium; $\mathrm{Sc}$, scandium; Ti, titanium; $\mathrm{V}$, vandium; $\mathrm{Cr}$, chromium; $\mathrm{Mn}$, manganese; Fe, iron; $\mathrm{Co}$, cobalt; $\mathrm{Ni}$, nickel; $\mathrm{Cu}$, copper $\mathrm{Zn}$, zinc; Ga, gallium; Ge, germanium; As, arsenic; Rb, rubidium; Sr, strontium; Y, yttrium; Zr, zirconium; Nb, niobium; Mo, molybdenum; Cd, cadmium; Sb, antimony; Cs, cesium; Ba, barium; La, lanthanum; Ce, cerium; W, tungsten; Tl, thallium; Pb, lead; Bi, bismuth; Th, thorium; U, uranium; SCS, Sand Creek stream sample; TGS, Toll Gate Creek stream sample; OFS, outfall sample; WTGS, West Toll Gate Creek stream sample; ETGS, East Toll Gate stream sample]

\begin{tabular}{|c|c|c|c|c|c|c|c|c|}
\hline Site & Date & $\begin{array}{c}\text { Discharge } \\
\text { (L/s) }\end{array}$ & $\begin{array}{l}\text { Discharge, } \\
\text { (cubic feet per } \\
\text { second) }\end{array}$ & $\begin{array}{c}\text { Se } \\
(\mu \mathrm{g} / \mathrm{L})\end{array}$ & $\begin{array}{l}\text { Instantaneous } \\
\text { Se load } \\
(\mathbf{g} / \mathbf{d})\end{array}$ & $\begin{array}{l}\text { Instantaneous Se } \\
\text { load (pounds } \\
\text { per year) }\end{array}$ & $\begin{array}{c}\mathbf{L i} \\
(\mu \mathbf{g} / \mathbf{L})\end{array}$ & $\begin{array}{c}\text { Be } \\
(\mu \mathrm{g} / \mathrm{L})\end{array}$ \\
\hline Lower Limit of Detection & & & & $<1$ & & & $<0.9$ & $<0.05$ \\
\hline \multicolumn{9}{|l|}{ Sand Creek } \\
\hline \multirow[t]{2}{*}{ SCS-1 } & $12 / 16 / 2003$ & 19 & 0.68 & 6.8 & 18 & 15 & 62.7 & $<0.06$ \\
\hline & $\begin{array}{l}12 / 17 / 2003 \\
3 / 2 / 2004 \\
\end{array}$ & $\begin{array}{l}- \\
17 \\
\end{array}$ & $\begin{array}{c}- \\
0.60 \\
\end{array}$ & $\begin{array}{l}7.5 \\
4.1 \\
\end{array}$ & $\begin{array}{c}- \\
6.0 \\
\end{array}$ & $\begin{array}{c}- \\
4.8 \\
\end{array}$ & $\begin{array}{l}69.4 \\
103 \\
\end{array}$ & $\begin{array}{c}<0.05 \\
0.2\end{array}$ \\
\hline \multicolumn{9}{|c|}{ Toll Gate Creek, after confluence of East and West Reaches } \\
\hline \multirow[t]{2}{*}{ TGS-1 } & $12 / 16 / 2003$ & 79 & 2.8 & 37 & 250 & 201 & 198 & $<0.05$ \\
\hline & $12 / 16 / 2003$ & - & - & 7.8 & - & - & 35.3 & $<0.05$ \\
\hline TGS-2 Raw, digested & $\begin{array}{l}12 / 17 / 2003 \\
3 / 2 / 2004 \\
12 / 16 / 2003 \\
12 / 17 / 2003 \\
3 / 2 / 2004 \\
12 / 16 / 2003 \\
\end{array}$ & $\begin{array}{c}- \\
138 \\
55 \\
- \\
122\end{array}$ & $\begin{array}{c}- \\
4.9 \\
1.9 \\
- \\
4.3\end{array}$ & $\begin{array}{c}37 \\
15 \\
32 \\
32 \\
13 \\
31.6 \\
\end{array}$ & $\begin{array}{c}- \\
184 \\
150 \\
- \\
138\end{array}$ & $\begin{array}{c}- \\
148 \\
120 \\
- \\
111\end{array}$ & $\begin{array}{l}149 \\
118 \\
144 \\
112 \\
111 \\
148 \\
\end{array}$ & $\begin{array}{l}<0.05 \\
0.06 \\
<0.05 \\
<0.05 \\
<0.05 \\
<0.05\end{array}$ \\
\hline \multicolumn{9}{|l|}{ West Toll Gate Creek } \\
\hline OFS-1 & $\begin{array}{l}12 / 16 / 2003 \\
12 / 17 / 2003 \\
3 / 2 / 2004 \\
12 / 16 / 2003\end{array}$ & $\begin{array}{c}1.22 \\
- \\
6.4 \\
44\end{array}$ & $\begin{array}{c}0.04 \\
- \\
0.2 \\
1.6\end{array}$ & $\begin{array}{c}133 \\
131 \\
51 \\
30.3\end{array}$ & $\begin{array}{c}14 \\
- \\
28 \\
116\end{array}$ & $\begin{array}{c}11 \\
- \\
23 \\
93\end{array}$ & $\begin{array}{l}111 \\
98.1 \\
69.6 \\
116\end{array}$ & $\begin{array}{l}<0.05 \\
<0.05 \\
<0.05 \\
<0.05\end{array}$ \\
\hline & $3 / 2 / 2004$ & 105 & 3.7 & 14 & 128 & 103 & 112 & $<0.05$ \\
\hline WTGS-1 & $12 / 16 / 2003$ & 44 & 1.6 & 32 & 124 & 99 & 107 & $<0.05$ \\
\hline
\end{tabular}


Table A1. Analysis of water samples and calculated, instantaneous selenium loads from sites on Sand Creek and Toll Gate Creek.-Continued

[Date in month/day/year, C, degrees Celsius; $\mu \mathrm{S} / \mathrm{cm}$, microsiemen per centimeter; ppm, part per million; ORP, oxidation-reduction potential; mV, millivolt; mg/L, milligram per liter; L/s, liter per second; $\mu \mathrm{g} / \mathrm{L}$, microgram per liter; g/d, gram per day; $\mathrm{CaCO}_{3}$, calcium carbonate; m, meter; <, less than; Ck, creek; Se, selenium; Li, lithium; Be, beryllium; Na, sodium; Mg, magnesium; $\mathrm{Al}$, aluminum; $\mathrm{Si}$, silicon; $\mathrm{P}$, phosphorus; $\mathrm{SO}_{4}$, sulfate; $\mathrm{K}$, potassium; $\mathrm{Ca}$, calcium; $\mathrm{Sc}$, scandium; $\mathrm{Ti}$, titanium; $\mathrm{V}$, vandium; $\mathrm{Cr}$, chromium; $\mathrm{Mn}$, manganese; $\mathrm{Fe}$, iron; $\mathrm{Co}$, cobalt; $\mathrm{Ni}$, nickel; $\mathrm{Cu}$, copper Zn, zinc; Ga, gallium; Ge, germanium; As, arsenic; Rb, rubidium; Sr, strontium; Y, yttrium; Zr, zirconium; Nb, niobium; Mo, molybdenum; Cd, cadmium; Sb, antimony; Cs, cesium; Ba, barium; La, lanthanum; Ce, cerium; W, tungsten; Tl, thallium; Pb, lead; Bi, bismuth; Th, thorium; U, uranium; SCS, Sand Creek stream sample; TGS, Toll Gate Creek stream sample; OFS, outfall sample; WTGS, West Toll Gate Creek stream sample; ETGS, East Toll Gate stream sample]

\begin{tabular}{|c|c|c|c|c|c|c|c|c|}
\hline Site & Date & $\begin{array}{c}\text { Discharge } \\
\text { (L/s) }\end{array}$ & $\begin{array}{c}\text { Discharge, } \\
\text { (cubic feet } \\
\text { per } \\
\text { second) }\end{array}$ & $\begin{array}{c}\text { Se } \\
(\mu \mathrm{g} / \mathrm{L})\end{array}$ & $\begin{array}{c}\text { Instantaneous } \\
\text { Se } \\
\text { load } \\
(\mathrm{g} / \mathrm{d})\end{array}$ & $\begin{array}{l}\text { Instantaneous } \\
\text { Se load } \\
\text { (pounds } \\
\text { per year) }\end{array}$ & $\begin{array}{c}\mathbf{L i} \\
(\mu \mathrm{g} / \mathrm{L})\end{array}$ & $\begin{array}{c}\text { Be } \\
(\mu \mathrm{g} / \mathrm{L})\end{array}$ \\
\hline Lower Limit of Detection & & & & $<1$ & & & $<0.9$ & $<0.05$ \\
\hline \multicolumn{9}{|l|}{ West Toll Gate Creek } \\
\hline \multirow{5}{*}{ WTGS-2 } & $12 / 17 / 2003$ & - & - & 30 & - & - & 116 & $<0.05$ \\
\hline & $3 / 2 / 2004$ & 104 & 3.7 & 13 & 114 & 92 & 112 & 0.06 \\
\hline & $12 / 16 / 2003$ & 30 & 1.1 & 36 & 91 & 73 & 109 & $<0.05$ \\
\hline & $12 / 17 / 2003$ & - & - & 38 & - & - & 132 & $<0.05$ \\
\hline & $3 / 2 / 2004$ & 56 & 2.0 & 17 & 81 & 65 & 72.6 & 0.06 \\
\hline WTGS-2.3 & $3 / 2 / 2004$ & - & - & 7.4 & - & - & 47.9 & 0.06 \\
\hline WTGS-2.4 & $3 / 2 / 2004$ & - & - & 10.2 & - & - & 56.0 & $<0.05$ \\
\hline \multirow[t]{2}{*}{ WTGS-3 } & $12 / 16 / 2003$ & 11 & 0.4 & 17.9 & 17 & 13 & 75.2 & $<0.05$ \\
\hline & $12 / 17 / 2003$ & - & - & 18.6 & - & - & 79.3 & $<0.05$ \\
\hline & $3 / 2 / 2004$ & 18 & 0.7 & 7.2 & 11 & 9 & 47.1 & 0.09 \\
\hline WTGS-3.5 & $3 / 2 / 2004$ & 6.7 & 0.2 & 12.3 & 7 & 6 & 57.2 & $<0.05$ \\
\hline \multicolumn{9}{|l|}{ East Toll Gate Creek } \\
\hline \multirow[t]{4}{*}{ ETGS-1 } & $12 / 16 / 2003$ & 4.7 & 0.17 & 14.3 & 5.8 & 4.7 & 45.1 & $<0.05$ \\
\hline & $12 / 17 / 2003$ & - & - & 14.3 & - & - & 53.3 & $<0.05$ \\
\hline & $3 / 2 / 2004$ & 7.2 & 0.3 & 13.0 & 8 & 7 & 154 & 0.06 \\
\hline & $12 / 16 / 2003$ & 2.5 & 0.09 & 48.8 & 10 & 8.4 & 257 & $<0.05$ \\
\hline \multirow[b]{3}{*}{ ETGS-2 Raw, digested } & $12 / 17 / 2003$ & - & - & 69.7 & - & - & 274 & $<0.05$ \\
\hline & $3 / 2 / 2004$ & 4.1 & 0.1 & 37.2 & 13 & 11 & 127 & 0.06 \\
\hline & $12 / 16 / 2003$ & & & 49.4 & & & 266 & 0.05 \\
\hline
\end{tabular}


Table A1. Analysis of water samples and calculated, instantaneous selenium loads from sites on Sand Creek and Toll Gate Creek.-Continued

[Date in month/day/year, C, degrees Celsius; $\mu \mathrm{S} / \mathrm{cm}$, microsiemen per centimeter; ppm, part per million; ORP, oxidation-reduction potential; mV, millivolt; mg/L, milligram per liter; L/s, liter per second; $\mu \mathrm{g} / \mathrm{L}$, microgram per liter; g/d, gram per day; $\mathrm{CaCO}_{3}$, calcium carbonate; m, meter; <, less than; Ck, creek; Se, selenium; Li, lithium; Be, beryllium; Na, sodium; Mg, magnesium; $\mathrm{Al}$, aluminum; Si, silicon; P, phosphorus; $\mathrm{SO}_{4}$, sulfate; $\mathrm{K}$, potassium; Ca, calcium; $\mathrm{Sc}$, scandium; Ti, titanium; $\mathrm{V}$, vandium; $\mathrm{Cr}$, chromium; $\mathrm{Mn}$, manganese; Fe, iron; $\mathrm{Co}$, cobalt; $\mathrm{Ni}$, nickel; $\mathrm{Cu}$, copper $\mathrm{Zn}$, zinc; Ga, gallium; Ge, germanium; As, arsenic; Rb, rubidium; Sr, strontium; Y, yttrium; Zr, zirconium; Nb, niobium; Mo, molybdenum; Cd, cadmium; Sb, antimony; Cs, cesium; Ba, barium; La, lanthanum; Ce, cerium; W, tungsten; Tl, thallium; Pb, lead; Bi, bismuth; Th, thorium; U, uranium; SCS, Sand Creek stream sample; TGS, Toll Gate Creek stream sample; OFS, outfall sample; WTGS, West Toll Gate Creek stream sample; ETGS, East Toll Gate stream sample]

\begin{tabular}{|c|c|c|c|c|c|c|c|c|c|}
\hline Site & Date & $\underset{(\mathrm{mg} / \mathrm{L})}{\mathrm{Na}}$ & $\underset{(\mathrm{mg} / \mathrm{L})}{\mathrm{Mg}}$ & $\begin{array}{c}\mathbf{A l} \\
(\mu \mathbf{g} / \mathbf{L})\end{array}$ & $\underset{(\mathrm{mg} / \mathrm{L})}{\mathrm{Si}}$ & $\underset{(\mathrm{mg} / \mathrm{L})}{P}$ & $\begin{array}{c}\mathrm{SO}_{4} \\
(\mathrm{mg} / \mathrm{L})\end{array}$ & $\underset{(m g / L)}{K}$ & $\underset{(\mathrm{mg} / \mathrm{L})}{\mathrm{Ca}}$ \\
\hline Lower & & $<0.5$ & $<0.01$ & $<2$ & $<0.2$ & $<0.01$ & $<2$ & $<0.03$ & $<0.2$ \\
\hline
\end{tabular}

Sand Creek

\begin{tabular}{|c|c|c|c|c|c|c|c|c|c|}
\hline \multicolumn{10}{|l|}{ Sand Creek } \\
\hline \multirow[t]{3}{*}{ SCS-1 } & $12 / 16 / 2003$ & 156 & 28.7 & $<2$ & 12.6 & 0.02 & 302 & 4.9 & 180.0 \\
\hline & $12 / 17 / 2003$ & 146 & 29.2 & $<2$ & 11.8 & 0.01 & 290 & 4.46 & 184 \\
\hline & $3 / 2 / 2004$ & 156 & 27.6 & 8.0 & 8.3 & 0.01 & 323 & 4.55 & 156 \\
\hline \multicolumn{10}{|c|}{ Toll Gate Creek, after confluence of East and West Reaches } \\
\hline \multirow[t]{4}{*}{ TGS-1 } & $12 / 16 / 2003$ & 596 & 65.4 & 2.5 & 9.8 & 0.02 & 832 & 5.5 & 288 \\
\hline & $12 / 16 / 2003$ & 97.5 & 12.2 & 53.6 & 1.8 & 0.04 & 179 & 1.05 & 60.5 \\
\hline & $12 / 17 / 2003$ & 399 & 66.7 & 3.4 & 8.9 & 0.02 & 777 & 5.37 & 288 \\
\hline & $3 / 2 / 2004$ & 313 & 38.2 & 8.6 & 4.7 & 0.07 & 636 & 4.92 & 178 \\
\hline \multirow[t]{3}{*}{ TGS-2 } & $12 / 16 / 2003$ & 414 & 58.7 & 2.9 & 9.0 & 0.03 & 812 & 5.31 & 277 \\
\hline & $12 / 17 / 2003$ & 340 & 65.6 & 3.2 & 8.5 & 0.03 & 750 & 5.21 & 291 \\
\hline & $3 / 2 / 2004$ & 286 & 36.2 & 10 & 4.7 & 0.09 & 572 & 4.84 & 166 \\
\hline TGS-2 Raw, digested & $12 / 16 / 2003$ & 439 & 60 & 158 & 6.9 & 0.2 & 806 & 5.57 & 273 \\
\hline \multicolumn{10}{|l|}{ West Toll Gate Creek } \\
\hline \multirow[t]{3}{*}{ OFS-1 } & $12 / 16 / 2003$ & 700 & 59.4 & 8.5 & 11.4 & 0.04 & 1850 & 9.97 & 440 \\
\hline & $12 / 17 / 2003$ & 597 & 72.5 & 10.1 & 11.7 & 0.08 & 1680 & 8.78 & 477 \\
\hline & $3 / 2 / 2004$ & 370 & 29.9 & 14.7 & 5.5 & 0.07 & 1020 & 3.74 & 221 \\
\hline \multirow[t]{2}{*}{ WTGS-0.5 } & $12 / 16 / 2003$ & 372 & 58.6 & 2.9 & 9.9 & 0.02 & 804 & 4.76 & 275 \\
\hline & $3 / 2 / 2004$ & 283 & 36.0 & 9.3 & 4.6 & 0.10 & 550 & 4.89 & 161 \\
\hline WTGS-1 & $12 / 16 / 2003$ & 370 & 57.5 & 3.4 & 9.6 & 0.03 & 804 & 4.63 & 272 \\
\hline
\end{tabular}


Table A1. Analysis of water samples and calculated, instantaneous selenium loads from sites on Sand Creek and Toll Gate Creek.—Continued

[Date in month/day/year, C, degrees Celsius; $\mu \mathrm{S} / \mathrm{cm}$, microsiemen per centimeter; ppm, part per million; ORP, oxidation-reduction potential; mV, millivolt; mg/L, milligram per liter; L/s, liter per second; $\mu \mathrm{g} / \mathrm{L}$, microgram per liter; g/d, gram per day; $\mathrm{CaCO}_{3}$, calcium carbonate; m, meter; <, less than; Ck, creek; Se, selenium; Li, lithium; Be, beryllium; Na, sodium; Mg, magnesium; Al, aluminum; $\mathrm{Si}$, silicon; $\mathrm{P}$, phosphorus; $\mathrm{SO}$, sulfate; K, potassium; $\mathrm{Ca}$, calcium; $\mathrm{Sc}$, scandium; Ti, titanium; V, vandium; $\mathrm{Cr}$, chromium; $\mathrm{Mn}$, manganese; Fe, iron; $\mathrm{Co}$, cobalt; Ni, nickel; Cu, copper; Zn, zinc; Ga, gallium; Ge, germanium; As, arsenic; Rb, rubidium; Sr, strontium; Y, yttrium; Zr, zirconium; Nb, niobium; Mo, molybdenum; Cd, cadmium; Sb, antimony; Cs, cesium; Ba, barium; La, lanthanum; Ce, cerium; W, tungsten; Tl, thallium; Pb, lead; Bi, bismuth; Th, thorium; U, uranium; SCS, Sand Creek stream sample; TGS, Toll Gate Creek stream sample; OFS, outfall sample; WTGS, West Toll Gate Creek stream sample; ETGS, East Toll Gate stream sample]

\begin{tabular}{|c|c|c|c|c|c|c|c|c|c|}
\hline Site & Date & $\begin{array}{c}\mathrm{Na} \\
(\mathrm{mg} / \mathrm{L})\end{array}$ & $\begin{array}{c}\mathrm{Mg} \\
(\mathrm{mg} / \mathrm{L})\end{array}$ & $\begin{array}{c}\text { Al } \\
(\mu \mathrm{g} / \mathrm{L})\end{array}$ & $\begin{array}{c}\mathrm{Si} \\
(\mathrm{mg} / \mathrm{L})\end{array}$ & $\underset{(m g / L)}{P}$ & $\begin{array}{c}\mathrm{SO}_{4} \\
\text { (mg/L) }\end{array}$ & $\begin{array}{c}\mathrm{K} \\
(\mathrm{mg} / \mathrm{L})\end{array}$ & $\begin{array}{c}\mathrm{Ca} \\
(\mathrm{mg} / \mathrm{L})\end{array}$ \\
\hline Lower Limit of Detection & & $<0.5$ & $<0.01$ & $<2$ & $<0.2$ & $<0.01$ & $<2$ & $<0.03$ & $<0.2$ \\
\hline \multicolumn{10}{|l|}{ West Toll Gate Creek } \\
\hline \multirow{5}{*}{ WTGS-2 } & $12 / 17 / 2003$ & 361 & 78.2 & 5.0 & 9.3 & 0.05 & 789 & 6.19 & 315 \\
\hline & $3 / 2 / 2004$ & 287 & 35.8 & 9.9 & 4.5 & 0.10 & 550 & 5.02 & 158 \\
\hline & $12 / 16 / 2003$ & 391 & 66.5 & 4.9 & 9.6 & 0.07 & 954 & 5.9 & 320 \\
\hline & $12 / 17 / 2003$ & 395 & 94.7 & 3.9 & 11.9 & 0.06 & 904 & 6.73 & 381 \\
\hline & $3 / 2 / 2004$ & 244 & 40.2 & 10.5 & 5.2 & 0.08 & 670 & 4.86 & 205 \\
\hline WTGS-2.3 & $3 / 2 / 2004$ & 199 & 39.7 & 16.7 & 4.4 & 0.03 & 632 & 5.09 & 185 \\
\hline WTGS-2.4 & $3 / 2 / 2004$ & 225 & 39.6 & 10.1 & 5.2 & 0.05 & 641 & 5.18 & 198 \\
\hline \multirow[t]{3}{*}{ WTGS-3 } & $12 / 16 / 2003$ & 307 & 53.1 & $<2$ & 9.4 & 0.08 & 758 & 6.72 & 274 \\
\hline & $12 / 17 / 2003$ & 284 & 73.5 & 7.8 & 10.0 & 0.10 & 728 & 7.9 & 323 \\
\hline & $3 / 2 / 2004$ & 157 & 26.3 & 8.2 & 4.5 & 0.04 & 435 & 5.17 & 142 \\
\hline WTGS-3.5 & $3 / 2 / 2004$ & 169 & 37.1 & 9.2 & 7.2 & 0.05 & 662 & 5.42 & 226 \\
\hline
\end{tabular}

\section{East Toll Gate Creek}

$\begin{array}{ll}\text { ETGS-1 } & 12 / 16 / 2003 \\ & 12 / 17 / 2003 \\ & 3 / 2 / 2004 \\ \text { ETGS-2 } & 12 / 16 / 2003 \\ & 12 / 17 / 2003 \\ & 3 / 2 / 2004 \\ \text { ETGS-2 Raw, digested } & 12 / 16 / 2003\end{array}$

$272 \quad 42.1$


Table A1. Analysis of water samples and calculated, instantaneous selenium loads from sites on Sand Creek and Toll Gate Creek.-Continued

[Date in month/day/year, C, degrees Celsius; $\mu \mathrm{S} / \mathrm{cm}$, microsiemen per centimeter; ppm, part per million; ORP, oxidation-reduction potential; mV, millivolt; mg/L, milligram per liter; L/s, liter per second; $\mu \mathrm{g} / \mathrm{L}$, microgram per liter; g/d, gram per day; $\mathrm{CaCO}_{3}$, calcium carbonate; m, meter; <, less than; Ck, creek; Se, selenium; Li, lithium; Be, beryllium; Na, sodium; Mg, magnesium; $\mathrm{Al}$, aluminum; $\mathrm{Si}$, silicon; $\mathrm{P}$, phosphorus; $\mathrm{SO}$, sulfate; $\mathrm{K}$, potassium; $\mathrm{Ca}$, calcium; $\mathrm{Sc}$, scandium; Ti, titanium; V, vandium; $\mathrm{Cr}$, chromium; $\mathrm{Mn}$, manganese; Fe, iron; $\mathrm{Co}$, cobalt; $\mathrm{Ni}$, nickel; $\mathrm{Cu}$, copper; Zn, zinc; Ga, gallium; Ge, germanium; As, arsenic; Rb, rubidium; Sr, strontium; Y, yttrium; Zr, zirconium; Nb, niobium; Mo, molybdenum; Cd, cadmium; Sb, antimony; Cs, cesium; $\mathrm{Ba}$, barium; La, lanthanum; Ce, cerium; W, tungsten; Tl, thallium; Pb, lead; Bi, bismuth; Th, thorium; U, uranium; SCS, Sand Creek stream sample; TGS, Toll Gate Creek stream sample; OFS, outfall sample; WTGS, West Toll Gate Creek stream sample; ETGS, East Toll Gate stream sample]

\begin{tabular}{|c|c|c|c|c|c|c|c|c|c|}
\hline Site & Date & $\begin{array}{c}\text { Sc } \\
(\mu \mathrm{g} / \mathrm{L})\end{array}$ & $\begin{array}{c}\mathrm{Ti} \\
(\mu \mathrm{g} / \mathrm{L})\end{array}$ & $\underset{(\mu \mathbf{g} / \mathbf{L})}{\mathbf{V}}$ & $\underset{(\mu \mathbf{g} / \mathbf{L})}{\mathbf{C r}}$ & $\begin{array}{c}\mathbf{M n} \\
(\mu \mathbf{g} / \mathbf{L})\end{array}$ & $\begin{array}{c}\mathbf{F e} \\
(\mu \mathrm{g} / \mathbf{L})\end{array}$ & $\begin{array}{c}\text { Co } \\
(\mu \mathbf{g} / \mathbf{L})\end{array}$ & $\underset{(\mu \mathrm{g} / \mathrm{L})}{\mathrm{Ni}}$ \\
\hline Lower Limit of Detection & & $<0.6$ & $<0.5$ & $<0.5$ & $<1$ & $<0.2$ & $<50$ & $<0.02$ & $<0.4$ \\
\hline
\end{tabular}

Sand Creek

\begin{tabular}{|c|c|c|c|c|c|c|c|c|c|}
\hline SCS-1 & $12 / 16 / 2003$ & 3.3 & 4.2 & 3.6 & 8.6 & 81.1 & $<50$ & 0.1 & $<0.4$ \\
\hline & $\begin{array}{l}12 / 17 / 2003 \\
3 / 2 / 2004\end{array}$ & $\begin{array}{l}4.2 \\
2.4 \\
\end{array}$ & $\begin{array}{l}5.4 \\
<0.5 \\
\end{array}$ & $\begin{array}{l}2.6 \\
5.3 \\
\end{array}$ & $\begin{array}{l}6.3 \\
3.9 \\
\end{array}$ & $\begin{array}{l}70.8 \\
217 \\
\end{array}$ & $\begin{array}{l}<50 \\
<50 \\
\end{array}$ & $\begin{array}{l}0.11 \\
0.19 \\
\end{array}$ & $\begin{array}{l}<0.4 \\
<0.4\end{array}$ \\
\hline \multicolumn{10}{|c|}{ Toll Gate Creek, after confluence of East and West Reaches } \\
\hline \multirow[t]{3}{*}{ TGS-1 } & $12 / 16 / 2003$ & 2.8 & 12.4 & 3.8 & 10.2 & 735 & $<50$ & 1.0 & $<0.4$ \\
\hline & $12 / 16 / 2003$ & $<0.6$ & 3.4 & 0.9 & 1.3 & 190 & 83 & 0.34 & $<0.4$ \\
\hline & $\begin{array}{l}12 / 17 / 2003 \\
3 / 2 / 2004\end{array}$ & $\begin{array}{l}3.4 \\
1.3\end{array}$ & $\begin{array}{c}15.1 \\
2.0\end{array}$ & $\begin{array}{l}2.7 \\
5.2\end{array}$ & $\begin{array}{l}5.7 \\
3.8\end{array}$ & $\begin{array}{l}707 \\
491\end{array}$ & $\begin{array}{l}<50 \\
49\end{array}$ & $\begin{array}{l}0.94 \\
1.01\end{array}$ & $\begin{array}{l}<0.4 \\
<0.4\end{array}$ \\
\hline \multirow[t]{3}{*}{ TGS-2 } & $12 / 16 / 2003$ & 2.7 & 12.6 & 2.5 & 5.2 & 741 & $<50$ & 0.91 & $<0.4$ \\
\hline & $12 / 17 / 2003$ & 3.1 & 14.5 & 2.7 & 5.7 & 739 & $<50$ & 0.90 & $<0.4$ \\
\hline & $3 / 2 / 2004$ & 1.4 & 3.8 & 5.6 & 3.5 & 604 & 76 & 1.06 & $<0.4$ \\
\hline TGS-2 Raw, digested & $12 / 16 / 2003$ & 1.5 & 21.5 & 0.9 & $<1$ & 743 & 517 & 1.25 & 4.9 \\
\hline \multicolumn{10}{|l|}{ West Toll Gate Creek } \\
\hline \multirow[t]{3}{*}{ OFS-1 } & $12 / 16 / 2003$ & 3.2 & 26.0 & 3.0 & 7.3 & 75.3 & $<50$ & 0.10 & $<0.4$ \\
\hline & $12 / 17 / 2003$ & 4.0 & 30.2 & 3.0 & 6.8 & 57.6 & $<50$ & 0.04 & $<0.4$ \\
\hline & $3 / 2 / 2004$ & 1.6 & 9.1 & 5.4 & 3.4 & 58.5 & 78 & 0.04 & $<0.4$ \\
\hline \multirow[t]{2}{*}{ WTGS- 0.5} & $12 / 16 / 2003$ & 2.8 & 11.5 & 3.6 & 8.6 & 622 & $<50$ & 0.73 & $<0.4$ \\
\hline & $3 / 2 / 2004$ & 1.4 & 1.4 & 4.8 & 3.3 & 544 & $<50$ & 1.10 & $<0.4$ \\
\hline WTGS-1 & $12 / 16 / 2003$ & 2.7 & 11.8 & 3.3 & 7.2 & 649 & $<50$ & 0.77 & $<0.4$ \\
\hline
\end{tabular}


Table A1. Analysis of water samples and calculated, instantaneous selenium loads from sites on Sand Creek and Toll Gate Creek.-Continued

[Date in month/day/year, C, degrees Celsius; $\mu \mathrm{S} / \mathrm{cm}$, microsiemen per centimeter; ppm, part per million; ORP, oxidation-reduction potential; mV, millivolt; mg/L, milligram per liter; L/s, liter per second; $\mu \mathrm{g} / \mathrm{L}$, microgram per liter; g/d, gram per day; $\mathrm{CaCO}_{3}$, calcium carbonate; m, meter; <, less than; $\mathrm{Ck}$, creek; Se, selenium; Li, lithium; $\mathrm{Be}$, beryllium; $\mathrm{Na}$, sodium; $\mathrm{Mg}$, magnesium; $\mathrm{Al}$, aluminum; $\mathrm{Si}$, silicon; $\mathrm{P}$, phosphorus; $\mathrm{SO}_{4}$, sulfate; $\mathrm{K}$, potassium; $\mathrm{Ca}$, calcium; $\mathrm{Sc}$, scandium; Ti, titanium; $\mathrm{V}$, vandium; $\mathrm{Cr}$, chromium; $\mathrm{Mn}$, manganese; $\mathrm{Fe}$, iron; $\mathrm{Co}$, cobalt; $\mathrm{Ni}$, nickel; $\mathrm{Cu}$, copper Zn, zinc; Ga, gallium; Ge, germanium; As, arsenic; Rb, rubidium; Sr, strontium; Y, yttrium; Zr, zirconium; Nb, niobium; Mo, molybdenum; Cd, cadmium; Sb, antimony; Cs, cesium; Ba, barium; La, lanthanum; Ce, cerium; W, tungsten; Tl, thallium; Pb, lead; Bi, bismuth; Th, thorium; U, uranium; SCS, Sand Creek stream sample; TGS, Toll Gate Creek stream sample; OFS, outfall sample; WTGS, West Toll Gate Creek stream sample; ETGS, East Toll Gate stream sample]

\begin{tabular}{|c|c|c|c|c|c|c|c|c|c|}
\hline Site & Date & $\begin{array}{c}\text { Sc } \\
(\mu \mathrm{g} / \mathrm{L})\end{array}$ & $\begin{array}{c}\mathrm{Ti} \\
(\mu \mathrm{g} / \mathrm{L})\end{array}$ & $\begin{array}{c}\mathbf{V} \\
(\mu \mathbf{g} / \mathbf{L})\end{array}$ & $\begin{array}{c}\mathbf{C r} \\
(\mu \mathrm{g} / \mathrm{L})\end{array}$ & $\begin{array}{c}\text { Mn } \\
(\mu \mathrm{g} / \mathrm{L})\end{array}$ & $\begin{array}{c}\text { Fe } \\
(\mu \mathrm{g} / \mathrm{L})\end{array}$ & $\begin{array}{c}\text { Co } \\
(\mu \mathbf{g} / \mathbf{L})\end{array}$ & $\begin{array}{c}\mathrm{Ni} \\
(\mu \mathrm{g} / \mathrm{L})\end{array}$ \\
\hline Lower Limit of Detection & & $<0.6$ & $<0.5$ & $<0.5$ & $<1$ & $<0.2$ & $<50$ & $<0.02$ & $<0.4$ \\
\hline \multicolumn{10}{|l|}{ West Toll Gate Creek } \\
\hline \multirow{5}{*}{ WTGS-2 } & $12 / 17 / 2003$ & 3.1 & 14.6 & 3.0 & 6.1 & 791 & 51 & 0.88 & $<0.4$ \\
\hline & $3 / 2 / 2004$ & 1.2 & 0.8 & 5.2 & 3.2 & 522 & 200 & 0.93 & $<0.4$ \\
\hline & $12 / 16 / 2003$ & 2.9 & 14.4 & 2.7 & 4.9 & 785 & 50 & 0.75 & $<0.4$ \\
\hline & $12 / 17 / 2003$ & 4.0 & 17.4 & 3.3 & 7.1 & 982 & 71 & 0.92 & $<0.4$ \\
\hline & $3 / 2 / 2004$ & 1.7 & 5.1 & 4.8 & 4.3 & 447 & $<50$ & 0.47 & $<0.4$ \\
\hline WTGS-2.3 & $3 / 2 / 2004$ & 1.6 & 5.2 & 3.4 & 2.9 & 667 & 97 & 0.47 & $<0.4$ \\
\hline WTGS-2.4 & $3 / 2 / 2004$ & 1.6 & 3.5 & 5.5 & 3.6 & 568 & 58 & 0.50 & $<0.4$ \\
\hline \multirow[t]{2}{*}{ WTGS-3 } & $12 / 16 / 2003$ & 2.6 & 10.4 & 3.7 & 7.5 & 41.1 & $<50$ & $<0.02$ & $<0.4$ \\
\hline & $12 / 17 / 2003$ & 3.3 & 14.1 & 3.6 & 6.2 & 60.3 & 48 & 0.0 & $<0.4$ \\
\hline & $3 / 2 / 2004$ & 1.5 & 0.5 & 3.6 & 3.3 & 55.4 & $<50$ & 0.07 & $<0.4$ \\
\hline WTGS-3.5 & $3 / 2 / 2004$ & 2.2 & 2.7 & 5.1 & 4.0 & 939 & 61 & 0.49 & $<0.4$ \\
\hline \multicolumn{10}{|l|}{ East Toll Gate Creek } \\
\hline \multirow[t]{4}{*}{ ETGS-1 } & $12 / 16 / 2003$ & 2.1 & 11.1 & 2.2 & 6.3 & 604 & 63 & 0.75 & $<0.4$ \\
\hline & $12 / 17 / 2003$ & 3.0 & 14.8 & 1.9 & 4.8 & 793 & 64 & 0.89 & $<0.4$ \\
\hline & $3 / 2 / 2004$ & 1.5 & 5.3 & 3.9 & 4.6 & 654 & 55 & 0.78 & 1.1 \\
\hline & $12 / 16 / 2003$ & 1.9 & 19.3 & 2.5 & 6.2 & 2,210 & 77 & 4.01 & $<0.4$ \\
\hline \multirow[b]{3}{*}{ ETGS-2 Raw, digested } & $12 / 17 / 2003$ & 3.1 & 29.4 & 2.9 & 8.0 & 3,130 & 72 & 4.98 & $<0.4$ \\
\hline & $3 / 2 / 2004$ & 1.9 & 15.0 & 4.0 & 5.7 & 2,200 & 113 & 4.64 & $<0.4$ \\
\hline & $12 / 16 / 2003$ & 1.2 & 47.3 & 2.8 & $<1$ & 2,120 & 1,140 & 4.88 & 7.8 \\
\hline
\end{tabular}


Table A1. Analysis of water samples and calculated, instantaneous selenium loads from sites on Sand Creek and Toll Gate Creek.-Continued

[Date in month/day/year, C, degrees Celsius; $\mu \mathrm{S} / \mathrm{cm}$, microsiemen per centimeter; ppm, part per million; ORP, oxidation-reduction potential; mV, millivolt; mg/L, milligram per liter; L/s, liter per second; $\mu \mathrm{g} / \mathrm{L}$, microgram per liter; $\mathrm{g} / \mathrm{d}$, gram per day; $\mathrm{CaCO}$, calcium carbonate; m, meter; <, less than; Ck, creek; Se, selenium; Li, lithium; $\mathrm{Be}$, beryllium; Na, sodium; Mg, magnesium; $\mathrm{Al}$, aluminum; $\mathrm{Si}$, silicon; $\mathrm{P}$, phosphorus; $\mathrm{SO}_{4}$, sulfate; $\mathrm{K}$, potassium; Ca, calcium; $\mathrm{Sc}$, scandium; Ti, titanium; $\mathrm{V}$, vandium; $\mathrm{Cr}$, chromium; $\mathrm{Mn}$, manganese; $\mathrm{Fe}$, iron; $\mathrm{Co}$, cobalt; $\mathrm{Ni}$, nickel; Cu, copper; Zn, zinc; Ga, gallium; Ge, germanium; As, arsenic; Rb, rubidium; Sr, strontium; Y, yttrium; Zr, zirconium; Nb, niobium; Mo, molybdenum; Cd, cadmium; Sb, antimony; Cs, cesium; Ba, barium; La, lanthanum; Ce, cerium; W, tungsten; Tl, thallium; Pb, lead; Bi, bismuth; Th, thorium; U, uranium; SCS, Sand Creek stream sample; TGS, Toll Gate Creek stream sample; OFS, outfall sample; WTGS, West Toll Gate Creek stream sample; ETGS, East Toll Gate stream sample]

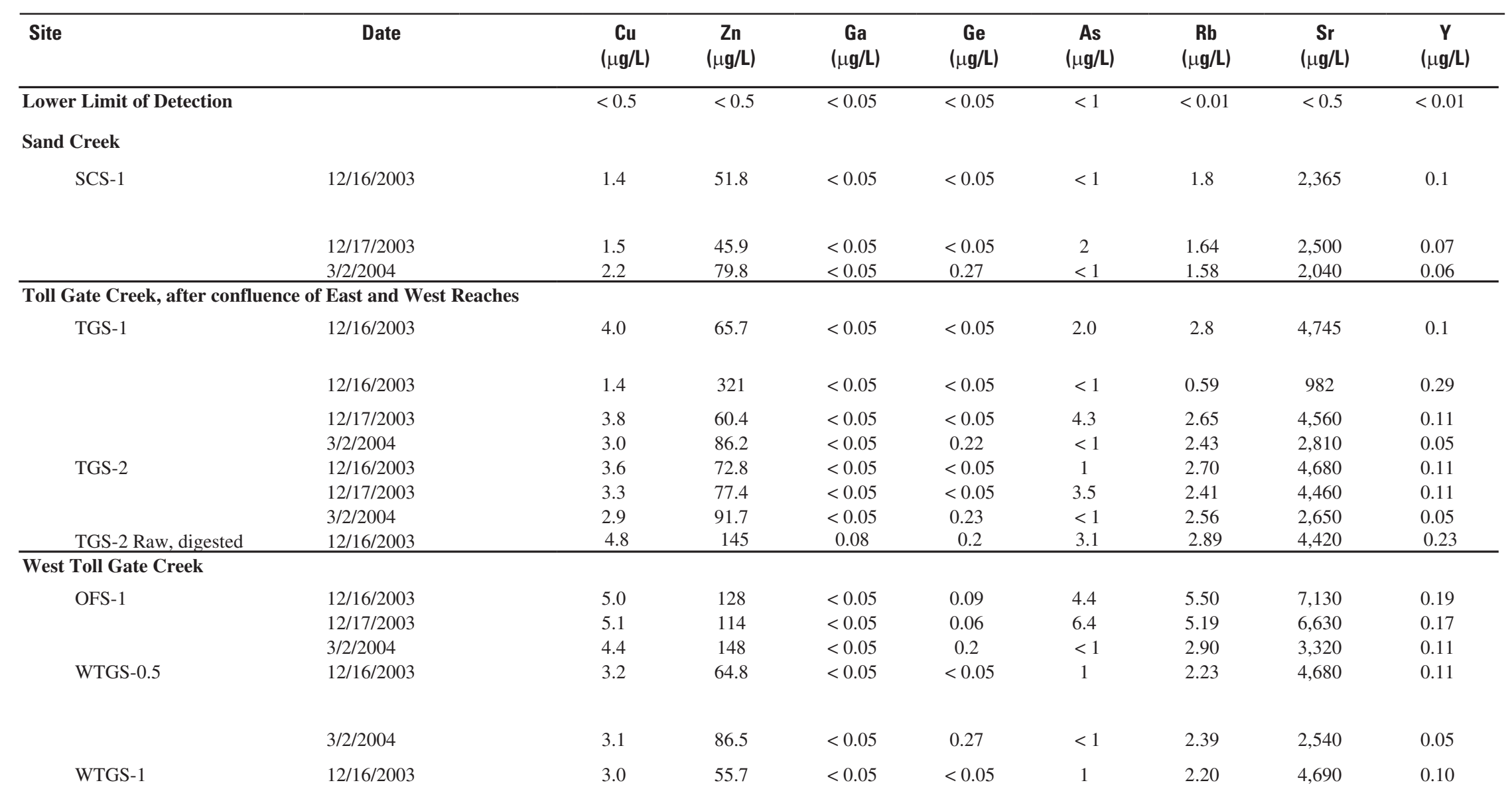


Table A1. Analysis of water samples and calculated, instantaneous selenium loads from sites on Sand Creek and Toll Gate Creek.-Continued

[Date in month/day/year, C, degrees Celsius; $\mu \mathrm{S} / \mathrm{cm}$, microsiemen per centimeter; ppm, part per million; ORP, oxidation-reduction potential; mV, millivolt; mg/L, milligram per liter; L/s, liter per second; $\mu \mathrm{g} / \mathrm{L}$, microgram per liter; g/d, gram per day; $\mathrm{CaCO}_{3}$, calcium carbonate; m, meter; <, less than; Ck, creek; Se, selenium; Li, lithium; Be, beryllium; Na, sodium; Mg, magnesium; $\mathrm{Al}$, aluminum; $\mathrm{Si}$, silicon; $\mathrm{P}$, phosphorus; $\mathrm{SO}_{4}$, sulfate; K, potassium; $\mathrm{Ca}$, calcium; $\mathrm{Sc}$, scandium; Ti, titanium; V, vandium; $\mathrm{Cr}$, chromium; Mn, manganese; Fe, iron; Co, cobalt; $\mathrm{Ni}$, nickel; Cu, copper; Zn, zinc; Ga, gallium; Ge, germanium; As, arsenic; Rb, rubidium; Sr, strontium; Y, yttrium; Zr, zirconium; Nb, niobium; Mo, molybdenum; Cd, cadmium; Sb, antimony; Cs, cesium; Ba, barium; La, lanthanum; Ce, cerium; W, tungsten; Tl, thallium; Pb, lead; Bi, bismuth; Th, thorium; U, uranium; SCS, Sand Creek stream sample; TGS, Toll Gate Creek stream sample; OFS, outfall sample; WTGS, West Toll Gate Creek stream sample; ETGS, East Toll Gate stream sample]

\begin{tabular}{|c|c|c|c|c|c|c|c|c|c|}
\hline Site & Date & $\begin{array}{c}\text { Cu } \\
(\mu \mathrm{g} / \mathrm{L})\end{array}$ & $\begin{array}{c}Z \mathbf{n} \\
(\mu \mathrm{g} / \mathrm{L})\end{array}$ & $\begin{array}{c}\mathbf{G a} \\
(\mu \mathbf{g} / \mathbf{L})\end{array}$ & $\begin{array}{c}\mathbf{G e} \\
(\mu \mathbf{g} / \mathbf{L})\end{array}$ & $\begin{array}{c}\text { As } \\
(\mu \mathrm{g} / \mathrm{L})\end{array}$ & $\begin{array}{c}\mathbf{R b} \\
(\mu \mathbf{g} / \mathbf{L})\end{array}$ & $\begin{array}{c}\text { Sr } \\
(\mu \mathrm{g} / \mathrm{L})\end{array}$ & $\begin{array}{c}\mathbf{Y} \\
(\mu \mathrm{g} / \mathrm{L})\end{array}$ \\
\hline Lower Limit of Detection & & $<0.5$ & $<0.5$ & $<0.05$ & $<0.05$ & $<1$ & $<0.01$ & $<0.5$ & $<0.01$ \\
\hline \multicolumn{10}{|l|}{ West Toll Gate Creek } \\
\hline \multirow{5}{*}{ WTGS-2 } & $12 / 17 / 2003$ & 3.6 & 67.2 & $<0.05$ & $<0.05$ & 3.3 & 2.49 & 4,540 & 0.10 \\
\hline & $3 / 2 / 2004$ & 3.3 & 131 & $<0.05$ & 0.32 & $<1$ & 2.54 & 2,510 & 0.05 \\
\hline & $12 / 16 / 2003$ & 3.1 & 62.2 & $<0.05$ & $<0.05$ & 1.0 & 2.7 & 5,600 & 0.10 \\
\hline & $12 / 17 / 2003$ & 3.2 & 47.9 & $<0.05$ & $<0.05$ & 3.9 & 2.64 & 5,460 & 0.10 \\
\hline & $3 / 2 / 2004$ & 2.3 & 6.6 & $<0.05$ & 0.2 & $<1$ & 1.92 & 3,140 & 0.05 \\
\hline WTGS-2.3 & $3 / 2 / 2004$ & 2.2 & 5.2 & $<0.05$ & 0.32 & $<1$ & 1.35 & 2,890 & 0.05 \\
\hline WTGS-2.4 & $3 / 2 / 2004$ & 1.7 & 4.6 & $<0.05$ & 0.24 & $<1$ & 1.61 & 3,000 & 0.05 \\
\hline \multirow[t]{2}{*}{ WTGS-3 } & $12 / 16 / 2003$ & 2.7 & 57.1 & $<0.05$ & $<0.05$ & $<1$ & 2.11 & 4,420 & 0.10 \\
\hline & $12 / 17 / 2003$ & 2.8 & 67.1 & $<0.05$ & $<0.05$ & 2.5 & 2.3 & 4,410 & 0.1 \\
\hline & $3 / 2 / 2004$ & 2.4 & 5.4 & $<0.05$ & 0.24 & $<1$ & 1.57 & 2,110 & 0.03 \\
\hline WTGS-3.5 & $3 / 2 / 2004$ & 2.7 & 5.8 & $<0.05$ & 0.29 & $<1$ & 1.56 & 3,160 & 0.06 \\
\hline \multicolumn{10}{|l|}{ East Toll Gate Creek } \\
\hline \multirow[t]{4}{*}{ ETGS-1 } & $12 / 16 / 2003$ & 1.9 & 42.3 & $<0.05$ & $<0.05$ & $<1$ & 1.34 & 4,350 & 0.11 \\
\hline & $12 / 17 / 2003$ & 2.2 & 55.3 & $<0.05$ & $<0.05$ & 2 & 1.40 & 4,320 & 0.11 \\
\hline & $3 / 2 / 2004$ & 2.1 & 3.3 & $<0.05$ & 0.21 & $<1$ & 1.39 & 3,930 & 0.10 \\
\hline & $12 / 16 / 2003$ & 6.3 & 86.8 & $<0.05$ & $<0.05$ & 3 & 3.63 & 7,340 & 0.18 \\
\hline \multirow[b]{3}{*}{ ETGS-2 Raw, digested } & $12 / 17 / 2003$ & 4.4 & 46.4 & 0.06 & $<0.05$ & 6.3 & 2.58 & 8,460 & 0.16 \\
\hline & $3 / 2 / 2004$ & 2.6 & 5.6 & $<0.05$ & 0.23 & $<1$ & 1.84 & 5,890 & 0.39 \\
\hline & $12 / 16 / 2003$ & 8.2 & 299 & 0.25 & 0.27 & 11.6 & 4.74 & 6,570 & 0.68 \\
\hline
\end{tabular}


Table A1. Analysis of water samples and calculated, instantaneous selenium loads from sites on Sand Creek and Toll Gate Creek.-Continued

[Date in month/day/year, C, degrees Celsius; $\mu \mathrm{S} / \mathrm{cm}$, microsiemen per centimeter; ppm, part per million; ORP, oxidation-reduction potential; mV, millivolt; mg/L, milligram per liter; L/s, liter per second; $\mu \mathrm{g} / \mathrm{L}$, microgram per liter; g/d, gram per day; $\mathrm{CaCO}_{3}$, calcium carbonate; m, meter; <, less than; Ck, creek; Se, selenium; Li, lithium; Be, beryllium; Na, sodium; Mg, magnesium; $\mathrm{Al}$, aluminum; $\mathrm{Si}$, silicon; $\mathrm{P}$, phosphorus; $\mathrm{SO}_{4}$, sulfate; $\mathrm{K}$, potassium; Ca, calcium; $\mathrm{Sc}$, scandium; $\mathrm{Ti}$, titanium; $\mathrm{V}$, vandium; $\mathrm{Cr}$, chromium; $\mathrm{Mn}$, manganese; $\mathrm{Fe}$, iron; $\mathrm{Co}$, cobalt; $\mathrm{Ni}$, nickel; $\mathrm{Cu}$, copper; Zn, zinc; Ga, gallium; Ge, germanium; As, arsenic; Rb, rubidium; Sr, strontium; Y, yttrium; Zr, zirconium; Nb, niobium; Mo, molybdenum; Cd, cadmium; Sb, antimony; Cs, cesium; Ba, barium; La, lanthanum; Ce, cerium; W, tungsten; Tl, thallium; Pb, lead; Bi, bismuth; Th, thorium; U, uranium; SCS, Sand Creek stream sample; TGS, Toll Gate Creek stream sample; OFS, outfall sample; WTGS, West Toll Gate Creek stream sample; ETGS, East Toll Gate stream sample]

\begin{tabular}{|c|c|c|c|c|c|c|c|c|c|}
\hline Site & Date & $\begin{array}{c}\mathrm{Zr} \\
(\mu \mathrm{g} / \mathrm{L})\end{array}$ & $\begin{array}{c}\mathbf{N b} \\
(\mu \mathbf{g} / \mathbf{L})\end{array}$ & $\begin{array}{c}\text { Mo } \\
(\mu \mathrm{g} / \mathrm{L})\end{array}$ & $\begin{array}{c}\text { Cd } \\
(\mu \mathbf{g} / \mathrm{L})\end{array}$ & $\begin{array}{c}\text { Sb } \\
(\mu \mathbf{g} / \mathbf{L})\end{array}$ & $\underset{(\mu \mathbf{g} / \mathbf{L})}{\text { Cs }}$ & $\begin{array}{c}\text { Ba } \\
(\mu \mathrm{g} / \mathrm{L})\end{array}$ & $\begin{array}{c}\text { La } \\
(\mu \mathrm{g} / \mathrm{L})\end{array}$ \\
\hline Lower Limit of Detection & & $<0.2$ & $<0.2$ & $<2$ & $<0.02$ & $<0.3$ & $<0.02$ & $<0.2$ & $<0.01$ \\
\hline \multicolumn{10}{|l|}{ Sand Creek } \\
\hline \multirow[t]{2}{*}{ SCS-1 } & $12 / 16 / 2003$ & $<0.2$ & 0.2 & 3.2 & $<0.02$ & $<0.3$ & $<0.02$ & 89.7 & 0.0 \\
\hline & $\begin{array}{l}12 / 17 / 2003 \\
3 / 2 / 2004\end{array}$ & $\begin{array}{c}0.2 \\
<0.2 \\
\end{array}$ & $\begin{array}{l}0.33 \\
0.48 \\
\end{array}$ & $\begin{array}{l}2.8 \\
3.0 \\
\end{array}$ & $\begin{array}{l}<0.02 \\
<0.02\end{array}$ & $\begin{array}{l}<0.3 \\
<0.3\end{array}$ & $\begin{array}{l}<0.02 \\
<0.02\end{array}$ & $\begin{array}{l}92.1 \\
72.9 \\
\end{array}$ & $\begin{array}{l}0.01 \\
<0.01 \\
\end{array}$ \\
\hline \multicolumn{10}{|c|}{ Toll Gate Creek, after confluence of East and West Reaches } \\
\hline \multirow[t]{2}{*}{ TGS-1 } & $12 / 16 / 2003$ & 0.2 & 0.2 & 3.3 & 0.1 & 0.5 & $<0.02$ & 65.5 & 0.0 \\
\hline & $12 / 16 / 2003$ & 0.2 & $<0.2$ & $<2$ & 0.16 & $<0.3$ & $<0.02$ & 15.6 & 0.34 \\
\hline 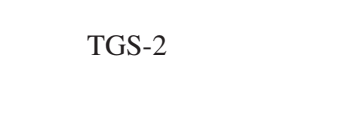 & $\begin{array}{l}12 / 17 / 2003 \\
3 / 2 / 2004 \\
12 / 16 / 2003 \\
12 / 17 / 2003 \\
3 / 2 / 2004 \\
12 / 16 / 2003\end{array}$ & $\begin{array}{l}0.2 \\
<0.2 \\
0.2 \\
<0.2 \\
<0.2 \\
<0.2\end{array}$ & $\begin{array}{l}0.28 \\
0.66 \\
<0.2 \\
0.25 \\
0.65 \\
1.16 \\
\end{array}$ & $\begin{array}{l}2.8 \\
2.7 \\
2.9 \\
2.5 \\
3.2 \\
4.1 \\
\end{array}$ & $\begin{array}{l}0.05 \\
<0.02 \\
0.06 \\
0.04 \\
0.04 \\
0.11 \\
\end{array}$ & $\begin{array}{l}0.30 \\
0.48 \\
0.32 \\
0.50 \\
0.34 \\
0.62 \\
\end{array}$ & $\begin{array}{l}<0.02 \\
<0.02 \\
<0.02 \\
<0.02 \\
<0.02 \\
<0.02\end{array}$ & $\begin{array}{l}56.8 \\
37.1 \\
62.4 \\
56.3 \\
37.5 \\
63.4 \\
\end{array}$ & $\begin{array}{l}0.02 \\
0.01 \\
0.02 \\
0.02 \\
0.02 \\
0.28 \\
\end{array}$ \\
\hline \multicolumn{10}{|l|}{ West Toll Gate Creek } \\
\hline OFS-1 & $\begin{array}{l}12 / 16 / 2003 \\
12 / 17 / 2003 \\
3 / 2 / 2004 \\
12 / 16 / 2003\end{array}$ & $\begin{array}{l}0.2 \\
0.2 \\
<0.2 \\
<0.2\end{array}$ & $\begin{array}{l}<0.2 \\
0.25 \\
0.52 \\
<0.2\end{array}$ & $\begin{array}{l}2.7 \\
2.1 \\
7.4 \\
2.5\end{array}$ & $\begin{array}{l}0.09 \\
0.08 \\
0.06 \\
0.04\end{array}$ & $\begin{array}{l}1.60 \\
2.86 \\
6.94 \\
<0.3\end{array}$ & $\begin{array}{l}0.02 \\
0.03 \\
<0.02 \\
<0.02\end{array}$ & $\begin{array}{l}51.1 \\
39.6 \\
31.1 \\
61.8\end{array}$ & $\begin{array}{l}0.03 \\
0.02 \\
0.03 \\
0.02\end{array}$ \\
\hline WTGS-0.5 & $3 / 2 / 2004$ & $<0.2$ & 0.66 & 2.7 & $<0.02$ & 0.36 & $<0.02$ & 35.6 & 0.02 \\
\hline WTGS-1 & $12 / 16 / 2003$ & $<0.2$ & $<0.2$ & 2.5 & 0.04 & $<0.3$ & $<0.02$ & 62.6 & 0.02 \\
\hline
\end{tabular}


Table A1. Analysis of water samples and calculated, instantaneous selenium loads from sites on Sand Creek and Toll Gate Creek.-Continued

[Date in month/day/year, C, degrees Celsius; $\mu \mathrm{S} / \mathrm{cm}$, microsiemen per centimeter; ppm, part per million; ORP, oxidation-reduction potential; mV, millivolt; mg/L, milligram per liter; L/s, liter per second; $\mu \mathrm{g} / \mathrm{L}$, microgram per liter; g/d, gram per day; $\mathrm{CaCO}_{3}$, calcium carbonate; m, meter; <, less than; Ck, creek; Se, selenium; Li, lithium; Be, beryllium; Na, sodium; Mg, magnesium; $\mathrm{Al}$, aluminum; $\mathrm{Si}$, silicon; $\mathrm{P}$, phosphorus; $\mathrm{SO}_{4}$, sulfate; $\mathrm{K}$, potassium; Ca, calcium; $\mathrm{Sc}$, scandium; Ti, titanium; V, vandium; $\mathrm{Cr}$, chromium; $\mathrm{Mn}$, manganese; $\mathrm{Fe}$, iron; $\mathrm{Co}$, cobalt; $\mathrm{Ni}$, nickel; $\mathrm{Cu}$, copper; Zn, zinc; Ga, gallium; Ge, germanium; As, arsenic; Rb, rubidium; Sr, strontium; Y, yttrium; Zr, zirconium; Nb, niobium; Mo, molybdenum; Cd, cadmium; Sb, antimony; Cs, cesium; Ba, barium; La, lanthanum; Ce, cerium; W, tungsten; Tl, thallium; Pb, lead; Bi, bismuth; Th, thorium; U, uranium; SCS, Sand Creek stream sample; TGS, Toll Gate Creek stream sample; OFS, outfall sample; WTGS, West Toll Gate Creek stream sample; ETGS, East Toll Gate stream sample]

\begin{tabular}{|c|c|c|c|c|c|c|c|c|c|}
\hline Site & Date & $\begin{array}{c}\mathrm{Zr} \\
(\mu \mathrm{g} / \mathrm{L})\end{array}$ & $\begin{array}{c}\mathbf{N b} \\
(\mu \mathbf{g} / \mathbf{L})\end{array}$ & $\begin{array}{c}\text { Mo } \\
(\mu \mathrm{g} / \mathrm{L})\end{array}$ & $\begin{array}{c}\text { Cd } \\
(\mu \mathbf{g} / \mathrm{L})\end{array}$ & $\begin{array}{c}\text { Sb } \\
(\mu \mathbf{g} / \mathbf{L})\end{array}$ & $\begin{array}{c}\text { Cs } \\
(\mu \mathrm{g} / \mathrm{L})\end{array}$ & $\begin{array}{c}\mathbf{B a} \\
(\mu \mathbf{g} / \mathbf{L})\end{array}$ & $\begin{array}{c}\mathbf{L a} \\
(\mu \mathrm{g} / \mathrm{L})\end{array}$ \\
\hline Lower Limit of Detection & & $<0.2$ & $<0.2$ & $<2$ & $<0.02$ & $<0.3$ & $<0.02$ & $<0.2$ & $<0.01$ \\
\hline \multicolumn{10}{|l|}{ West Toll Gate Creek } \\
\hline \multirow{5}{*}{ WTGS-2 } & $12 / 17 / 2003$ & 0.2 & 0.20 & 2.3 & 0.05 & $<0.3$ & $<0.02$ & 56.9 & 0.02 \\
\hline & $3 / 2 / 2004$ & $<0.2$ & 0.45 & 2.7 & 0.03 & 0.38 & $<0.02$ & 35.0 & $<0.01$ \\
\hline & $12 / 16 / 2003$ & 0.2 & $<0.2$ & 2.3 & 0.05 & $<0.3$ & $<0.02$ & 55.8 & 0.02 \\
\hline & $12 / 17 / 2003$ & 0.2 & $<0.2$ & 2.1 & 0.03 & $<0.3$ & $<0.02$ & 56.0 & 0.01 \\
\hline & $3 / 2 / 2004$ & 0.2 & 1.20 & 4.2 & 0.02 & 0.59 & $<0.02$ & 36.7 & $<0.01$ \\
\hline WTGS-2.3 & $3 / 2 / 2004$ & $<0.2$ & 0.81 & 2.4 & $<0.02$ & $<0.3$ & $<0.02$ & 36.2 & 0.02 \\
\hline WTGS-2.4 & $3 / 2 / 2004$ & $<0.2$ & 0.71 & 2.3 & $<0.02$ & 0.38 & $<0.02$ & 37.9 & 0.01 \\
\hline \multirow[t]{2}{*}{ WTGS-3 } & $12 / 16 / 2003$ & $<0.2$ & $<0.2$ & $<2$ & 0.03 & $<0.3$ & $<0.02$ & 56.0 & 0.01 \\
\hline & $12 / 17 / 2003$ & 0.2 & $<0.2$ & 2.0 & 0.02 & $<0.3$ & $<0.02$ & 55.1 & 0.0 \\
\hline & $3 / 2 / 2004$ & 0.2 & 0.85 & 2.8 & $<0.02$ & 0.35 & $<0.02$ & 28.2 & $<0.01$ \\
\hline WTGS-3.5 & $3 / 2 / 2004$ & 0.2 & 1.00 & 2.6 & $<0.02$ & 0.47 & $<0.02$ & 42.1 & $<0.01$ \\
\hline \multicolumn{10}{|l|}{ East Toll Gate Creek } \\
\hline \multirow[t]{4}{*}{ ETGS-1 } & $12 / 16 / 2003$ & $<0.2$ & $<0.2$ & 3.9 & 0.02 & $<0.3$ & $<0.02$ & 78.4 & 0.01 \\
\hline & $12 / 17 / 2003$ & $<0.2$ & $<0.2$ & 3.9 & 0.02 & $<0.3$ & $<0.02$ & 81.5 & 0.01 \\
\hline & $3 / 2 / 2004$ & $<0.2$ & 0.49 & 2.8 & $<0.02$ & $<0.3$ & $<0.02$ & 57.8 & 0.02 \\
\hline & $12 / 16 / 2003$ & 0.3 & $<0.2$ & 3.8 & 0.35 & 0.40 & $<0.02$ & 76.2 & 0.08 \\
\hline \multirow[b]{3}{*}{ ETGS-2 Raw, digested } & $12 / 17 / 2003$ & 0.3 & $<0.2$ & 3.5 & 0.07 & $<0.3$ & $<0.02$ & 55.0 & 0.03 \\
\hline & $3 / 2 / 2004$ & 0.2 & 0.84 & 3.2 & 0.02 & $<0.3$ & $<0.02$ & 40.7 & 0.01 \\
\hline & $12 / 16 / 2003$ & $<0.2$ & 1.61 & 7.3 & 0.48 & 1.23 & 0.13 & 83.3 & 0.96 \\
\hline
\end{tabular}


Table A1. Analysis of water samples and calculated, instantaneous selenium loads from sites on Sand Creek and Toll Gate Creek.—Continued

[Date in month/day/year, C, degrees Celsius; $\mu \mathrm{S} / \mathrm{cm}$, microsiemen per centimeter; ppm, part per million; ORP, oxidation-reduction potential; mV, millivolt; mg/L, milligram per liter; $\mathrm{L} / \mathrm{s}$, liter per second; $\mu \mathrm{g} / \mathrm{L}$, microgram per liter; g/d, gram per day; $\mathrm{CaCO}_{3}$, calcium carbonate; m, meter; <, less than; $\mathrm{Ck}$, creek; $\mathrm{Se}$, selenium; $\mathrm{Li}$, lithium; $\mathrm{Be}$, beryllium; $\mathrm{Na}$, sodium; $\mathrm{Mg}$, magnesium; $\mathrm{Al}$, aluminum; $\mathrm{Si}$, silicon; $\mathrm{P}$, phosphorus; $\mathrm{SO}_{4}$, sulfate; $\mathrm{K}$, potassium; $\mathrm{Ca}$, calcium; $\mathrm{Sc}$, scandium; $\mathrm{Ti}$, titanium; $\mathrm{V}$, vandium; $\mathrm{Cr}$, chromium; $\mathrm{Mn}$, manganese; Fe, iron; Co, cobalt; Ni, nickel; Cu, copper; Zn, zinc; Ga, gallium; Ge, germanium; As, arsenic; Rb, rubidium; Sr, strontium; Y, yttrium; Zr, zirconium; Nb, niobium; Mo, molybdenum; Cd, cadmium; Sb, antimony; Cs, cesium; Ba, barium; La, lanthanum; Ce, cerium; W, tungsten; Tl, thallium; Pb, lead; Bi, bismuth; Th, thorium; U, uranium; SCS, Sand Creek stream sample; TGS, Toll Gate Creek stream sample; OFS, outfall sample; WTGS, West Toll Gate Creek stream sample; ETGS, East Toll Gate stream sample]

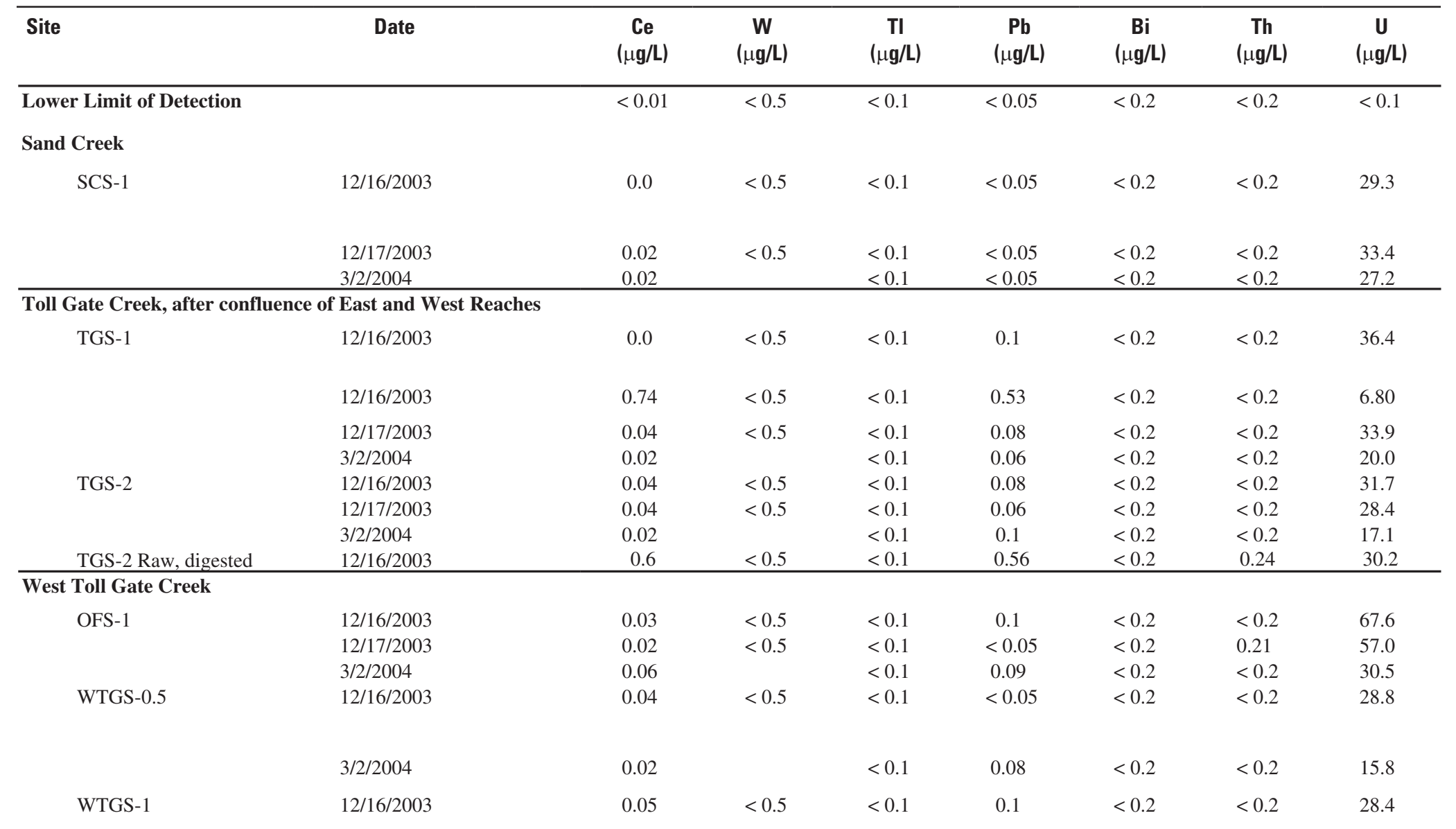


Table A1. Analysis of water samples and calculated, instantaneous selenium loads from sites on Sand Creek and Toll Gate Creek.-Continued

[Date in month/day/year, C, degrees Celsius; $\mu \mathrm{S} / \mathrm{cm}$, microsiemen per centimeter; ppm, part per million; ORP, oxidation-reduction potential; $\mathrm{mV}$, millivolt; mg/L, milligram per liter; $\mathrm{L} / \mathrm{s}$, liter per second; $\mu \mathrm{g} / \mathrm{L}$, microgram per liter; $\mathrm{g} / \mathrm{d}$, gram per day; $\mathrm{CaCO}$, calcium carbonate; m, meter; <, less than; $\mathrm{Ck}$, creek; Se, selenium; Li, lithium; $\mathrm{Be}$, beryllium; $\mathrm{Na}$, sodium; Mg, magnesium; Al, aluminum; $\mathrm{Si}$, silicon; $\mathrm{P}$, phosphorus; $\mathrm{SO}_{4}$, sulfate; $\mathrm{K}$, potassium; $\mathrm{Ca}$, calcium; $\mathrm{Sc}$, scandium; $\mathrm{Ti}$, titanium; $\mathrm{V}$, vandium; $\mathrm{Cr}$, chromium; $\mathrm{Mn}$, manganese; Fe, iron; Co, cobalt; Ni, nickel; Cu, copper; Zn, zinc; Ga, gallium; Ge, germanium; As, arsenic; Rb, rubidium; Sr, strontium; Y, yttrium; Zr, zirconium; Nb, niobium; Mo, molybdenum; Cd, cadmium; Sb, antimony; Cs, cesium; Ba, barium; La, lanthanum; Ce, cerium; W, tungsten; Tl, thallium; Pb, lead; Bi, bismuth; Th, thorium; U, uranium; SCS, Sand Creek stream sample; TGS, Toll Gate Creek stream sample; OFS, outfall sample; WTGS, West Toll Gate Creek stream sample; ETGS, East Toll Gate stream sample]

\begin{tabular}{|c|c|c|c|c|c|c|c|c|}
\hline Site & Date & $\begin{array}{c}\mathrm{Ce} \\
(\mu \mathrm{g} / \mathrm{L})\end{array}$ & $\begin{array}{c}\mathbf{W} \\
(\mu \mathbf{g} / \mathbf{L})\end{array}$ & $\begin{array}{c}\mathrm{TI} \\
(\mu \mathrm{g} / \mathrm{L})\end{array}$ & $\begin{array}{c}\mathbf{P b} \\
(\mu \mathbf{g} / \mathbf{L})\end{array}$ & $\begin{array}{c}\mathbf{B i} \\
(\mu \mathbf{g} / \mathbf{L})\end{array}$ & $\begin{array}{c}\text { Th } \\
(\mu \mathrm{g} / \mathrm{L})\end{array}$ & $\begin{array}{c}\mathbf{U} \\
(\mu \mathbf{g} / \mathbf{L})\end{array}$ \\
\hline Lower Limit of Detection & & $<0.01$ & $<0.5$ & $<0.1$ & $<0.05$ & $<0.2$ & $<0.2$ & $<0.1$ \\
\hline \multicolumn{9}{|l|}{ West Toll Gate Creek } \\
\hline \multirow{5}{*}{ WTGS-2 } & $12 / 17 / 2003$ & 0.05 & $<0.5$ & $<0.1$ & 0.06 & $<0.2$ & $<0.2$ & 26.0 \\
\hline & $3 / 2 / 2004$ & 0.02 & & $<0.1$ & 0.1 & $<0.2$ & $<0.2$ & 15.2 \\
\hline & $12 / 16 / 2003$ & 0.05 & $<0.5$ & $<0.1$ & 0.1 & $<0.2$ & $<0.2$ & 28.9 \\
\hline & $12 / 17 / 2003$ & 0.03 & $<0.5$ & $<0.1$ & 0.06 & $<0.2$ & $<0.2$ & 29.1 \\
\hline & $3 / 2 / 2004$ & 0.02 & & 0.60 & 0.1 & 0.33 & $<0.2$ & 21.6 \\
\hline WTGS-2.3 & $3 / 2 / 2004$ & 0.06 & & $<0.1$ & 0.1 & $<0.2$ & $<0.2$ & 24.3 \\
\hline WTGS-2.4 & $3 / 2 / 2004$ & 0.04 & & $<0.1$ & $<0.05$ & $<0.2$ & $<0.2$ & 21.9 \\
\hline \multirow[t]{2}{*}{ WTGS-3 } & $12 / 16 / 2003$ & 0.02 & $<0.5$ & $<0.1$ & $<0.05$ & $<0.2$ & $<0.2$ & 40.9 \\
\hline & $12 / 17 / 2003$ & 0.1 & $<0.5$ & $<0.1$ & 0.1 & $<0.2$ & $<0.2$ & 38.7 \\
\hline & $3 / 2 / 2004$ & 0.03 & & $<0.1$ & 0.09 & $<0.2$ & $<0.2$ & 25.6 \\
\hline WTGS-3.5 & $3 / 2 / 2004$ & 0.02 & & 0.1 & 0.1 & $<0.2$ & $<0.2$ & 47.2 \\
\hline \multicolumn{9}{|l|}{ East Toll Gate Creek } \\
\hline \multirow[t]{4}{*}{ ETGS-1 } & $12 / 16 / 2003$ & 0.03 & $<0.5$ & $<0.1$ & $<0.05$ & $<0.2$ & $<0.2$ & 19.6 \\
\hline & $12 / 17 / 2003$ & 0.04 & $<0.5$ & $<0.1$ & $<0.05$ & $<0.2$ & $<0.2$ & 17.9 \\
\hline & $3 / 2 / 2004$ & 0.06 & & $<0.1$ & $<0.05$ & $<0.2$ & $<0.2$ & 18.1 \\
\hline & $12 / 16 / 2003$ & 0.18 & $<0.5$ & $<0.1$ & 0.2 & $<0.2$ & $<0.2$ & 49.2 \\
\hline \multirow[b]{3}{*}{ ETGS-2 Raw, digested } & $12 / 17 / 2003$ & 0.07 & $<0.5$ & $<0.1$ & 0.05 & $<0.2$ & $<0.2$ & 52.3 \\
\hline & $3 / 2 / 2004$ & 0.04 & & $<0.1$ & 0.05 & $<0.2$ & $<0.2$ & 39.8 \\
\hline & $12 / 16 / 2003$ & 2.21 & 1.08 & 0.3 & 1.6 & 0.68 & 0.33 & 45.2 \\
\hline
\end{tabular}




\section{Appendix A2. Analytical Quality-Assurance and Quality-Control Data for Toll Gate Creek Water Samples}


Table A2. Analytical quality-assurance and quality-control data for Toll Gate Creek water samples.

[ $\mu \mathrm{g} / \mathrm{L}$, microgram per liter; mg/L, microgram per liter; Dec., December; Mar., March; QC, Quality control; NIST, National Institute of Standards and Technology; \%, percent; <, less than; -, no value; A and B suffix on sample names indicate different replicate samples; Li, lithium; Be, beryllium, $\mathrm{Na}$, sodium; $\mathrm{Mg}$, magnesium; $\mathrm{Al}$, aluminum; $\mathrm{Si}$, silicon; $\mathrm{P}$, phosphorus; $\mathrm{SO}_{4}$, sulfate; $\mathrm{K}$, potassium; $\mathrm{Ca}$, calcium; $\mathrm{Sc}$, scandium; $\mathrm{Ti}$, titanium; $\mathrm{V}$, vanadium; Cr, chromium; Mn, manganese; Fe, iron; Co, cobalt; Ni, nickel; Cu, copper; $\mathrm{Zn}$, zinc; Ga, gallium; Ge, germanium; As, arsenic; Se, selenium; Rb, rubidium; $\mathrm{Sr}$, strontium; Y, yttrium; $\mathrm{Zr}$, zirconium; $\mathrm{Nb}$, niobium; Mo, molybdenum; $\mathrm{Cd}$, cadmium; $\mathrm{Sb}$, antimony; $\mathrm{Cs}$, cesium; $\mathrm{Ba}$, barium; La, lanthanum; Ce, cerium; Tl, thallium; $\mathrm{Pb}$, lead; $\mathrm{Bi}$, bismuth; Th, thorium; $\mathrm{U}$, uranium; \% Difference, the difference between the certified (true) and reported value (or average of reported values) divided by the certified value and expressed as percent; Avg. Abs. Diff., the average of the absolute values of \% Difference for all analytes for one standard reference sample; Grand Avg. Abs. Diff., the average of the absolute values of \% Difference for all analytes and all standard reference samples; Relative \% Diff., the difference between replicate analyses divided by the average of the analyses and expressed as percent; Grand Avg. Precision, the average of Relative \% Diff. for all analytes and all replicate samples]

\begin{tabular}{|c|c|c|c|c|c|c|}
\hline $\begin{array}{l}\text { OC sample, statistic, } \\
\text { and(or) date }\end{array}$ & $\begin{array}{c}\mathbf{L i} \\
(\mu \mathrm{g} / \mathbf{L})\end{array}$ & $\begin{array}{c}\mathrm{Be} \\
(\mu \mathrm{g} / \mathrm{L})\end{array}$ & $\begin{array}{c}\mathrm{Na} \\
(\mathrm{mg} / \mathrm{L})\end{array}$ & $\underset{(\mathrm{mg} / \mathrm{L})}{\mathrm{Mg}}$ & $\begin{array}{c}\text { Al } \\
(\mu \mathrm{g} / \mathrm{L})\end{array}$ & $\begin{array}{c}\mathbf{S i} \\
(\mu \mathbf{g} / \mathbf{L})\end{array}$ \\
\hline \multicolumn{7}{|l|}{ BIAS } \\
\hline $\begin{array}{l}\text { Lower Limit of Detection } \\
18 \text { meg-ohm deionized water wash, all } \\
\text { sample runs }\end{array}$ & $\begin{array}{l}<0.9 \\
<0.1\end{array}$ & $\begin{array}{l}<0.05 \\
<0.05\end{array}$ & $\begin{array}{l}<0.5 \\
<0.5\end{array}$ & $\begin{array}{l}<0.01 \\
<0.01\end{array}$ & $\begin{array}{l}<2 \\
<2\end{array}$ & $\begin{array}{l}<0.2 \\
<0.2\end{array}$ \\
\hline \multicolumn{7}{|l|}{ Dec. 16/17, 2003 QC Samples } \\
\hline NIST-1643d QC standard & 16.1 & 11.8 & 18.6 & 6.89 & 116 & 2.8 \\
\hline Procedural Field Blank 12/16 & $<0.9$ & $<0.05$ & $<0.5$ & $<0.01$ & $<2$ & $<0.2$ \\
\hline Procedural Field Blank 12/17 & $<0.9$ & $<0.05$ & $<0.5$ & $<0.01$ & $<2$ & $<0.2$ \\
\hline NIST-1643d QC standard & 20 & 13.6 & 24 & 9.32 & 152 & 3.1 \\
\hline \multicolumn{7}{|l|}{ QC Summary: } \\
\hline NIST-1643d true & 16.5 & 12.5 & 22.1 & 8 & 128 & 2.7 \\
\hline$\%$ Difference & 9 & 2 & -4 & 1 & 5 & 9 \\
\hline Avg. Abs. Diff. & 5 & & & & & \\
\hline \multicolumn{7}{|l|}{ Mar. 2, 2004 QC Samples } \\
\hline NIST-1643d & 16.9 & 12.8 & 20.7 & 7.58 & 118 & 2.7 \\
\hline $\mathrm{T}-161$ & 18.2 & 14.7 & 42.5 & 1.42 & 62.6 & 6.8 \\
\hline $\mathrm{T}-147$ & 18.4 & 18.1 & 51.3 & 7.71 & 12.9 & 11.2 \\
\hline Procedural Field Blank & 3.8 & 0.1 & $<0.5$ & 0.02 & 7.6 & $<0.2$ \\
\hline NIST-1643d & 16.8 & 12.9 & 21.5 & 7.84 & 123 & 2.8 \\
\hline $\mathrm{T}-161$ & 18.2 & 14.3 & 43.6 & 1.45 & 63.9 & 7 \\
\hline $\mathrm{T}-147$ & 18.5 & 17.7 & 51.4 & 7.74 & 13 & 11.3 \\
\hline
\end{tabular}


[ $\mu \mathrm{g} / \mathrm{L}$, microgram per liter; mg/L, microgram per liter; Dec., December; Mar., March; QC, Quality control; NIST, National Institute of Standards and Technology; \%, percent; <, less than; -, no value; A and B suffix on sample names indicate different replicate samples; Li, lithium; Be, beryllium, $\mathrm{Na}$, sodium; Mg, magnesium; $\mathrm{Al}$, aluminum; $\mathrm{Si}$, silicon; $\mathrm{P}$, phosphorus; $\mathrm{SO}$, sulfate; $\mathrm{K}$, potassium; $\mathrm{Ca}$, calcium; $\mathrm{Sc}$, scandium; Ti, titanium; $\mathrm{V}$, vanadium; $\mathrm{Cr}$, chromium; Mn, manganese; $\mathrm{Fe}$, iron; $\mathrm{Co}$, cobalt; Ni, nickel; Cu, copper; $\mathrm{Zn}$, zinc; Ga, gallium; Ge, germanium; As, arsenic; Se, selenium; Rb, rubidium; Sr, strontium; Y, yttrium; Zr, zirconium; Nb, niobium; Mo, molybdenum; Cd, cadmium; Sb, antimony; Cs, cesium; Ba, barium; La, lanthanum; Ce, cerium; Tl, thallium; $\mathrm{Pb}$, lead; $\mathrm{Bi}$, bismuth; Th, thorium; $\mathrm{U}$, uranium; \% Difference, the difference between the certified (true) and reported value (or average of reported values) divided by the certified value and expressed as percent; Avg. Abs. Diff., the average of the absolute values of \% Difference for all analytes for one standard reference sample; Grand Avg. Abs. Diff., the average of the absolute values of \% Difference for all analytes and all standard reference samples; Relative \% Diff., the difference between replicate analyses divided by the average of the analyses and expressed as percent; Grand Avg. Precision, the average of Relative \% Diff. for all analytes and all replicate samples]

\begin{tabular}{|c|c|c|c|c|c|c|}
\hline $\begin{array}{c}\text { OC sample, statistic, } \\
\text { and(or) date }\end{array}$ & $\underset{(\mu \mathbf{g} / \mathbf{L})}{\mathbf{L i}}$ & $\begin{array}{c}\mathrm{Be} \\
(\mu \mathrm{g} / \mathrm{L})\end{array}$ & $\underset{(\mathrm{mg} / \mathrm{L})}{\mathrm{Na}}$ & $\underset{(\mathrm{mg} / \mathrm{L})}{\mathrm{Mg}}$ & $\begin{array}{c}\text { Al } \\
(\mu \mathrm{g} / \mathrm{L})\end{array}$ & $\underset{(\mu \mathrm{g} / \mathbf{L})}{\mathbf{S i}}$ \\
\hline \multicolumn{7}{|l|}{ BIAS } \\
\hline \multicolumn{7}{|l|}{ QC Summary: } \\
\hline NIST-1643d true & 16.5 & 12.5 & 22.1 & 8.0 & 128 & 2.7 \\
\hline$\%$ Difference & 2 & 2 & -5 & -4 & -6 & 4 \\
\hline Avg. Abs. Diff. & 6 & & & & & \\
\hline T-161 true & 17.8 & 12.9 & 43.0 & 1.51 & 32.4 & 6.92 \\
\hline$\%$ Difference & 2 & 12 & 0 & -4 & 95 & 0 \\
\hline Avg. Abs. Diff. & 8 & & & & & \\
\hline T-147 true & 18.0 & 16.0 & 52.6 & 8.20 & 14.0 & 11.2 \\
\hline$\%$ Difference & 2 & 12 & -2 & -6 & -7 & 0 \\
\hline Avg. Abs. Diff. & 6 & & & & & \\
\hline Grand Avg. Abs. Diff. & 6 & & & & & \\
\hline \multicolumn{7}{|c|}{ PRECISION, FIELD REPLICATES } \\
\hline SCS-1A, 12/6/03 & 62.5 & $<0.05$ & 155 & 28.7 & $<2$ & 12.6 \\
\hline SCS-1B, 12/6/03 & 62.8 & $<0.05$ & 156 & 28.7 & $<2$ & 12.5 \\
\hline Relative \% Diff. & 0.5 & - & 0.6 & 0 & - & 1.0 \\
\hline TGS-1A, 12/6/03 & 200 & $<0.05$ & 596 & 66.5 & 2.5 & 9.8 \\
\hline TGS-1B, 12/6/03 & 195 & $<0.05$ & 596 & 64.2 & 2.5 & 9.8 \\
\hline Relative \% Diff. & 3 & - & 0 & 4 & 0 & 0 \\
\hline WTGS-2A, 12/6/03 & 109 & $<0.05$ & 396 & 66.9 & 4.2 & 9.6 \\
\hline WTGS-2B, 12/6/03 & 108 & $<0.05$ & 385 & 66.1 & 5.6 & 9.6 \\
\hline Relative \% Diff. & 1 & - & 3 & 1 & 29 & 0 \\
\hline Grand Avg. Abs. Diff. & 5 & & & & & \\
\hline
\end{tabular}


Table A2. Analytical quality-assurance and quality-control data for Toll Gate Creek water samples. —Continued

[ $\mu \mathrm{g} / \mathrm{L}$, microgram per liter; mg/L, microgram per liter; Dec., December; Mar., March; QC, Quality control; NIST, National Institute of Standards and Technology; \%, percent; <, less than; -, no value; $\mathrm{A}$ and $\mathrm{B}$ suffix on sample names indicate different replicate samples; Li, lithium; $\mathrm{Be}$, beryllium, Na, sodium; $\mathrm{Mg}$, magnesium; $\mathrm{Al}$, aluminum; $\mathrm{Si}$, silicon; $\mathrm{P}$, phosphorus; $\mathrm{SO}$, sulfate; $\mathrm{K}$, potassium; $\mathrm{Ca}$, calcium; Sc, scandium; Ti, titanium; V, vanadium; Cr, chromium; Mn, manganese; Fe, iron; Co, cobalt; Ni, nickel; Cu, copper; Zn, zinc; Ga, gallium; Ge, germanium; As, arsenic; Se, selenium; $\mathrm{Rb}$, rubidium; Sr, strontium; Y, yttrium; Zr, zirconium; Nb, niobium; Mo, molybdenum; Cd, cadmium; Sb, antimony; $\mathrm{Cs}$, cesium; $\mathrm{Ba}$, barium; La, lanthanum; Ce, cerium; Tl, thallium; Pb, lead; $\mathrm{Bi}$, bismuth; Th, thorium; U, uranium; \% Difference, the difference between the certified (true) and reported value (or average of reported values) divided by the certified value and expressed as percent; Avg. Abs. Diff., the average of the absolute values of $\%$ Difference for all analytes for one standard reference sample; Grand Avg. Abs. Diff., the average of the absolute values of $\%$ Difference for all analytes and all standard reference samples; Relative \% Diff., the difference between replicate analyses divided by the average of the analyses and expressed as percent; Grand Avg. Precision, the average of Relative \% Diff. for all analytes and all replicate samples

\begin{tabular}{|c|c|c|c|c|c|c|c|c|c|}
\hline $\begin{array}{l}\text { OC sample, statistic, } \\
\text { and(or) date }\end{array}$ & $\underset{(m g / L)}{P}$ & $\begin{array}{c}\mathrm{SO}_{4} \\
(\mathrm{mg} / \mathrm{L})\end{array}$ & $\begin{array}{c}\mathrm{K} \\
(\mathrm{mg} / \mathrm{L})\end{array}$ & $\begin{array}{c}\mathrm{Ca} \\
(\mathrm{mg} / \mathrm{L})\end{array}$ & $\begin{array}{c}\text { Sc } \\
(\mu \mathbf{g} / \mathrm{L})\end{array}$ & $\begin{array}{c}\mathrm{Ti} \\
(\mu \mathrm{g} / \mathrm{L})\end{array}$ & $\begin{array}{c}\mathbf{V} \\
(\mu \mathbf{g} / \mathbf{L})\end{array}$ & $\begin{array}{c}\mathrm{Cr} \\
(\mu \mathrm{g} / \mathrm{L})\end{array}$ & $\begin{array}{c}\mathrm{Mn} \\
(\mu \mathrm{g} / \mathrm{L})\end{array}$ \\
\hline \multicolumn{10}{|l|}{ BIAS } \\
\hline $\begin{array}{l}\text { Lower Limit of Detection } \\
18 \text { meg-ohm deionized water wash, all }\end{array}$ & $<0.01$ & $<2$ & $<0.03$ & $<0.2$ & $<0.6$ & $<0.5$ & $<0.5$ & $<1$ & $<0.2$ \\
\hline sample runs & $<0.01$ & $<2$ & $<0.03$ & $<0.2$ & $<0.6$ & $<0.5$ & $<0.5$ & $<1$ & $<0.2$ \\
\hline \multicolumn{10}{|l|}{ Dec. 16/17, 2003 QC Samples } \\
\hline NIST-1643d QC standard & $<0.01$ & $<2$ & 2.19 & 29.6 & 1 & $<0.5$ & 36.5 & 18.9 & 37.5 \\
\hline Procedural Field Blank 12/16 & $<0.01$ & $<2$ & $<0.03$ & $<0.2$ & $<0.6$ & $<0.5$ & $<0.5$ & $<1$ & $<0.2$ \\
\hline Procedural Field Blank 12/17 & $<0.01$ & $<2$ & $<0.03$ & $<0.2$ & $<0.6$ & $<0.5$ & $<0.5$ & $<1$ & $<0.2$ \\
\hline NIST-1643d QC standard & 0.01 & $<2$ & 2.44 & 32.3 & 1.2 & $<0.5$ & 40.4 & 20.8 & 43.2 \\
\hline \multicolumn{10}{|l|}{ QC Summary: } \\
\hline NIST-1643d true & - & - & 2.36 & 31 & - & - & 35.1 & 18.5 & 37.7 \\
\hline $\begin{array}{l}\% \text { Difference } \\
\text { Avg. Abs. Diff. }\end{array}$ & - & - & -2 & 0 & - & - & 10 & 7 & 7 \\
\hline \multicolumn{10}{|l|}{ Mar. 2, 2004 QC Samples } \\
\hline NIST-1643d & 0.01 & $<2$ & 2.14 & 28.4 & 0.9 & $<0.5$ & 34.6 & 17.8 & 37.2 \\
\hline $\mathrm{T}-161$ & $<0.01$ & 5 & 1.18 & 6.63 & 1.8 & 1.5 & 18.1 & 34.2 & 36 \\
\hline $\mathrm{T}-147$ & $<0.01$ & 47 & 3.33 & 38.5 & 3 & $<0.5$ & 15.3 & 11.9 & 16 \\
\hline Procedural Field Blank & $<0.01$ & 13 & 0.03 & $<0.2$ & $<0.6$ & $<0.5$ & $<0.5$ & $<1$ & $<0.2$ \\
\hline NIST-1643d & 0.01 & 3 & 2.26 & 29.9 & 0.8 & $<0.5$ & 35.5 & 18.3 & 37.3 \\
\hline $\mathrm{T}-161$ & $<0.01$ & 6 & 1.22 & 6.83 & 1.9 & 1.3 & 19.1 & 35.3 & 36.7 \\
\hline $\mathrm{T}-147$ & $<0.01$ & 48 & 3.37 & 38.8 & 2.9 & $<0.5$ & 15.6 & 12.2 & 15.9 \\
\hline
\end{tabular}


[ $\mu \mathrm{g} / \mathrm{L}$, microgram per liter; mg/L, microgram per liter; Dec., December; Mar., March; QC, Quality control; NIST, National Institute of Standards and Technology; \%, percent; <, less than; -, no value; $\mathrm{A}$ and $\mathrm{B}$ suffix on sample names indicate different replicate samples; $\mathrm{Li}$, lithium; $\mathrm{Be}$, beryllium, $\mathrm{Na}$, sodium; $\mathrm{Mg}$, magnesium; $\mathrm{Al}$, aluminum; $\mathrm{Si}$, silicon; $\mathrm{P}$, phosphorus; $\mathrm{SO}$, sulfate; $\mathrm{K}$, potassium; $\mathrm{Ca}$, calcium; Sc, scandium; Ti, titanium; V, vanadium; Cr, chromium; Mn, manganese; Fe, iron; Co, cobalt; Ni, nickel; Cu, copper; Zn, zinc; Ga, gallium; Ge, germanium; As, arsenic; Se, selenium; $\mathrm{Rb}$, rubidium; Sr, strontium; Y, yttrium; Zr, zirconium; Nb, niobium; Mo, molybdenum; Cd, cadmium; Sb, antimony; Cs, cesium; Ba, barium; La, lanthanum; Ce, cerium; Tl, thallium; Pb, lead; Bi, bismuth; Th, thorium; U, uranium; \% Difference, the difference between the certified (true) and reported value (or average of reported values) divided by the certified value and expressed as percent; Avg. Abs. Diff., the average of the absolute values of \% Difference for all analytes for one standard reference sample; Grand Avg. Abs. Diff., the average of the absolute values of \% Difference for all analytes and all standard reference samples; Relative \% Diff., the difference between replicate analyses divided by the average of the analyses and expressed as percent; Grand Avg. Precision, the average of Relative \% Diff. for all analytes and all replicate samples]

\begin{tabular}{|c|c|c|c|c|c|c|c|c|c|}
\hline $\begin{array}{l}\text { OC sample, statistic, } \\
\text { and(or) date }\end{array}$ & $\begin{array}{c}P \\
(\mathrm{mg} / \mathrm{L})\end{array}$ & $\begin{array}{c}\mathrm{SO}_{4} \\
(\mathrm{mg} / \mathrm{L})\end{array}$ & $\begin{array}{c}\mathrm{K} \\
(\mathrm{mg} / \mathrm{L})\end{array}$ & $\begin{array}{c}\mathrm{Ca} \\
(\mathrm{mg} / \mathrm{L})\end{array}$ & $\begin{array}{c}\text { Sc } \\
(\mu \mathrm{g} / \mathrm{L})\end{array}$ & $\begin{array}{c}\mathrm{Ti} \\
(\mu \mathrm{g} / \mathrm{L})\end{array}$ & $\begin{array}{c}\mathbf{V} \\
(\mu \mathrm{g} / \mathrm{L})\end{array}$ & $\begin{array}{c}\mathrm{Cr} \\
(\mu \mathrm{g} / \mathrm{L})\end{array}$ & $\begin{array}{c}\text { Mn } \\
(\mu g / L)\end{array}$ \\
\hline \multicolumn{10}{|l|}{ BIAS } \\
\hline \multicolumn{10}{|l|}{ QC Summary: } \\
\hline NIST-1643d true & - & - & 2.36 & 3.1 & - & - & 35.1 & 18.5 & 37.7 \\
\hline$\%$ Difference & - & - & -7 & -6 & - & - & 0 & -2 & -1 \\
\hline \multicolumn{10}{|l|}{ Avg. Abs. Diff. } \\
\hline $\mathrm{T}-161$ true & - & - & 1.26 & 7.17 & - & - & 18.4 & 34.6 & 37.4 \\
\hline$\%$ Difference & - & - & -5 & -6 & - & - & 1 & 0 & -3 \\
\hline \multicolumn{10}{|l|}{ Avg. Abs. Diff. } \\
\hline $\mathrm{T}-147$ true & - & - & 3.52 & 41.1 & - & - & 15.2 & 12.8 & 17.2 \\
\hline$\%$ Difference & - & - & -5 & -6 & - & - & & -6 & -7 \\
\hline \multicolumn{10}{|l|}{ Avg. Abs. Diff. } \\
\hline \multicolumn{10}{|l|}{ Grand Avg. Abs. Diff. } \\
\hline \multicolumn{10}{|c|}{ PRECISION, FIELD REPLICATES } \\
\hline SCS-1A, 12/6/03 & 0.02 & 301 & 4.9 & 180 & 3.3 & 4.1 & 3.7 & 9.2 & 80.8 \\
\hline SCS-1B, 12/6/03 & 0.01 & 302 & 4.81 & 180 & 3.3 & 4.2 & 3.4 & 8 & 81.4 \\
\hline Relative \% Diff. & 67.0 & 0.3 & 2 & 0 & 0 & 2 & 8 & 14 & 0.7 \\
\hline TGS-1A, 12/6/03 & 0.02 & 822 & 5.47 & 288 & 2.8 & 12 & 3.6 & 9.7 & 738 \\
\hline TGS-1B, 12/6/03 & 0.02 & 842 & 5.47 & 287 & 2.8 & 12.7 & 3.9 & 10.7 & 732 \\
\hline Relative \% Diff. & 0 & 2 & 0 & 0.3 & 0 & 6 & 8 & 10 & 0.8 \\
\hline WTGS-2A, 12/6/03 & 0.07 & 963 & 5.94 & 321 & 2.8 & 13.8 & 2.5 & 4.1 & 783 \\
\hline WTGS-2B, 12/6/03 & 0.07 & 944 & 5.87 & 318 & 2.9 & 15 & 2.9 & 5.7 & 786 \\
\hline Relative \% Diff. & 0 & 2 & 1 & 0.9 & 4 & 8 & 15 & 33 & 0.4 \\
\hline
\end{tabular}

Grand Avg. Abs. Diff. 
Table A2. Analytical quality-assurance and quality-control data for Toll Gate Creek water samples. —Continued

[ $\mu \mathrm{g} / \mathrm{L}$, microgram per liter; mg/L, microgram per liter; Dec., December; Mar., March; QC, Quality control; NIST, National Institute of Standards and Technology; \%, percent; <, less than; -, no value; $\mathrm{A}$ and $\mathrm{B}$ suffix on sample names indicate different replicate samples; $\mathrm{Li}$, lithium; $\mathrm{Be}$, beryllium, $\mathrm{Na}$, sodium; $\mathrm{Mg}$, magnesium; $\mathrm{Al}$, aluminum; $\mathrm{Si}$, silicon; $\mathrm{P}$, phosphorus; $\mathrm{SO}$, sulfate; $\mathrm{K}$, potassium; $\mathrm{Ca}$, calcium; Sc, scandium; Ti, titanium; V, vanadium; Cr, chromium; Mn, manganese; Fe, iron; Co, cobalt; Ni, nickel; Cu, copper; Zn, zinc; Ga, gallium; Ge, germanium; As, arsenic; Se, selenium; Rb, rubidium; Sr, strontium; Y, yttrium; Zr, zirconium; Nb, niobium; Mo, molybdenum; Cd, cadmium; Sb, antimony; Cs, cesium; Ba, barium; La, lanthanum; Ce, cerium; Tl, thallium; Pb, lead; Bi, bismuth; Th, thorium; U, uranium; \% Difference, the difference between the certified (true) and reported value (or average of reported values) divided by the certified value and expressed as percent; Avg. Abs. Diff., the average of the absolute values of \% Difference for all analytes for one standard reference sample; Grand Avg. Abs. Diff., the average of the absolute values of \% Difference for all analytes and all standard reference samples; Relative \% Diff., the difference between replicate analyses divided by the average of the analyses and expressed as percent; Grand Avg. Precision, the average of Relative \% Diff. for all analytes and all replicate samples

\begin{tabular}{|c|c|c|c|c|c|c|c|c|c|}
\hline $\begin{array}{c}\text { OC sample, statistic, } \\
\text { and(or) date }\end{array}$ & $\begin{array}{c}\text { Fe } \\
(\mu \mathrm{g} / \mathrm{L})\end{array}$ & $\begin{array}{c}\text { Co } \\
(\mu \mathrm{g} / \mathrm{L})\end{array}$ & $\begin{array}{c}\mathbf{N i} \\
(\mu \mathrm{g} / \mathrm{L})\end{array}$ & $\begin{array}{c}\text { Cu } \\
(\mu \mathrm{g} / \mathrm{L})\end{array}$ & $\begin{array}{c}\mathrm{Zn} \\
(\mu \mathrm{g} / \mathrm{L})\end{array}$ & $\begin{array}{c}\text { Ga } \\
(\mu \mathrm{g} / \mathrm{L})\end{array}$ & $\begin{array}{c}\mathbf{G e} \\
(\mu \mathbf{g} / \mathbf{L})\end{array}$ & $\begin{array}{c}\text { As } \\
(\mu \mathrm{g} / \mathrm{L})\end{array}$ & $\begin{array}{c}\text { Se } \\
(\mu \mathrm{g} / \mathrm{L})\end{array}$ \\
\hline \multicolumn{10}{|l|}{ BIAS } \\
\hline $\begin{array}{l}\text { Lower Limit of Detection } \\
18 \text { meg-ohm deionized water wash, all }\end{array}$ & $<50$ & $<0.02$ & $<0.4$ & $<0.5$ & $<0.5$ & $<0.05$ & $<0.05$ & $<1$ & $<1$ \\
\hline sample runs & $<50$ & $<0.02$ & $<0.4$ & $<0.5$ & $<0.5$ & $<0.05$ & $<0.05$ & $<1$ & $<1$ \\
\hline \multicolumn{10}{|l|}{ Dec. 16/17, 2003 QC Samples } \\
\hline NIST-1643d QC standard & 109 & 25.1 & 57 & 20.1 & 68.9 & $<0.05$ & 0.1 & 52.3 & 11 \\
\hline Procedural Field Blank 12/16 & $<50$ & $<0.02$ & $<0.4$ & $<0.5$ & 49.8 & $<0.05$ & $<0.05$ & $<1$ & $<1$ \\
\hline Procedural Field Blank 12/17 & $<50$ & $<0.02$ & $<0.4$ & $<0.5$ & 62.1 & $<0.05$ & $<0.05$ & $<1$ & $<1$ \\
\hline NIST-1643d QC standard & 122 & 27.3 & 61.1 & 21.3 & 76 & $<0.05$ & 0.2 & 57.9 & 12 \\
\hline \multicolumn{10}{|l|}{ QC Summary: } \\
\hline NIST-1643d true & 91.2 & 25 & 58.1 & 20.5 & 72.5 & - & - & 56 & 11.4 \\
\hline$\%$ Difference & 27 & 5 & 2 & 1 & 0 & - & - & -2 & 1 \\
\hline \multicolumn{10}{|l|}{ Avg. Abs. Diff. } \\
\hline \multicolumn{10}{|l|}{ Mar. 2, 2004 QC Samples } \\
\hline NIST-1643d & 107 & 24.6 & 55 & 19.7 & 66.8 & $<0.05$ & 0.1 & 48.7 & 10.3 \\
\hline $\mathrm{T}-161$ & 57 & 12.3 & 29.2 & 21.9 & 44.3 & $<0.05$ & $<0.05$ & 24.5 & 10.2 \\
\hline $\mathrm{T}-147$ & $<50$ & 0.09 & 12.4 & 11.4 & 14.2 & $<0.05$ & 0.09 & 2 & 11.1 \\
\hline Procedural Field Blank & $<50$ & $<0.02$ & $<0.4$ & 0.57 & 3.8 & $<0.05$ & 0.2 & $<1$ & $<1$ \\
\hline NIST-1643d & 111 & 24.7 & 56.5 & 20.3 & 70.2 & $<0.05$ & 0.1 & 48.3 & 10.7 \\
\hline $\mathrm{T}-161$ & 62 & 12.3 & 28.9 & 22.2 & 45.8 & $<0.05$ & $<0.05$ & 24.9 & 10.9 \\
\hline $\mathrm{T}-147$ & $<50$ & 0.08 & 12.4 & 11.7 & 14.7 & $<0.05$ & 0.1 & 2 & 11.4 \\
\hline
\end{tabular}


[ $\mu \mathrm{g} / \mathrm{L}$, microgram per liter; mg/L, microgram per liter; Dec., December; Mar., March; QC, Quality control; NIST, National Institute of Standards and Technology; \%, percent; <, less than; -, no value; $\mathrm{A}$ and $\mathrm{B}$ suffix on sample names indicate different replicate samples; $\mathrm{Li}$, lithium; Be, beryllium, $\mathrm{Na}$, sodium; $\mathrm{Mg}$, magnesium; $\mathrm{Al}$, aluminum; $\mathrm{Si}$, silicon; $\mathrm{P}$, phosphorus; $\mathrm{SO}$, sulfate; $\mathrm{K}$, potassium; Ca, calcium; Sc, scandium; Ti, titanium; V, vanadium; Cr, chromium; Mn, manganese; Fe, iron; Co, cobalt; Ni, nickel; Cu, copper; Zn, zinc; Ga, gallium; Ge, germanium; As, arsenic; Se, selenium; Rb, rubidium; Sr, strontium; Y, yttrium; Zr, zirconium; Nb, niobium; Mo, molybdenum; Cd, cadmium; Sb, antimony; Cs, cesium; Ba, barium; La, lanthanum; Ce, cerium; Tl, thallium; $\mathrm{Pb}$, lead; Bi, bismuth; Th, thorium; U, uranium; \% Difference, the difference between the certified (true) and reported value (or average of reported values) divided by the certified value and expressed as percent; Avg. Abs. Diff., the average of the absolute values of \% Difference for all analytes for one standard reference sample; Grand Avg. Abs. Diff., the average of the absolute values of \% Difference for all analytes and all standard reference samples; Relative \% Diff., the difference between replicate analyses divided by the average of the analyses and expressed as percent; Grand Avg. Precision, the average of Relative \% Diff. for all analytes and all replicate samples]

\begin{tabular}{|c|c|c|c|c|c|c|c|c|c|}
\hline $\begin{array}{c}\text { QC sample, statistic, } \\
\text { and(or) date }\end{array}$ & $\begin{array}{c}\mathrm{Fe} \\
(\mu \mathrm{g} / \mathrm{L})\end{array}$ & $\begin{array}{c}\text { Co } \\
(\mu \mathrm{g} / \mathrm{L})\end{array}$ & $\begin{array}{c}\mathbf{N i} \\
(\mu \mathrm{g} / \mathrm{L})\end{array}$ & $\begin{array}{c}\mathrm{Cu} \\
(\mu \mathrm{g} / \mathrm{L})\end{array}$ & $\begin{array}{c}\mathrm{Zn} \\
(\mu \mathrm{g} / \mathrm{L})\end{array}$ & $\begin{array}{c}\mathbf{G a} \\
(\mu \mathbf{g} / \mathbf{L})\end{array}$ & $\begin{array}{c}\mathbf{G e} \\
(\mu \mathrm{g} / \mathrm{L})\end{array}$ & $\begin{array}{c}\text { As } \\
(\mu \mathrm{g} / \mathrm{L})\end{array}$ & $\begin{array}{c}\text { Se } \\
(\mu \mathrm{g} / \mathrm{L})\end{array}$ \\
\hline \multicolumn{10}{|l|}{ BIAS } \\
\hline $\begin{array}{l}\text { NIST-1643d true } \\
\% \text { Difference } \\
\text { Avg. Abs. Diff. }\end{array}$ & $\begin{array}{l}91.2 \\
20\end{array}$ & $\begin{array}{l}25 \\
-1\end{array}$ & $\begin{array}{l}58.1 \\
-4\end{array}$ & $\begin{array}{l}20.5 \\
-2\end{array}$ & $\begin{array}{l}72.5 \\
-6\end{array}$ & - & - & $\begin{array}{l}56 \\
-13\end{array}$ & $\begin{array}{l}11.4 \\
-8\end{array}$ \\
\hline $\begin{array}{l}\text { T-161 true } \\
\% \text { Difference } \\
\text { Avg. Abs. Diff. }\end{array}$ & $\begin{array}{l}61.7 \\
-4\end{array}$ & $\begin{array}{l}12.5 \\
-2\end{array}$ & $\begin{array}{l}29.0 \\
0\end{array}$ & $\begin{array}{l}22.0 \\
0\end{array}$ & $\begin{array}{l}40.6 \\
11\end{array}$ & - & - & $\begin{array}{l}26.1 \\
-5\end{array}$ & $\begin{array}{l}9.58 \\
10\end{array}$ \\
\hline $\begin{array}{l}\text { T-147 true } \\
\% \text { Difference } \\
\text { Avg. Abs. Diff. }\end{array}$ & $\begin{array}{l}8.4 \\
-\end{array}$ & - & $\begin{array}{l}13.6 \\
-9\end{array}$ & $\begin{array}{l}11.4 \\
1\end{array}$ & $\begin{array}{l}14.0 \\
3\end{array}$ & $\begin{array}{l}- \\
-\end{array}$ & - & $\begin{array}{l}2.39 \\
-16\end{array}$ & $\begin{array}{l}10.1 \\
11\end{array}$ \\
\hline Grand Avg. Abs. Diff. & & & & & & & & & \\
\hline PRECISION, FIELD REPLIC & & & & & & & & & \\
\hline $\begin{array}{l}\text { SCS-1A, 12/6/03 } \\
\text { SCS-1B, 12/6/03 } \\
\text { Relative \% Diff. }\end{array}$ & $\begin{array}{l}<50 \\
<50 \\
-\end{array}$ & $\begin{array}{l}0.07 \\
0.07 \\
0\end{array}$ & $\begin{array}{l}<0.4 \\
<0.4 \\
-\end{array}$ & $\begin{array}{l}1.4 \\
1.4 \\
0\end{array}$ & $\begin{array}{l}- \\
- \\
-\end{array}$ & $\begin{array}{l}- \\
- \\
-\end{array}$ & $\begin{array}{l}<0.05 \\
<0.05 \\
-\end{array}$ & $\begin{array}{l}<1 \\
<1 \\
-\end{array}$ & $\begin{array}{l}6.8 \\
6.8 \\
0\end{array}$ \\
\hline $\begin{array}{l}\text { TGS-1A, 12/6/03 } \\
\text { TGS-1B, 12/6/03 } \\
\text { Relative \% Diff. }\end{array}$ & $\begin{array}{l}<50 \\
<50 \\
-\end{array}$ & $\begin{array}{l}0.99 \\
0.98 \\
1\end{array}$ & $\begin{array}{l}<0.4 \\
<0.4 \\
-\end{array}$ & $\begin{array}{l}3.9 \\
4 \\
3\end{array}$ & $\begin{array}{l}- \\
- \\
-\end{array}$ & $\begin{array}{l}- \\
- \\
-\end{array}$ & $\begin{array}{l}<0.05 \\
<0.05 \\
-\end{array}$ & $\begin{array}{l}2 \\
2 \\
0\end{array}$ & $\begin{array}{l}36.8 \\
38.1 \\
3\end{array}$ \\
\hline $\begin{array}{l}\text { WTGS-2A, 12/6/03 } \\
\text { WTGS-2B, 12/6/03 }\end{array}$ & $\begin{array}{l}<50 \\
50\end{array}$ & $\begin{array}{l}0.73 \\
0.77\end{array}$ & $\begin{array}{l}<0.4 \\
<0.4\end{array}$ & $\begin{array}{l}3 \\
3.2\end{array}$ & - & - & $\begin{array}{l}<0.05 \\
<0.05\end{array}$ & $\begin{array}{l}1 \\
1\end{array}$ & $\begin{array}{l}34.6 \\
36.6\end{array}$ \\
\hline Relative \% Diff. & - & 5 & - & 6 & - & - & - & 0 & 6 \\
\hline
\end{tabular}

Grand Avg. Abs. Diff. 
Table A2. Analytical quality-assurance and quality-control data for Toll Gate Creek water samples. —Continued

[ $\mu \mathrm{g} / \mathrm{L}$, microgram per liter; mg/L, microgram per liter; Dec., December; Mar., March; QC, Quality control; NIST, National Institute of Standards and Technology; \%, percent; <, less than; -, no value; A and B suffix on sample names indicate different replicate samples; Li, lithium; Be, beryllium, $\mathrm{Na}$, sodium; Mg, magnesium; Al, aluminum; Si, silicon; P, phosphorus; $\mathrm{SO}_{4}$, sulfate; $\mathrm{K}$, potassium; $\mathrm{Ca}$, calcium; $\mathrm{Sc}$, scandium; Ti, titanium; $\mathrm{V}$, vanadium; Cr, chromium; Mn, manganese; Fe, iron; $\mathrm{Co}$, cobalt; $\mathrm{Ni}$, nickel; $\mathrm{Cu}$, copper; $\mathrm{Zn}$, zinc; Ga, gallium; Ge, germanium; As, arsenic; Se, selenium; Rb, rubidium; Sr, strontium; Y, yttrium; Zr, zirconium; Nb, niobium; Mo, molybdenum; Cd, cadmium; Sb, antimony; Cs, cesium; Ba, barium; La, lanthanum; Ce, cerium; Tl, thallium; Pb, lead; Bi, bismuth; Th, thorium; U, uranium; \% Difference, the difference between the certified (true) and reported value (or average of reported values) divided by the certified value and expressed as percent; Avg. Abs. Diff., the average of the absolute values of \% Difference for all analytes for one standard reference sample; Grand Avg. Abs. Diff., the average of the absolute values of \% Difference for all analytes and all standard reference samples; Relative $\%$ Diff., the difference between replicate analyses divided by the average of the analyses and expressed as percent; Grand Avg. Precision, the average of Relative \% Diff. for all analytes and all replicate samples]

\begin{tabular}{|c|c|c|c|c|c|c|c|c|}
\hline $\begin{array}{c}\text { QC sample, statistic, } \\
\text { and(or) date }\end{array}$ & $\begin{array}{c}\mathbf{R b} \\
(\mu \mathbf{g} / \mathbf{L})\end{array}$ & $\begin{array}{c}\mathrm{Sr} \\
(\mu \mathrm{g} / \mathrm{L})\end{array}$ & $\begin{array}{c}\mathbf{Y} \\
(\mu \mathbf{g} / \mathbf{L})\end{array}$ & $\begin{array}{c}\mathrm{Zr} \\
(\mu \mathrm{g} / \mathrm{L})\end{array}$ & $\begin{array}{c}\mathrm{Nb} \\
(\mu \mathrm{g} / \mathrm{L})\end{array}$ & $\begin{array}{c}\text { Mo } \\
(\mu \mathrm{g} / \mathrm{L})\end{array}$ & $\begin{array}{c}\text { Cd } \\
(\mu \mathrm{g} / \mathrm{L})\end{array}$ & $\begin{array}{c}\text { Sb } \\
(\mu \mathbf{g} / \mathbf{L})\end{array}$ \\
\hline \multicolumn{9}{|l|}{ BIAS } \\
\hline $\begin{array}{l}\text { Lower Limit of Detection } \\
18 \text { meg-ohm deionized water wash, all }\end{array}$ & $<0.01$ & $<0.5$ & $<0.01$ & $<0.2$ & $<0.2$ & $<2$ & $<0.02$ & $<0.3$ \\
\hline sample runs & $<0.01$ & $<0.5$ & $<0.01$ & $<0.2$ & $<0.2$ & $<2$ & $<0.02$ & $<0.3$ \\
\hline \multicolumn{9}{|l|}{ Dec. 16/17, 2003 QC Samples } \\
\hline NIST-1643d QC standard & 11.9 & 302 & $<0.01$ & $<0.2$ & 0.26 & 122 & 6.23 & 56.2 \\
\hline Procedural Field Blank 12/16 & $<0.01$ & $<0.5$ & $<0.01$ & $<0.2$ & $<0.2$ & $<2$ & $<0.02$ & $<0.3$ \\
\hline Procedural Field Blank 12/17 & $<0.01$ & $<0.5$ & $<0.01$ & $<0.2$ & $<0.2$ & $<2$ & $<0.02$ & $<0.3$ \\
\hline NIST-1643d QC standard & 12.5 & 308 & $<0.01$ & $<0.2$ & $<0.2$ & 122 & 6.33 & 56.7 \\
\hline \multicolumn{9}{|l|}{ QC Summary: } \\
\hline NIST-1643d true & 13 & 295 & - & - & - & 113 & 6.47 & 54.1 \\
\hline$\%$ Difference & -6 & 3 & - & - & - & 8 & -3 & 4 \\
\hline \multicolumn{9}{|l|}{ Avg. Abs. Diff. } \\
\hline \multicolumn{9}{|l|}{ Mar. 2, 2004 QC Samples } \\
\hline NIST-1643d & 11.4 & 290 & $<0.01$ & $<0.2$ & 0.22 & 116 & 5.87 & 50.8 \\
\hline $\mathrm{T}-161$ & 0.37 & 50.5 & 0.15 & $<0.2$ & $<0.2$ & 18.4 & 17.5 & 13 \\
\hline $\mathrm{T}-147$ & 2.09 & 298 & 0.06 & $<0.2$ & $<0.2$ & 12.3 & 15.4 & 9.61 \\
\hline Procedural Field Blank & $<0.01$ & 1.39 & $<0.01$ & $<0.2$ & 0.99 & $<2$ & $<0.02$ & $<0.3$ \\
\hline NIST-1643d & 11.4 & 290 & $<0.01$ & $<0.2$ & $<0.2$ & 114 & 5.89 & 50.2 \\
\hline $\mathrm{T}-161$ & 0.37 & 51.2 & 0.14 & $<0.2$ & $<0.2$ & 18.5 & 17.7 & 13.2 \\
\hline $\mathrm{T}-147$ & 2.08 & 299 & 0.06 & $<0.2$ & $<0.2$ & 12.1 & 15.4 & 9.57 \\
\hline
\end{tabular}


[ $\mu \mathrm{g} / \mathrm{L}$, microgram per liter; mg/L, microgram per liter; Dec., December; Mar., March; QC, Quality control; NIST, National Institute of Standards and Technology; \%, percent; <, less than; -, no value; A and B suffix on sample names indicate different replicate samples; $\mathrm{Li}$, lithium; Be, beryllium, $\mathrm{Na}$, sodium; Mg, magnesium; Al, aluminum; $\mathrm{Si}$, silicon; P, phosphorus; $\mathrm{SO}_{4}$, sulfate; $\mathrm{K}$, potassium; $\mathrm{Ca}$, calcium; $\mathrm{Sc}$, scandium; Ti, titanium; $\mathrm{V}$, vanadium; $\mathrm{Cr}$, chromium; Mn, manganese; $\mathrm{Fe}$, iron; $\mathrm{Co}$, cobalt; $\mathrm{Ni}$, nickel; $\mathrm{Cu}$, copper; $\mathrm{Zn}$, zinc; Ga, gallium; Ge, germanium; As, arsenic; Se, selenium; Rb, rubidium; Sr, strontium; Y, yttrium; Zr, zirconium; Nb, niobium; Mo, molybdenum; Cd, cadmium; Sb, antimony; $\mathrm{Cs}$, cesium; Ba, barium; La, lanthanum; Ce, cerium; Tl, thallium; Pb, lead; Bi, bismuth; Th, thorium; U, uranium; \% Difference, the difference between the certified (true) and reported value (or average of reported values) divided by the certified value and expressed as percent; Avg. Abs. Diff., the average of the absolute values of \% Difference for all analytes for one standard reference sample; Grand Avg. Abs. Diff., the average of the absolute values of \% Difference for all analytes and all standard reference samples; Relative $\%$ Diff., the difference between replicate analyses divided by the average of the analyses and expressed as percent; Grand Avg. Precision, the average of Relative \% Diff. for all analytes and all replicate samples]

\begin{tabular}{|c|c|c|c|c|c|c|c|c|}
\hline $\begin{array}{c}\text { QC sample, statistic, } \\
\text { and(or) date }\end{array}$ & $\begin{array}{c}\mathbf{R b} \\
(\mu \mathbf{g} / \mathbf{L})\end{array}$ & $\begin{array}{c}\mathrm{Sr} \\
(\mu \mathrm{g} / \mathrm{L})\end{array}$ & $\begin{array}{c}\mathbf{Y} \\
(\mu \mathrm{g} / \mathrm{L})\end{array}$ & $\begin{array}{c}\mathrm{Zr} \\
(\mu \mathrm{g} / \mathrm{L})\end{array}$ & $\begin{array}{c}\mathbf{N b} \\
(\mu \mathrm{g} / \mathrm{L})\end{array}$ & $\begin{array}{c}\text { Mo } \\
(\mu \mathrm{g} / \mathrm{L})\end{array}$ & $\begin{array}{c}\text { Cd } \\
(\mu \mathrm{g} / \mathrm{L})\end{array}$ & $\begin{array}{c}\text { Sb } \\
(\mu \mathrm{g} / \mathrm{L})\end{array}$ \\
\hline \multicolumn{9}{|l|}{ BIAS } \\
\hline \multicolumn{9}{|l|}{ QC Summary: } \\
\hline NIST-1643d true & 13 & 295 & - & - & - & 113 & 6.47 & 54.1 \\
\hline$\%$ Difference & -12 & -2 & - & - & - & 2 & -9 & -7 \\
\hline \multicolumn{9}{|l|}{ Avg. Abs. Diff. } \\
\hline $\mathrm{T}-161$ true & - & 54.2 & - & - & - & 18.9 & 17.5 & 14.0 \\
\hline$\%$ Difference & - & -6 & - & - & - & -2 & 1 & -6 \\
\hline \multicolumn{9}{|l|}{ Avg. Abs. Diff. } \\
\hline $\mathrm{T}-147$ true & - & 313 & - & - & - & 11.8 & 15.9 & 10.5 \\
\hline$\%$ Difference & - & -5 & - & - & - & 3 & -3 & -9 \\
\hline \multicolumn{9}{|l|}{ Avg. Abs. Diff. } \\
\hline \multicolumn{9}{|l|}{ Grand Avg. Abs. Diff. } \\
\hline \multicolumn{9}{|c|}{ PRECISION, FIELD REPLICATES } \\
\hline SCS-1A, 12/6/03 & 1.84 & 2,360 & 0.07 & $<0.2$ & 0.2 & 3.2 & $<0.02$ & $<0.3$ \\
\hline SCS-1B, $12 / 6 / 03$ & 1.69 & 2,370 & 0.06 & $<0.2$ & $<0.2$ & 3.1 & $<0.02$ & $<0.3$ \\
\hline Relative \% Diff. & 8 & 0.4 & 15 & - & - & 3 & - & - \\
\hline TGS-1A, 12/6/03 & 2.81 & 4,720 & 0.1 & 0.2 & 0.2 & 3.3 & 0.08 & 0.46 \\
\hline TGS-1B, 12/6/03 & 2.81 & 4,770 & 0.11 & 0.2 & $<0.2$ & 3.2 & 0.08 & 0.48 \\
\hline Relative \% Diff. & 0 & 1 & 10 & 0 & - & 3 & 0 & 4 \\
\hline WTGS-2A, 12/6/03 & 2.69 & 5,590 & 0.1 & 0.2 & $<0.2$ & 2.3 & 0.04 & $<0.3$ \\
\hline WTGS-2B, 12/6/03 & 2.69 & 5,610 & 0.1 & 0.2 & $<0.2$ & 2.2 & 0.05 & $<0.3$ \\
\hline Relative \% Diff. & 0 & 0.4 & 0 & 0 & - & 4 & 22 & - \\
\hline
\end{tabular}

Grand Avg. Abs. Diff. 
Table A2. Analytical quality-assurance and quality-control data for Toll Gate Creek water samples. —Continued

[ $\mu \mathrm{g} / \mathrm{L}$, microgram per liter; mg/L, microgram per liter; Dec., December; Mar., March; QC, Quality control; NIST, National Institute of Standards and Technology; \%, percent; <, less than; -, no value; $\mathrm{A}$ and $\mathrm{B}$ suffix on sample names indicate different replicate samples; $\mathrm{Li}$, lithium; $\mathrm{Be}$, beryllium, $\mathrm{Na}$, sodium; $\mathrm{Mg}$, magnesium; $\mathrm{Al}$, aluminum; $\mathrm{Si}$, silicon; $\mathrm{P}$, phosphorus; $\mathrm{SO}$, sulfate; $\mathrm{K}$, potassium; Ca, calcium; Sc, scandium; Ti, titanium; V, vanadium; Cr, chromium; Mn, manganese; Fe, iron; Co, cobalt; Ni, nickel; Cu, copper; Zn, zinc; Ga, gallium; Ge, germanium; As, arsenic; Se, selenium; Rb, rubidium; Sr, strontium; Y, yttrium; Zr, zirconium; Nb, niobium; Mo, molybdenum; Cd, cadmium; Sb, antimony; Cs, cesium; Ba, barium; La, lanthanum; Ce, cerium; Tl, thallium; $\mathrm{Pb}$, lead; $\mathrm{Bi}$, bismuth; Th, thorium; $\mathrm{U}$, uranium; \% Difference, the difference between the certified (true) and reported value (or average of reported values) divided by the certified value and expressed as percent; Avg. Abs. Diff., the average of the absolute values of \% Difference for all analytes for one standard reference sample; Grand Avg. Abs. Diff., the average of the absolute values of \% Difference for all analytes and all standard reference samples; Relative \% Diff., the difference between replicate analyses divided by the average of the analyses and expressed as percent; Grand Avg. Precision, the average of Relative \% Diff. for all analytes and all replicate samples]

\begin{tabular}{|c|c|c|c|c|c|c|c|c|c|}
\hline $\begin{array}{l}\text { OC sample, statistic, } \\
\text { and(or) date }\end{array}$ & $\begin{array}{c}\text { Cs } \\
(\mu \mathrm{g} / \mathrm{L})\end{array}$ & $\begin{array}{c}\text { Ba } \\
(\mu \mathbf{g} / \mathbf{L})\end{array}$ & $\begin{array}{c}\text { La } \\
(\mu \mathrm{g} / \mathrm{L})\end{array}$ & $\begin{array}{c}\text { Ce } \\
(\mu \mathrm{g} / \mathrm{L})\end{array}$ & $\begin{array}{c}\mathrm{TI} \\
(\mu \mathrm{g} / \mathrm{L})\end{array}$ & $\begin{array}{c}\mathbf{P b} \\
(\mu \mathrm{g} / \mathrm{L})\end{array}$ & $\begin{array}{c}\mathbf{B i} \\
(\mu \mathrm{g} / \mathrm{L})\end{array}$ & $\begin{array}{c}\text { Th } \\
(\mu \mathrm{g} / \mathrm{L})\end{array}$ & $\begin{array}{c}\mathbf{U} \\
(\mu \mathrm{g} / \mathrm{L})\end{array}$ \\
\hline \multicolumn{10}{|l|}{ BIAS } \\
\hline $\begin{array}{l}\text { Lower Limit of Detection } \\
18 \text { meg-ohm deionized water wash, all }\end{array}$ & $<0.02$ & $<0.2$ & $<0.01$ & $<0.01$ & $<0.1$ & $<0.05$ & $<0.2$ & $<0.2$ & $<0.1$ \\
\hline sample runs & $<0.02$ & $<0.2$ & $<0.01$ & $<0.01$ & $<0.1$ & $<0.05$ & $<0.2$ & $<0.2$ & $<0.1$ \\
\hline \multicolumn{10}{|l|}{ Dec. 16/17, 2003 QC Samples } \\
\hline NIST-1643d QC standard & 4.68 & 532 & 0.02 & 0.01 & 6.7 & 17 & 11.7 & $<0.2$ & $<0.1$ \\
\hline Procedural Field Blank 12/16 & $<0.02$ & $<0.2$ & $<0.01$ & $<0.01$ & $<0.1$ & $<0.05$ & $<0.2$ & $<0.2$ & 0.1 \\
\hline Procedural Field Blank 12/17 & $<0.02$ & $<0.2$ & $<0.01$ & $<0.01$ & $<0.1$ & $<0.05$ & $<0.2$ & $<0.2$ & 0.12 \\
\hline NIST-1643d QC standard & 4.63 & 529 & 0.02 & 0.01 & 6.9 & 16.9 & 11.3 & $<0.2$ & $<0.1$ \\
\hline \multicolumn{10}{|l|}{ QC Summary: } \\
\hline NIST-1643d true & - & 507 & - & - & 7.3 & 18.2 & - & - & - \\
\hline$\%$ Difference & - & 5 & - & - & -7 & -7 & - & - & - \\
\hline Avg. Abs. Diff. & & & & & & & & & \\
\hline \multicolumn{10}{|l|}{ Mar. 2, 2004 QC Samples } \\
\hline NIST-1643d & 4.32 & 504 & 0.02 & 0.01 & 6.3 & 16.2 & 11 & $<0.2$ & $<0.1$ \\
\hline $\mathrm{T}-161$ & $<0.02$ & 65.4 & 0.14 & 0.14 & 46.6 & 15.2 & $<0.2$ & $<0.2$ & 7.33 \\
\hline $\mathrm{T}-147$ & $<0.02$ & 67.3 & 0.04 & 0.05 & 18.1 & 12.5 & $<0.2$ & $<0.2$ & 2.9 \\
\hline Procedural Field Blank & $<0.02$ & $<0.2$ & $<0.01$ & $<0.01$ & 0.1 & $<0.05$ & $<0.2$ & $<0.2$ & $<0.1$ \\
\hline NIST-1643d & 4.19 & 487 & 0.02 & 0.01 & 6.3 & 16.9 & 10.9 & $<0.2$ & $<0.1$ \\
\hline $\mathrm{T}-161$ & $<0.02$ & 65.1 & 0.15 & 0.14 & 46.8 & 15.3 & $<0.2$ & $<0.2$ & 7.21 \\
\hline T-147 & $<0.02$ & 66.7 & 0.04 & 0.05 & 18.1 & 12.5 & $<0.2$ & $<0.2$ & 2.87 \\
\hline
\end{tabular}


[ $\mu \mathrm{g} / \mathrm{L}$, microgram per liter; mg/L, microgram per liter; Dec., December; Mar., March; QC, Quality control; NIST, National Institute of Standards and Technology; \%, percent; <, less than; -, no value; $\mathrm{A}$ and $\mathrm{B}$ suffix on sample names indicate different replicate samples; $\mathrm{Li}$, lithium; Be, beryllium, $\mathrm{Na}$, sodium; $\mathrm{Mg}$, magnesium; $\mathrm{Al}$, aluminum; $\mathrm{Si}$, silicon; $\mathrm{P}$, phosphorus; $\mathrm{SO}$, sulfate; $\mathrm{K}$,

potassium; Ca, calcium; Sc, scandium; Ti, titanium; V, vanadium; Cr, chromium; Mn, manganese; Fe, iron; Co, cobalt; Ni, nickel; Cu, copper; Zn, zinc; Ga, gallium; Ge, germanium; As, arsenic; Se, selenium; Rb, rubidium; Sr, strontium; Y, yttrium; Zr, zirconium; Nb, niobium; Mo, molybdenum; Cd, cadmium; Sb, antimony; Cs, cesium; Ba, barium; La, lanthanum; Ce, cerium; Tl, thallium; Pb, lead; Bi, bismuth; Th, thorium; U, uranium; \% Difference, the difference between the certified (true) and reported value (or average of reported values) divided by the certified value and expressed as percent; Avg. Abs. Diff., the average of the absolute values of \% Difference for all analytes for one standard reference sample; Grand Avg. Abs. Diff., the average of the absolute values of \% Difference for all analytes and all standard reference samples; Relative \% Diff., the difference between replicate analyses divided by the average of the analyses and expressed as percent; Grand Avg.

Precision, the average of Relative \% Diff. for all analytes and all replicate samples]

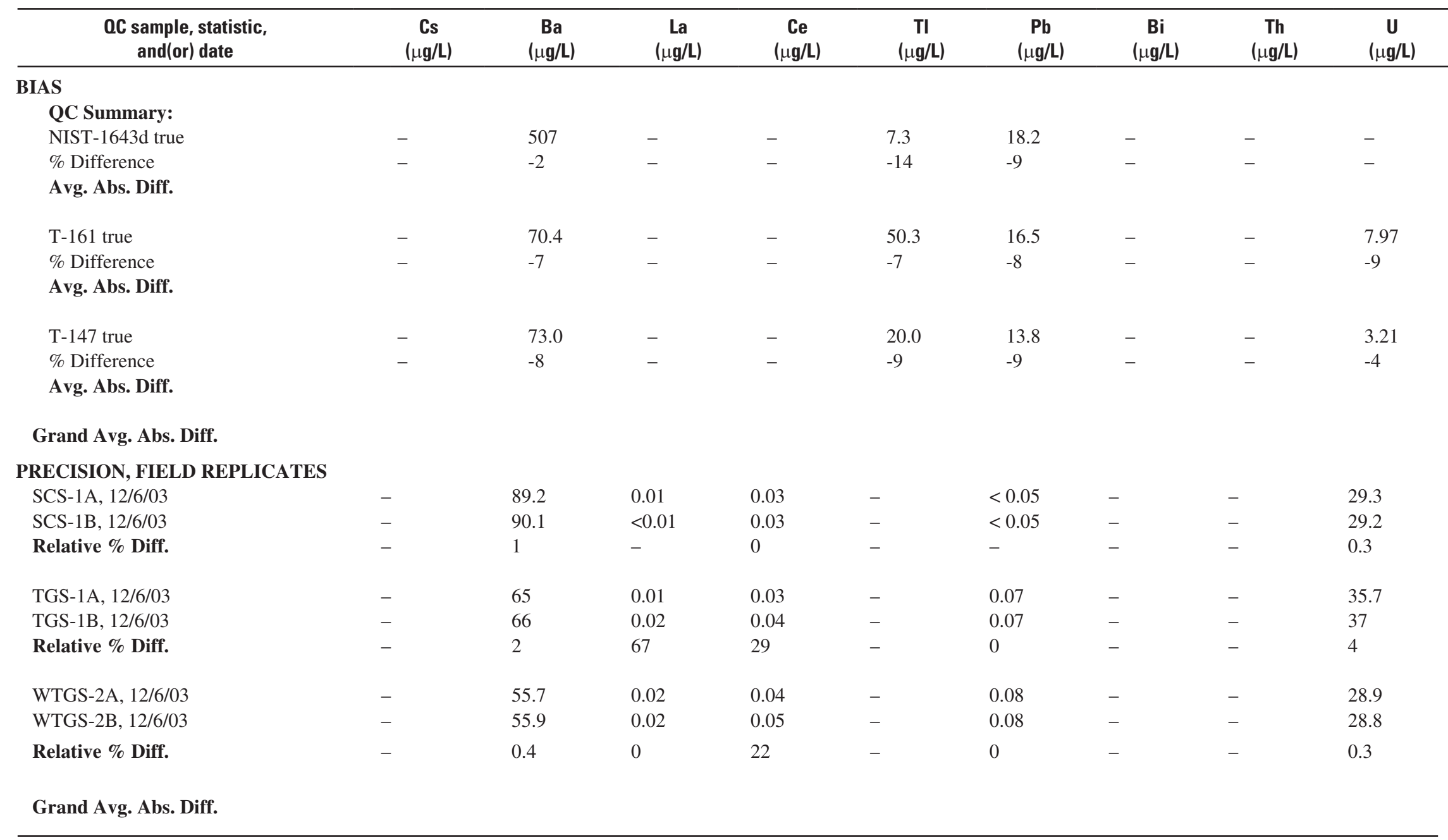




\section{APPENDIX B. Quality Assurance and Quality Control Procedural Details}


Bias was evaluated using percent difference (the difference between the certified and reported value (or average of reported values) divided by the certified value and expressed as percent for each certified element for a standard reference sample). This value generally was 10 percent or less for NIST-1634d for the December 2003 and March 2004 analyses except for Fe which was 20 percent or greater for each event. Percent-difference values for standard reference samples T147 and T-161 were generally less than 15 percent and did not validate the high Fe bias shown by NIST-1643d. The average of the absolute values of percent difference (Average Absolute Difference in table A2) for all elements for one standard reference sample estimates the overall bias. This value was between 5 and 8 percent for standard reference samples that were associated with environmental samples collected during December 2003 and March 2004 (table A2). Another estimate of overall bias is the grand average absolute difference (which is the average of the absolute values of percent difference for all elements for all standard reference samples) which was 6 percent for both sampling events (table A2). These results indicate that there is good control on bias, except possibly for Fe analyses.

For precision, the relative percent difference (the difference between replicate analyses divided by the average of the analyses and expressed as percent) for analysis of three laboratory replicates of samples from the December 2003 sampling event was \pm 5 percent, which indicates good precision for the samples collected and analyzed in December 2003 (table A2). Replicate analyses of NIST-1634d, T-147, and T-171 provided information to assess precision for the March 2004 samples. Relative percent difference was generally less than 5 percent for all elements (except in a few instances where the value was near the detection limit) and the average absolute difference for each reference material was less than 2 percent (raw data, but not relative percent difference calculations, are listed in table A2).

Element concentrations for the deionized water (DIW) blanks (wash) that accompanied ICP-MS analysis in the laboratory were all less than the detection limits. For the procedural field blank that used DIW from the same laboratory system, the concentrations of most elements were at or near the detection limits (table A2). However, zinc ( $\mathrm{Zn}$ ) was detected in the procedural blanks from December 16 and December 17, 2003, samples at concentrations of 50 and 68 micrograms per liter $(\mu \mathrm{g} / \mathrm{L})$. For several of the water samples collected on this date, the $\mathrm{Zn}$ concentration in the procedural blank was near to or exceeded $\mathrm{Zn}$ concentrations for the samples indicating possible $\mathrm{Zn}$ contamination in the environmental samples introduced by sample collection and processing. However, there were also several environmental samples that had much lower $\mathrm{Zn}$ concentrations than the procedural blank samples, which indicates that the contamination probably was not in the acid used to preserve the samples. Contamination may have been in the laboratory DIW used for the blank, or it may be random. The procedural blank for the March 2004 sampling event had a much lower Zn concentration (3.8 $\mu \mathrm{g} / \mathrm{L})$ indicating that $\mathrm{Zn}$ concentrations in the environmental samples probably were reliable. Because interpretation of $\mathrm{Zn}$ data was not a major part of this study, the possible contamination of environmental samples collected during December 2003 with $\mathrm{Zn}$ does not interfere with the interpretations presented herein.

The NIST 1643d standard was analyzed for qualityassurance/quality-control purposes with the two whole-water digestions. The percent difference between known and measured values ranged from 0 to 9 , and the average absolute percent difference for all elements was 1 percent indicating good control for theses analyses (these values are not listed in table A2).

The water-concentration data for Se in the duplicate site samples indicate that there was little to no variability at these sites during the sampling events. In addition, selenium results for the December sampling events 1 day apart show that there was little compositional variation at each site from day-to-day during base flow. 